Engineering Physics and Mathematics Division

\title{
CRITICALITY SAFETY STUDIES FOR THE STORAGE OF WASTE FROM NUCLEAR FUEL SERVICES IN INTERCELL STORAGE WELLS 2 AND 3 OF BUILDING 3019
}

\author{
R. T. Primm, III, C. M. Hopper, and G. R. Smolen
}

DATE PUBLISHED - November 1992

Research sponsored by the Office of Environmental Restoration and Waste Management

U.S. Department of Energy

Prepared by the

OAK RIDGE NATIONAL LABORATORY

Oak Ridge, Tennessee 37831 managed by

MARTIN MARIETTA ENERGY SYSTEMS, INC.

for the

U.S. DEPARTMENT OF ENERGY

under contract DE-AC05-840R21400 
TABLE OF CONTENTS

ACKNOWLEDGEMENTS $\ldots \ldots \ldots \ldots \ldots \ldots \ldots \ldots \ldots \ldots \ldots \ldots$

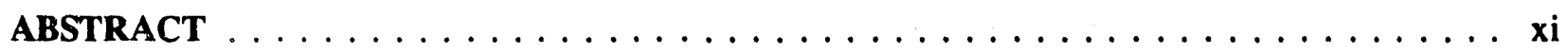

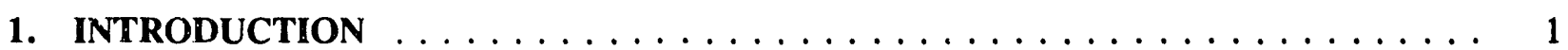

2. FACILITY DESCRIPTION $\ldots \ldots \ldots \ldots \ldots \ldots \ldots \ldots \ldots \ldots \ldots$

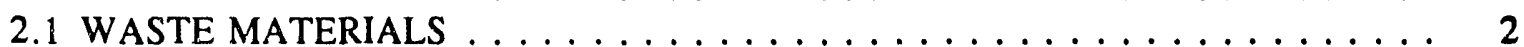

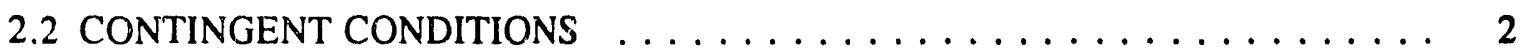

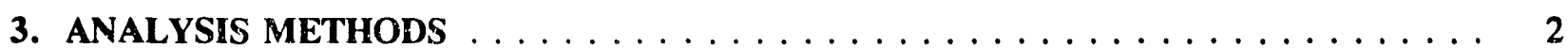

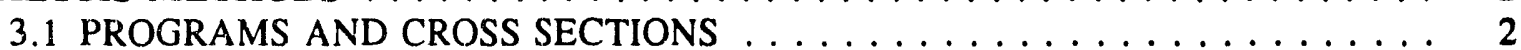

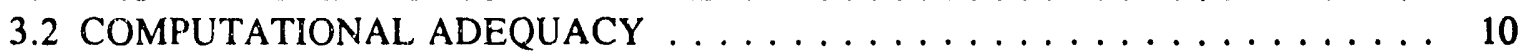

3.3 MARGINS OF SAFETY (COMPUTED SUBCRITICALITY) $\ldots \ldots \ldots \ldots \ldots$

4. COMPUTATIONS PERFORMED BY C. M. HOPPER (1985) $\ldots \ldots \ldots \ldots$

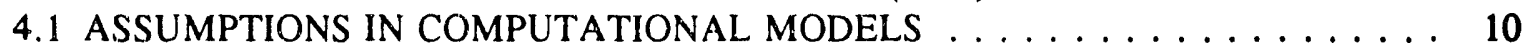

4.2 COMPUTATIONAL RESULTS $\ldots \ldots \ldots \ldots \ldots \ldots \ldots \ldots \ldots$

4.3 SUBCRITICAL LOAD LIMITS FOR SINGLE CONTAINERS $\ldots \ldots \ldots \ldots \ldots \ldots$

5. INVESTIGATION OF HOPPER CALCULATIONS $\ldots \ldots \ldots \ldots \ldots \ldots \ldots \ldots$

5.1 COMPUTATIONAL MODEL $\ldots \ldots \ldots \ldots \ldots \ldots \ldots \ldots \ldots$

5.2 VERIFICATION OF ASSUMPTIONS FOR SECTION 4 CALCULATIONS $\ldots \ldots$. 15

6. COMPUTATIONS AND SAFETY ANALYSES SPECIFIC TO NFS WASTE $\ldots \ldots \ldots$

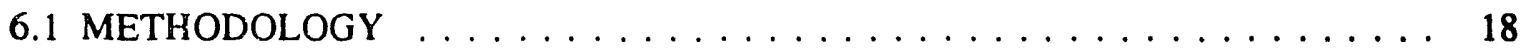

6.2 COMPUTATIONAL MODELS $\ldots \ldots \ldots \ldots \ldots \ldots \ldots \ldots \ldots \ldots$

6.3 RESULTS . . . . . . . . . . . . . . . . . . . . . . . . . 19

7. CONDITIONS FOR STORAGE WELL USE AND ASSIGNMENT OF SAFE

FISSILE MATERIAL LIMITS $\ldots \ldots \ldots \ldots \ldots \ldots \ldots \ldots \ldots \ldots \ldots$

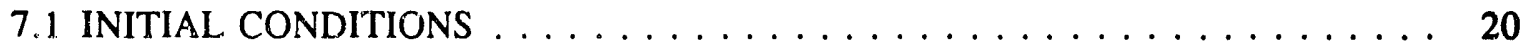

7.2 MATERIAL DEFINITION AND CONTAINMENT $\ldots \ldots \ldots \ldots \ldots \ldots \ldots$

7.3 FISSILE MATERIAL TRANSFERS TO, FROM, AND AMONG STORAGE

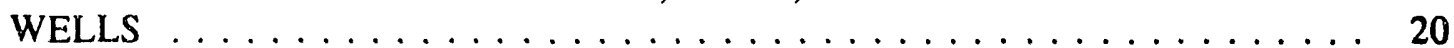

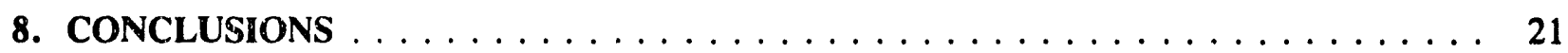

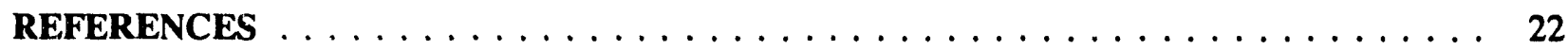


TABLE OF CONTENTS (continued)

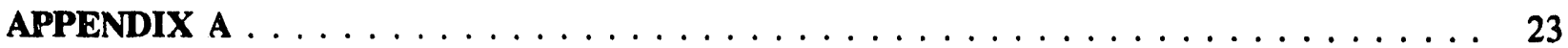

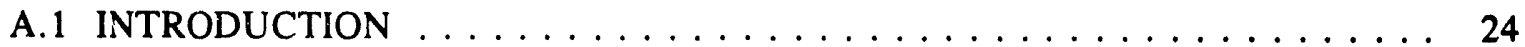

A.2 COMPUTATIONAL METHODS $\ldots \ldots \ldots \ldots \ldots \ldots \ldots \ldots \ldots$

A.3 CALCULATION OF K-EFFECTIVE FOR MIXED URANIUM AND

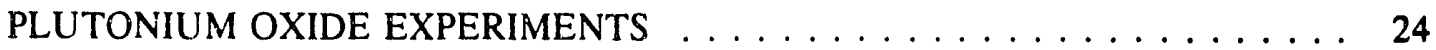

A.3.1 Unpoisoned Experiments with Little Moderation . . . . . . . . . . . . 24

A.3.2 Poisoned Experiments with Little Moderation . . . . . . . . . . . . . . 26

A.3.3 Unpoisoned, High-Moderation Mixed-Oxide Critical Experiments . . . . . . 29

A.4 INTERACTING ARRAY EXPERIMENTS $\ldots \ldots \ldots \ldots \ldots \ldots \ldots \ldots \ldots$

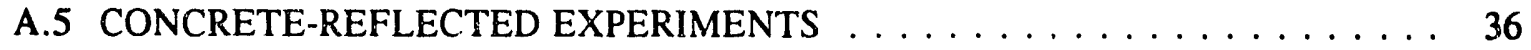

A.6 STATISTICAL ANALYSES OF CRITICAL EXPERIMENTS $\ldots \ldots \ldots \ldots \ldots$

A.7 CORRECTIONS TO DERIVED SUBCRICALITY LIMITS TO ACCOUNT FOR UNCERTAINTIES IN EXPERIMENTAL MEASUREMENTS . . . . . . . . 41

A.8 COMMENTS ON APPLICABILITY OF CRITICAL EXPERIMENTS AND

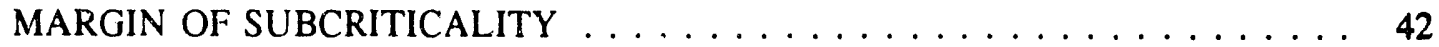

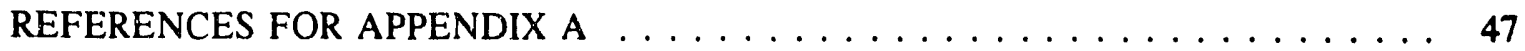

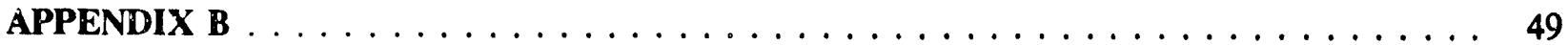

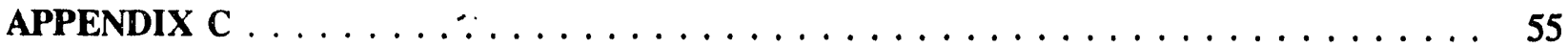

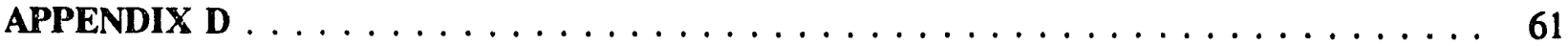

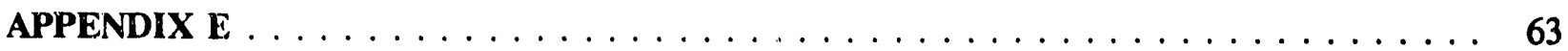

E.1 REACTIVITY AND PHYSICAL PARAMETERS OF THE WASTE

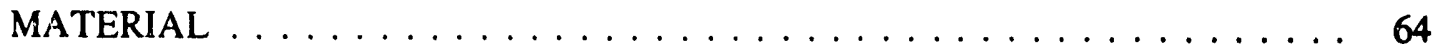

E.2 INTERPOLATIONS OF SUBCRITICAL FISSILE MATERIAL MASS

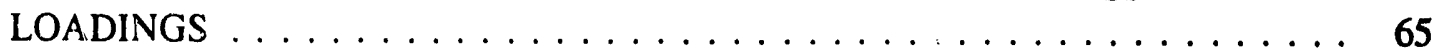

REFERENCES FOR APPENDIX E $\ldots \ldots \ldots \ldots \ldots \ldots \ldots$

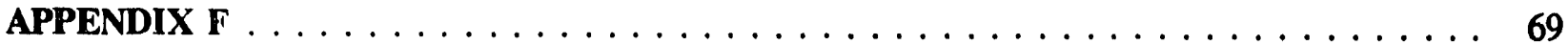




\section{LIST OF TABLES}

Table 1. NFS plutonium sources $\ldots \ldots \ldots \ldots \ldots \ldots \ldots$

Table 2. Summary of plutonium activity for fuels with greater than 80 wt $\%{ }^{239} \mathrm{Pu} \ldots \ldots$

Table 3. Summary of plutonium activity for fuels with less than 80 wt $\%{ }^{239} \mathrm{Pu} \ldots \ldots$

Table 4. Considered ${ }^{239} \mathrm{Pu}$ material characteristics $\ldots \ldots \ldots \ldots \ldots \ldots$

Table 5. Intercell 2 and $3{ }^{239}$ Pu results $\ldots \ldots \ldots \ldots \ldots \ldots \ldots$

Table 6. Maximum subcritical fully water reflected single infinite cylinders of ${ }^{239} \mathrm{Pu}$ metal . . 14

Table 7. Comparison of Intercell 2 and 3 calculations for ${ }^{239} \mathrm{Pu} \ldots \ldots \ldots \ldots$

Table 8. Atom densities in Barytes concrete $\ldots \ldots \ldots \ldots \ldots \ldots$

Table 9. Impact of concrete composition on calculated k-effective $\ldots \ldots \ldots$

Table 10. Reactivity parameters for abrormal intercell 2 ?nd 3 storage configurations . . . . 20

Table A.1. Description of experimental fuel and reflector for experiments $1453-01$ to $15 \ldots 25$

Table A.2. Critical assembly configurations for 29.3 wt $\% \mathrm{Pu}, 2.8 \mathrm{H}:(\mathrm{Pu}+\mathrm{U}), \mathrm{PuO}_{2}-\mathrm{UO}_{2}-$ polystryene fuel compacts $\ldots \ldots \ldots \ldots$

Table A.3. Reflected critical assembly configuration for 15 wt \% Pu, $2.86 \mathrm{H}:(\mathrm{Pu}+\mathrm{U})$,

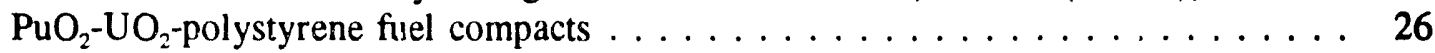

Table A.4. Calculated k-effectives for unpoisoned, low-moderation experiments . . . . . . 27

Table A.5. Description of experimental fuel and reflector material $\ldots \ldots \ldots \ldots$

Table A.6. Composition of neutron poison plates $\ldots \ldots \ldots \ldots$

Table A.7. Critical assembly configurations of poisoned, plexiglas-reflected $2.8 \mathrm{H}:(\mathrm{Pu}+\mathrm{U})$ mixed-oxide compacts . . . . . . . . . . . . . . . . . . . . . 29

Table A.8. Critical assembly configurations of poisoned, plexiglas-reflected $30.6 \mathrm{H}:(\mathrm{Pu}+\mathrm{U})$ mixed-oxide compacts . . . . . . . . . . . . . . . . . . 30

Table A.9. Calsilated $k$-effectives for poisoned, low-moderation experiments with

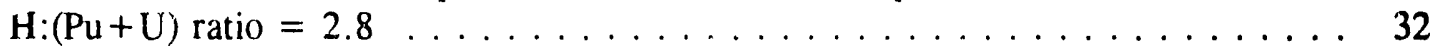

Table A.10. Calculated k-effectives for poisoned, low-moderation experiments with

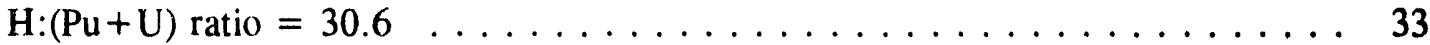




\section{LIST OF TABLES (continued)}

Table A.11. Composition and atom densities of fuels and reflector for high-moderation, mixed-oxide critical experiments . . . . . . . . . . . . . . . 34

Table A.12. Criticality data for mixed-oxide assemblies containing $30 \mathrm{wt} \% \mathrm{Pu}$ with $\mathrm{H}:(\mathrm{Pu}+\mathrm{U})=47.4 \ldots \ldots \ldots \ldots \ldots \ldots$

Table A.13. Criticality data for mixed-oxide assemblies containing $14.62 \mathrm{wt} \% \mathrm{Pu}$ with

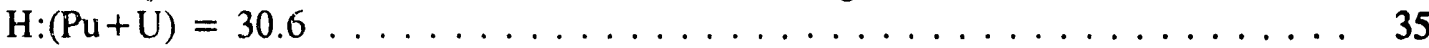

Table A.14. Calculated $k$-effectives for high-moderation, mixed-oxide critical experiments _ . . 35

Table A.15. Average calculated k-effectives for high-moderation mixed-oxide critical

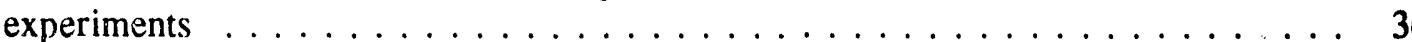

Table A.16. Experimental criticality data for concrete reflected type 3.2 FTR fuel pins in

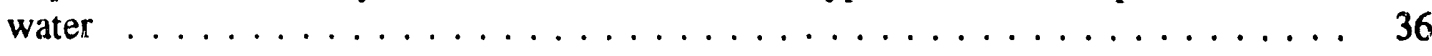

Table A.17. Comparison of concrete compositions $\ldots \ldots \ldots \ldots \ldots$

Table A.18. Calculated parameters for arrays of FTR pins $\ldots \ldots \ldots \ldots \ldots$

Table A.19. Categorized mean calculated k-effectives $\ldots \ldots \ldots \ldots \ldots$

Table A.20. Calculated Pearson product moment correlation coefficients for KENO-Va, Hansen-Roach calculations $\ldots \ldots \ldots \ldots \ldots \ldots \ldots \ldots$

Table A.21. Sources of experimental uncertainties $\ldots \ldots \ldots \ldots \ldots \ldots \ldots$

Table A.22. Reactivity worth of experimental uncertainties $\ldots \ldots \ldots \ldots \ldots$

Table E.1. Fitted constants of proportionality for ${ }^{239} \mathrm{Pu}$ in Intercell 2 and $3 \ldots \ldots 5$ 


\section{LIST OF FIGURES}

Fig. 1. Vertical inter-cells solid storage $\ldots \ldots \ldots \ldots \ldots \ldots \ldots$

Fig. 2. Intercell 2 and 3 storage wells $\ldots \ldots \ldots \ldots \ldots \ldots \ldots$

Fig. 3. Top view of cells 3,2 , and 1 (from left to right) $\ldots \ldots \ldots \ldots \ldots$

Fig. 4. Side view of cell $2 \ldots \ldots \ldots \ldots \ldots \ldots$

Fig. A.1. K-effectives from mixed-oxide criticals (KENO-Va, Hansen-Roach) . . . . . . . 40

Fig. A.2. Computed spectral comparison. Nominal case to critical experiments . . . . . . . 45

Fig. A.3. Calculated spectral comparison. Credible abnormal storage to critical experiment . . 46

Fig. C.1. Analyses of concrete walls in Building $3019 \ldots \ldots \ldots \ldots \ldots$

Fig. C.2. FORTRAN program to calculate atom densities for constituents of concrete . . . . . 59

Fig. C.3. Input to FORTRAN program to calculate concrete atom densities . . . . . . . . 60

Fig. C.4. Output from FORTRAN program to calculate concrete atom densities $\ldots \ldots \ldots$. . . 60

Fig. E.1. Deviation of fit value from calculated $k$-eff $\ldots \ldots \ldots \ldots 6$

Fig. E.2. Intercell 2 and $3{ }^{239} \mathrm{Pu}$ storage well loadings $\ldots \ldots \ldots \ldots \ldots$ 


\section{ACKNOWLEDGEMENTS}

Gratitude is expressed to J. C. Tuiner for his coding of the numerous cases from the 1985 studies. Also, thanks go to J. T. Thomas for his constructive comments and reviews of the 1985 results. R. M. Westfall and E. C. Crume, Jr. provided helpful reviews of this document. R. D. Lawson performed excellently in handling all publication aspects of this report. 


\begin{abstract}
This report provides computational evaluation results demonstrating that mixed oxide waste can be safely stored in Intercell Storage Wells 2 and 3 of Building 3019 at the Oak Ridge National Laboratory. Existing, verified computational techniques are validated with applicable critical experiments and tolerance limits for safety analyses are derived. Multiplication factors for normal and credible abnormal configurations are calculated and found to be far subcritical when compared to derived safety limits.
\end{abstract}




\title{
CRITICALITY SAFETY STUDIES FOR THE STORAGE OF WASTE FROM NUCLEAR FUEL SERVICES IN INTERCELL STORAGE WELLS 2 AND 3 OF BUILDING 3019
}

\author{
R. T. Primm, III, C. M. Hopper, and G. R. Smolen
}

\section{INTRODUCTION}

This report provides computational evaluation results demonstrating that waste materials described herein can be stored in Intercell Storage Wells 2 and 3 of Building 3019 with an acceptably low risk of inadvertent criticality. Normal and credible abnormal conditions for storage are identified. This report does not provide justification for the definitions of normal and credible abnormal conditions. Rather, the purpose of these studies is to show that calculations are valid when given a set of assumptions. Verified and validated computer programs and data libraries are used to determine that all identified configurations are safely subcritical.

A large number of previously unreferable calculations performed by $C$. M. Hopper are included in this document and thereby made referable. The assumptions upon which these prior analyses are based are examined via the use of verified/validated methods and the creation of new computational models. The calculations themselves are not repeated with the exception of a limited number of "spot" checks using new models. Instead, the methods and data are validated via the work documented in Ref. 1 and in Appendix A. An investigation of assumptions made by Hopper enables previously performed calculations to be referable provided allowances are made for assumptions made in the computational models. Criticality safety requirements derived as a result of these studies are stated, but should be used with caution and do not form the basis of the current evaluation.

The reader should note that this document provides evaluation results of a particular waste material ${ }^{2}$ for a particular storage location. At the time of the preparation of this document, work is under way on another document that would provide evaluations for a broader scope of fissile material operations. It is anticipated that, when completed, the broader, more comprehensive document will supersede this report as a reference for demonstrating subcriticality and criticality safety. This shorter, much more limited document is needed due to programmatic timetables.

\section{FACILITY DESCRIPTION}

According to A. M. Krichinsky, Chemical Technology Division, all Nuclear Fuel Services (NFS) waste material is to be stored in Intercell Storage 2 and 3 of Building 3019 except for that fraction that is to be shipped directly to a burial site. ${ }^{3}$ All of Intercell Storage 2 and 3 is currently empty. ${ }^{3}$ The reference description of Building 3019 is contained in Ref. 4, the "Final Safety Analysis Report for the Radiochemical Processing Plant" hereafter designated the FSAR. Figures 1 and 2 are Figs. 4.9 and 4.10, respectively, from the FSAR and show the configuration of the wells that makeup the Intercell Storage 2 and 3. Figures 3 and 4 are scaled drawings of cells 2 and 3. From these figures the dimensions are obtained that are used in the computational models described subsequently. Inspection of the actual installation was performed by one of the authors, and the documented geometry was confirmed.

The cell walls are believed to be composed of reinforced concrete. The measured concrete composition and derived atom densities are presented in Appendix C. Confirmation of the reinforcing steel content had not been obtained at the time of publication. All intercell storage wells have a 4 -in.-diam schedule- 
40 carbon steel pipe liner. The inside diameter of the liner is assumed to be 4.026 in. and the thickness of the pipe is 0.273 in.

\subsection{WASTE MATERIALS}

The actinide content of the waste material to be received from NFS is described in Tables 1 and $2 .{ }^{2}$ In most cases, the form of the waste material is oxide, ${ }^{2}$ but both powder and pellets are present. Some waste containers may contain plutonium metal. The total plutonium content in each shipping container is specified in Ref. 2 and will not exceed $260 \mathrm{~g}$. However, the uncertainty on the plutonium content is $\pm 25 \%$ (absolute, not 1 standard deviation) according to Ref. 2 . The container is a 2.75 -in.-diam by 6.403-in.-tall stainless steel vessel. The moisture content of the waste is specified to be less than 0.2 wt \% (uncertainty unknown). It is specified that the waste material shall contain no organic materials (uncertainty unknown).

Examining Tables 1, 2, and 3 it is seen that $92 \%$ of the plutonium processed at NFS is from the SEFOR batch, and this batch ias the highest percentage plutonium content $(20 \%)$. This material is the most reactive of the four batches and thus is the reference waste for the safety evaluations. However, for the calculations reported in subsequent sections, the plutonium was assumed to be $100 \%{ }^{239} \mathrm{Pu}$, rather than the isotopic mix shown in Table 2.

\subsection{CONTINGENT CONDITIONS}

Certain abnormal conditions regarding container integrity must be considered. Doubly loading a single can is evaluated. An increase in the moisture content of the oxide of up to a factor of five is considered (see Appendix D). The container radius is limited by the radius of the storage well and thus is not variable. The effect of waste distribution within a container is studied and will be reported in Section 4 .

A mechanism for water flooding of the wells is considered. Procedures specify that, at most, only two wells will be open at any given time. Flooding of either one, two, or all wells is considered. Leakage of water into the waste canisters is not considered a credible abnormal event (Appendix D). The effect of uncertain water composition in the cell wall concrete is evaluated.

\section{ANALYSIS METHODS}

Evaluations are based on standardized Monte Carlo calculational techniques. Confidence in accuracy is gained by comparison with previous computations by Primm, documented in Ref. 1 and by the validation calculations reported in Appendix A.

\subsection{PROGRAMS AND CROSS SECTIONS}

The nuclear criticality safety analyses of well storage under normal and credible abnormal conditions were performed with the multigroup Monte Carlo criticality program KENO-Va as embodied in the SCALE computational system. Hopper's work (Sect. 4) included some KENO-IV calculations as well as KENO-Va. All calculations were performed with the 16-energy-group cross sections identified as HANSEN-ROACH as provided within the SCALE system. For the current work, the versions of KENO-Va and SCALE used were those contained in the Martin Marietta Nuclear Criticality Safety Software (NCSS) ${ }^{6}$ procedure on the IBM-3090, unless noted otherwise. 


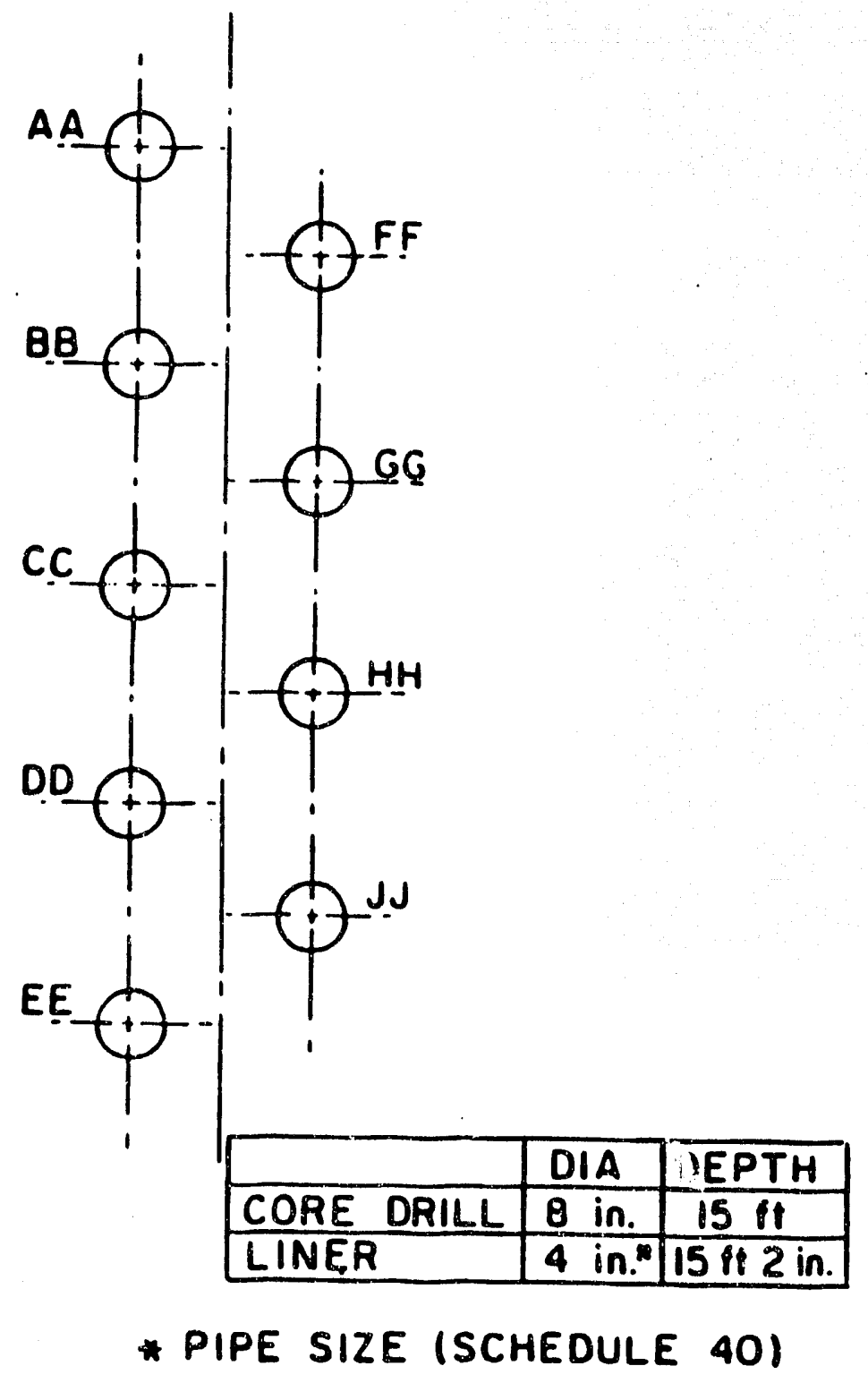

Fig. 1. Vertical inter-cells solid storage. 
2
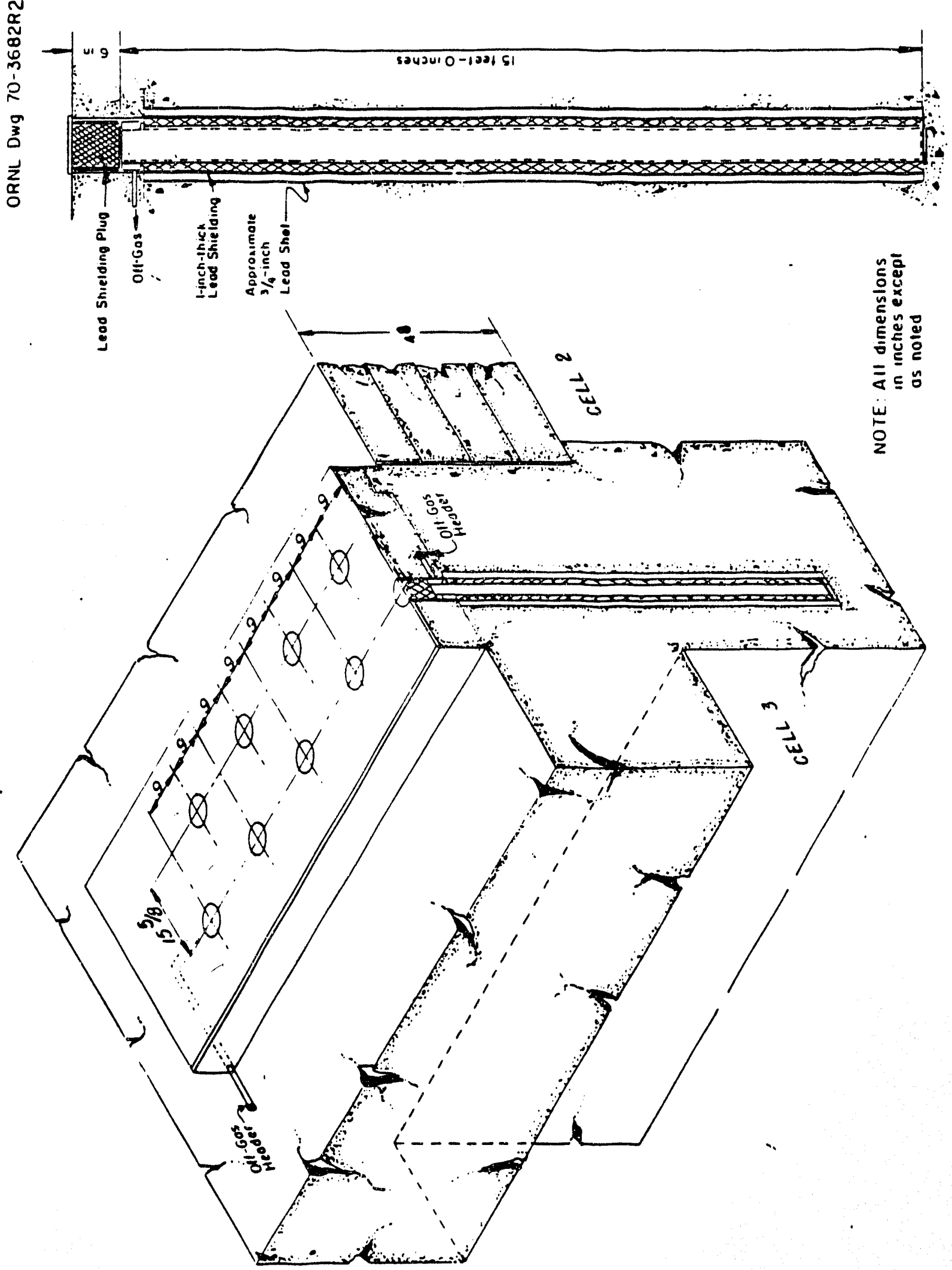

ن 


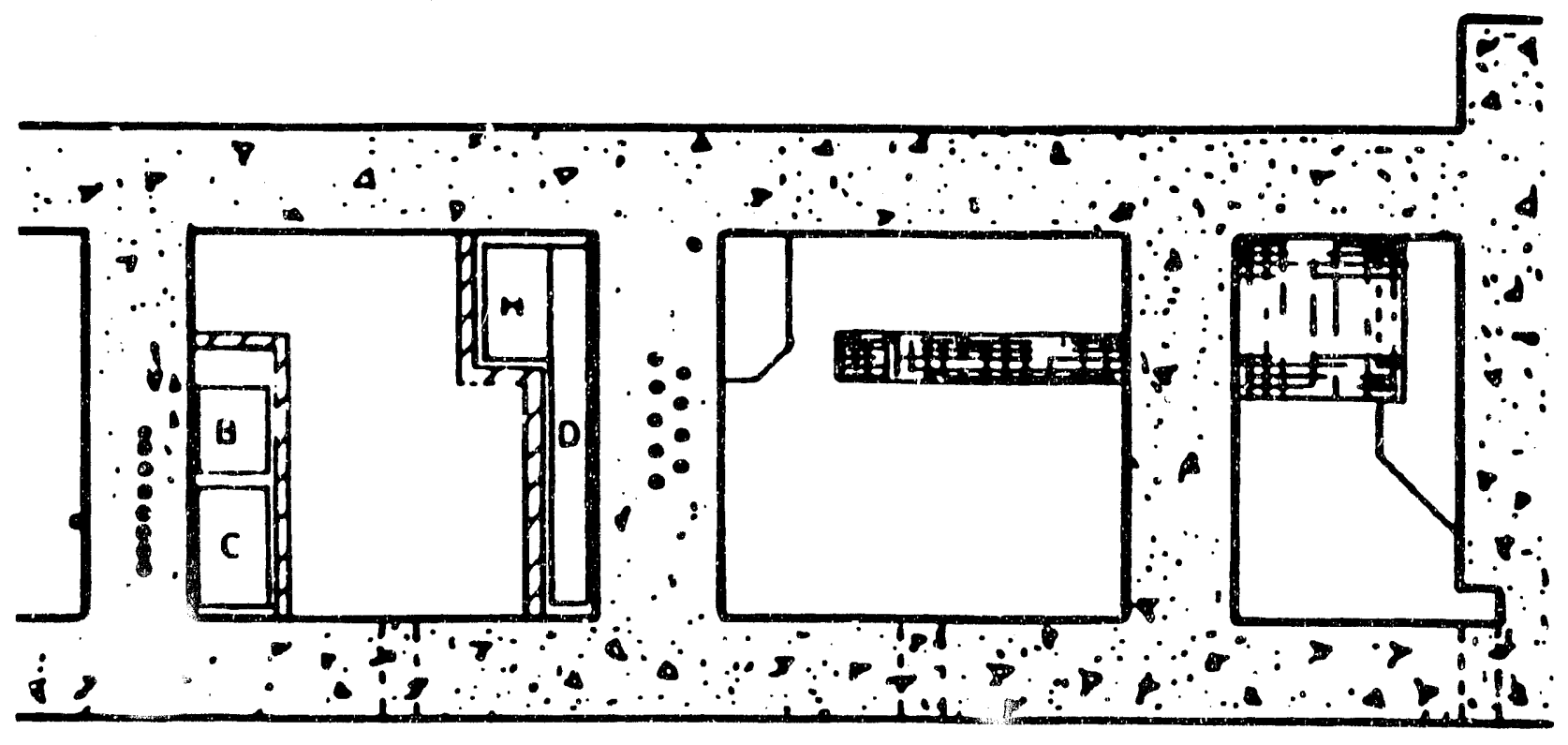

Scale: 1 in $=8.9 \mathrm{ft}$

Fig. 3. Top view of cells 3,2 , and 1 (from left to right). 


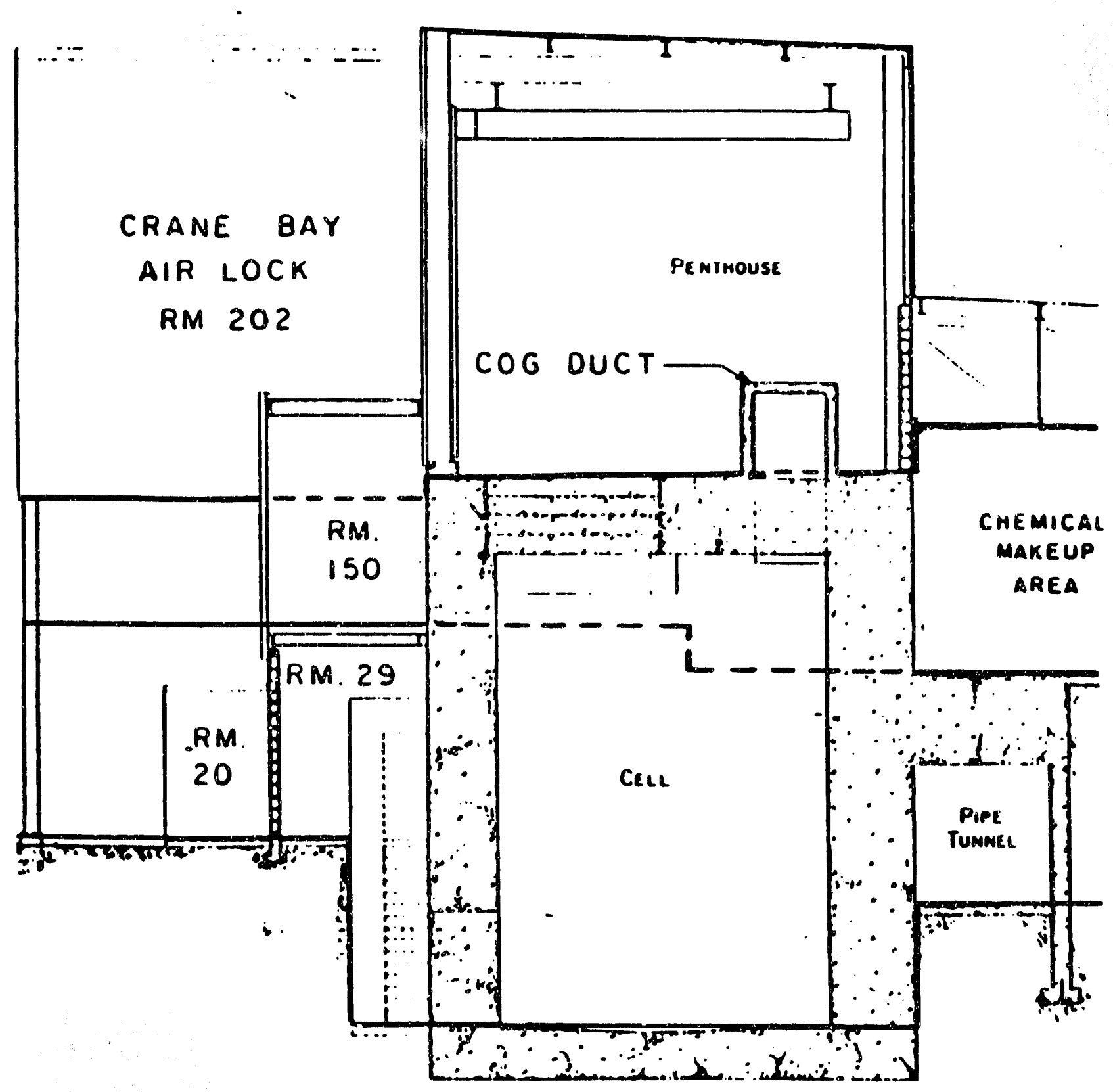

Scale: 1 in $=8.9 \mathrm{ft}$

Fig. 4. Side view of cell 2. 


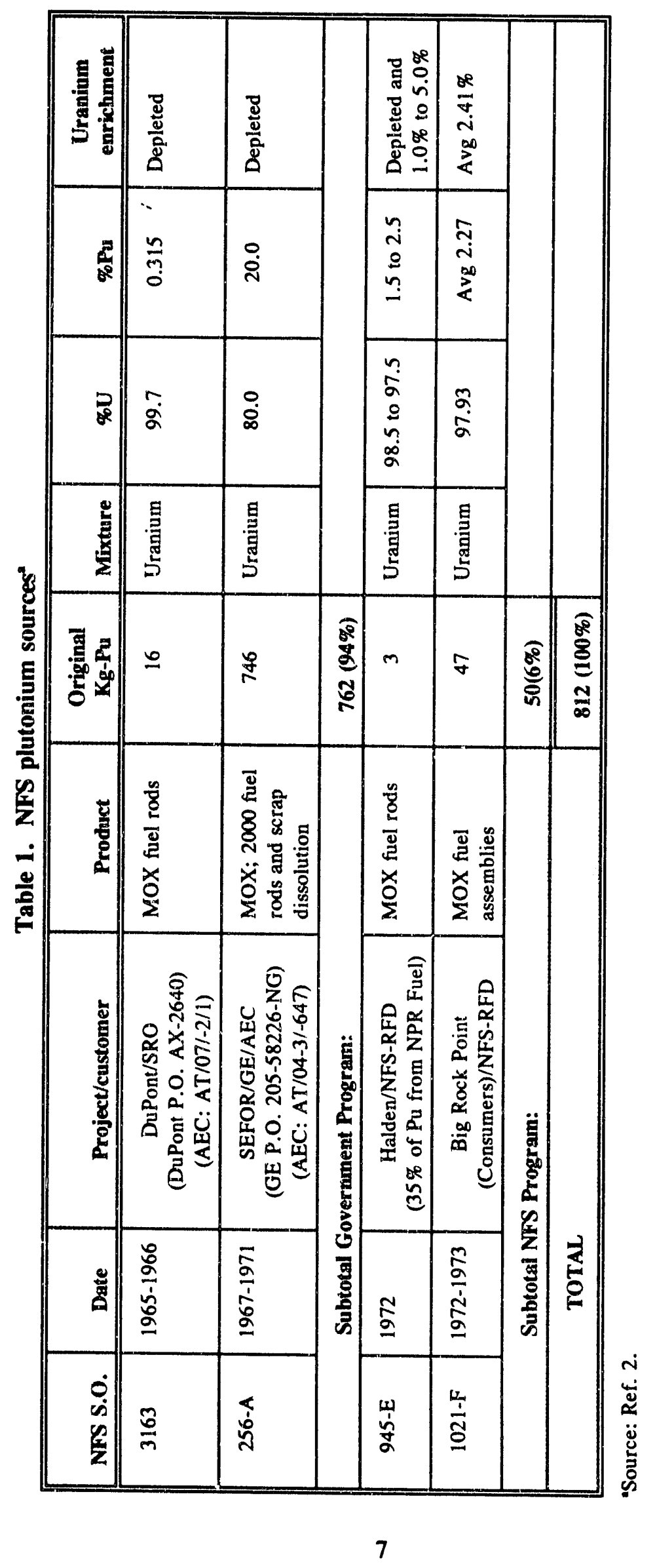


Table 2. Summary of plutonium activity for fuels with greater than $80 \mathrm{wt} \%{ }^{299} \mathrm{Pu}$

\begin{tabular}{|c|c|c|c|c|c|c|}
\hline \multicolumn{7}{|c|}{ SEFOR } \\
\hline Isotope & $\begin{array}{l}\text { Half-life } \\
\text { (days) }\end{array}$ & $\begin{array}{c}\mathrm{SpA} \\
(\mu \mathrm{Ci} / \mathrm{g})\end{array}$ & $\begin{array}{c}\text { Wt } \% \\
\text { Jan-70 }\end{array}$ & $\begin{array}{c}\mu \mathrm{Ci} / \mathrm{g} \\
\mathrm{Jan}_{\mathrm{an}-70}\end{array}$ & $\begin{array}{c}\mu \mathrm{Ci} / \mathrm{g} \\
\text { Aug-90 }\end{array}$ & $\begin{array}{c}\text { Wt } \% \\
\text { Aug-90 }\end{array}$ \\
\hline Pu-238 & $3.16 \mathrm{E}+04$ & $1.74 E+07$ & 0.036 & $6.26 \mathrm{E}+03$ & $5.31 \mathrm{E}+03$ & 0.0305 \\
\hline Pu-239 & $8.91 E+06$ & $6.13 E+04$ & 90.625 & $5.56 \mathrm{E}+04$ & $5.56 \mathrm{E}+04$ & 90.5720 \\
\hline Pu-240 & $2.40 \mathrm{E}+06$ & $2.26 \mathrm{E}+05$ & 8.334 & $1.89 E+04$ & $1.88 E+04$ & 8.3159 \\
\hline Pu-241 & $4.82 E+03$ & $1.12 \mathrm{E}+08$ & 0.477 & $5.36 \mathrm{E}+05$ & $1.82 \mathrm{E}+05$ & $0.161 ?$ \\
\hline Pu-242 & $1.38 \mathrm{E}+08$ & $3.90 \mathrm{E}+03$ & 0.052 & $2.03 E+00$ & $2.03 E+00$ & 0.0520 \\
\hline Am-241 & $1.67 \mathrm{E}+05$ & $3.24 \mathrm{E}+06$ & 0.467 & $1.51 \mathrm{E}+04$ & $2.47 \mathrm{E}+04$ & 0.7621 \\
\hline $\mathrm{SpA}$ & 07-Aug-90 & $\mu \mathrm{Ci} / \mathrm{g}$ & & & $\mathrm{Ci} / \mathrm{g}$ & $\mathrm{g} / \mathrm{Ci}$ \\
\hline Alpha: & & $1.04 \mathrm{E}+05$ & & & 0.10 & 9.58 \\
\hline Beta: & & $1.82 \mathrm{E}+05$ & & & 0.18 & 5.50 \\
\hline Alpha/Beta: & & $2.86 E+05$ & Ratio: & 0.57 & 0.29 & 3.49 \\
\hline \multicolumn{7}{|c|}{ WEST VALLEY (NPR) } \\
\hline Isotope & $\begin{array}{l}\text { Half-life } \\
\text { (days) }\end{array}$ & $\begin{array}{c}\mathrm{SpA} \\
(\mu \mathrm{Ci} / \mathrm{g})\end{array}$ & $\begin{array}{l}\text { Wi\% } \\
\text { Jan-70 }\end{array}$ & $\begin{array}{c}\mu \mathrm{Ci} / \mathrm{g} \\
\mathrm{Jan}-70\end{array}$ & $\begin{array}{c}\mu \mathrm{Ci} / \mathrm{g} \\
\text { Aug-90 }\end{array}$ & $\begin{array}{c}\text { Wt\% } \\
\text { Aug-90 }\end{array}$ \\
\hline Pu-238 & $3.16 \mathrm{E}+04$ & $1.74 \mathrm{E}+07$ & 0.079 & $1.37 \mathrm{E}+04$ & $1.16 \mathrm{E}+04$ & 0.0670 \\
\hline Pu-239 & $8.91 E+06$ & $6.13 E+04$ & 85.829 & $5.26 E+04$ & $5.26 \mathrm{E}+04$ & 85.7788 \\
\hline Pu-240 & $2.40 \mathrm{E}+06$ & $2.26 E+05$ & 11.531 & $2.61 E+04$ & $2.61 \mathrm{E}+04$ & 11.5060 \\
\hline Pu-241 & $4.82 E+03$ & $1.12 E+08$ & 1.156 & $1.30 \mathrm{E}+06$ & $4.41 E+05$ & 0.3919 \\
\hline Pu-242 & $1.38 \mathrm{E}+08$ & $3.90 \mathrm{E}+03$ & 0.25 & $9.75 E+00$ & $9.75 \mathrm{E}+00$ & 0.2500 \\
\hline Am-241 & $1.67 \mathrm{E}+05$ & $3.24 \mathrm{E}+06$ & 1.135 & $3.68 \mathrm{E}+04$ & $5.99 \mathrm{E}+04$ & 1.8500 \\
\hline SpA & 07-Aug-90 & & & & $\mathrm{Ci} / \mathrm{g}$ & $\mathrm{g} / \mathrm{Ci}$ \\
\hline Alpha: & & $1.50 \mathrm{E}+05$ & & & 0.15 & 6.66 \\
\hline Beta: & & $4.41 \mathrm{E}+05$ & & & 0.44 & 2.27 \\
\hline Alpha/Beta: & & $5.91 E+05$ & Ratio: & 0.34 & 0.59 & 1.69 \\
\hline
\end{tabular}


Table 3. Summary of plutonium activity for fuels with less than $80 \mathrm{wt} \%{ }^{20} \mathrm{Pu}$

\begin{tabular}{|c|c|c|c|c|c|c|}
\hline \multicolumn{7}{|c|}{ CONSUMERS POWER } \\
\hline Isotope & $\begin{array}{c}\text { Half-life } \\
\text { (days) }\end{array}$ & $\begin{array}{c}\mathrm{SpA} \\
(\mu \mathrm{Ci} / \mathrm{g})\end{array}$ & $\begin{array}{c}\text { Wt } \% \\
\text { Jan-70 }\end{array}$ & $\begin{array}{c}\mu \mathrm{Ci} / \mathrm{g} \\
\mathrm{Jan}-70 \\
\end{array}$ & $\begin{array}{c}\mu \mathrm{Ci} / \mathrm{g} \\
\text { Aug-90 } \\
\end{array}$ & $\begin{array}{c}\mathrm{Wt} \% \\
\text { Aug-90 }\end{array}$ \\
\hline Pu-238 & $3.16 \mathrm{E}+04$ & $1.74 \mathrm{E}+07$ & 0.425 & $7.39 E+04$ & $6.26 \mathrm{E}+04$ & 0.3603 \\
\hline Pu-239 & $8.91 \mathrm{E}+06$ & $6.13 \mathrm{E}+04$ & 76.241 & $4.68 E+04$ & $4.67 \mathrm{E}+04$ & 76.1964 \\
\hline $\mathrm{Pu}-240$ & $2.40 \mathrm{E}+06$ & $2.26 \mathrm{E}+05$ & 16.336 & $3.70 \mathrm{E}+04$ & $3.69 E+04$ & 16.3006 \\
\hline Pu-241 & $4.82 \mathrm{E}+03$ & $1.12 E+08$ & 2.91 & $3.27 E+06$ & $1.11 E+06$ & 0.9866 \\
\hline $\mathrm{Pu}-242$ & $1.38 \mathrm{E}+08$ & $3.90 \mathrm{E}+03$ & 1.17 & $4.56 \mathrm{E}+01$ & $4.56 \mathrm{E}+01$ & 1.1700 \\
\hline Am-241 & $1.67 \mathrm{E}+05$ & $3.24 \mathrm{E}+06$ & 2.857 & $9.26 \mathrm{E}+04$ & $1.51 \mathrm{E}+05$ & 4.6568 \\
\hline $\mathrm{SpA}$ & 07-Aug.90 & & & & $\mathrm{Ci} / \mathrm{g}$ & $\mathrm{g} / \mathrm{Ci}$ \\
\hline Alpha: & & $2.97 \mathrm{E}+05$ & & & 0.30 & 3.36 \\
\hline Beta: & & $1.11 \mathrm{E}+06$ & & & 1.11 & 0.90 \\
\hline Alpha/Beta: & & $1.41 \mathrm{E}+06$ & Ratio: & 0.27 & 1.41 & 0.71 \\
\hline \multicolumn{7}{|c|}{ HALDEN FUEL } \\
\hline Isotope & $\begin{array}{c}\text { Half-life } \\
\text { (days) }\end{array}$ & $\begin{array}{c}\mathrm{SpA} \\
(\mu \mathrm{Ci} / \mathrm{g})\end{array}$ & $\begin{array}{c}\text { Wt\% } \\
\text { Jan-70 }\end{array}$ & $\begin{array}{r}\mu \mathrm{Ci} / \mathrm{g} \\
\mathrm{Jan}-70 \\
\end{array}$ & $\begin{array}{c}\mu \mathrm{Ci} / \mathrm{g} \\
\text { Aug-90 } \\
\end{array}$ & $\begin{array}{c}\text { Wt } \% \\
\text { Aug-90 } \\
\end{array}$ \\
\hline $\mathrm{Pu}-238$ & $3.16 \mathrm{E}+04$ & $1.74 \mathrm{E}+07$ & 0.294 & $5.11 \mathrm{E}+04$ & $4.33 E+04$ & 0.2492 \\
\hline Pu-239 & $8.91 E+06$ & $6.13 E+04$ & 79.885 & $4.90 \mathrm{E}+04$ & $4.90 \mathrm{E}+04$ & 79.8382 \\
\hline Pu-240 & $2.40 \mathrm{E}+06$ & $2.26 \mathrm{E}+05$ & 14.509 & $3.29 \mathrm{E}+04$ & $3.28 \mathrm{E}+04$ & 14.4776 \\
\hline Pu-241 & $4.82 \mathrm{E}+03$ & $1.12 \mathrm{E}+08$ & 2.243 & $2.52 E+06$ & $8.55 \mathrm{E}+05$ & 0.7605 \\
\hline $\mathrm{Pu}-242$ & $1.38 \mathrm{E}+08$ & $3.90 E+03$ & 0.826 & $3.22 \mathrm{E}+01$ & $3.22 \mathrm{E}+01$ & 0.8260 \\
\hline Am-241 & $1.67 \mathrm{E}+05$ & $3.24 \mathrm{E}+06$ & 2.203 & $7.14 \mathrm{E}+04$ & $1.16 \mathrm{E}+05$ & 3.5902 \\
\hline $\mathrm{SpA}$ & 07-Aug-90 & & & & $\mathrm{Ci} / \mathrm{g}$ & $\mathrm{g} / \mathrm{Ci}$ \\
\hline Alpha: & & $2.41 E+05$ & & & 0.24 & 4.14 \\
\hline Beta: & & $8.55 E+05$ & & & 0.85 & 1.17 \\
\hline Alpha/Beta: & & $1.10 \mathrm{E}+06$ & Ratio: & 0.28 & 1.10 & 0.91 \\
\hline
\end{tabular}


The benchmark calculations in Appendix A were also performed with the 16-group cross-section library identified as HANSEN-ROACH inside the NCSS version of the SCALE system. The preparation of input data and selection of cross sections for use in the calculations were consistent with the methods outlined in the SCALE manuals. These same procedures were used in the preparation of input data for the Intercell 2 and 3 storage calculations described subsequently.

\subsection{COMPUTATIONAL ADEQUACY}

Verification of the equations solved by the computer programs that compose the modules of the SCALE-4 system has been discussed in Ref. 6 . A review of criticality safety literature revealed that considerable critical experiment data were available for mixed uranium-plutonium systems. Sixty-two critical configurations were identified which had $\mathrm{Pu} /(\mathrm{Pu}+\mathrm{U})$ ratios ranging from 15 to $30 \%$ (bounding the 20\% value noted in Table 1). h-effective values were calculated for all these experiments; these results are reported in Appendix A. The same experiments had been analyzed previously, ${ }^{1}$ albeit with earlier versions of codes and libraries. Excellent agreement between prior and current work was seen.

\subsection{MARGINS OF SAFETY (COMPUTED SUBCRITICALITY)}

For the work reported in the next section, Hopper assumed a computed value of k-effective plus 2 standard deviations of the result being less than 0.93 was sufficient to provide an adequate margin of subcriticality for calculated contingent conditions considered. Based on the results reported in Appendix A, this value was judged an adequate margin of subcriticality for the calculated conditions considered. This judgement was based on tolerance limits that have been corrected for experimental uncertainties (derived in Appendix A).

\section{COMPUTATIONS PERFORMED BY C. M. HOPPER (1985)}

\subsection{ASSUTIPTIONS IN COMPUTATIONAL MODELS}

The computer models reflected the storage configuration shown in Figs. 1 and 2, with a few exceptions. The concrete wall thicknesses in the model were on the order of $10 \mathrm{ft}$ instead of the actual 5 feet thickness (to approximate the effects of cell covers, incidental scattered reflectors in the cells, and other influences). The reactivity contributions of neutrons having migrated out to distances of $5 \mathrm{ft}$ to either side of the fissile material system and reentering the fissile material was considered to be negligible. In all cases, the concrete assumed for the calculations was that identified within the SCALE cross-section library as full-density Oak Ridge concrete. The lead shot surrounding the storage wells was assumed to have a packing fraction of 0.5 .

Because of the unknowns in package design and content, a parametric study formed the basis of the criticality safety assessment. Table 4 notes some of the conditions considered in this study.

The maximum material densities and their associated hydrogen-to-fissile isotope atom ratios are derived from volume displacements associated with theoretical densities of water and oxide.

\subsection{COMPUTATIONAL RESULTS}

Computations were performed to evaluate variations in fissile loading and moderator-to-heavy metal ratio. All calculations were performed with either KENO-IV or KENO-Va and HANSEN-ROACH crosssections. The results of these calculations are shown in Table 5. 
Table 4. Considered ${ }^{239} \mathrm{Pu}$ material characteristics

\begin{tabular}{|c|c|c|}
\hline Material form & $\begin{array}{c}\text { Hydrosen to fissile } \\
\text { isotope }\end{array}$ & $\begin{array}{c}\text { Maximum fissile } \\
\text { isotope density }\end{array}$ \\
\hline Metal & 0 & 19.79 \\
\hline Dioxide & 1 & 7.40 \\
\hline Dioxide & 3 & 4.70 \\
\hline Dioxide & 10 & 2.10 \\
\hline Dioxide & 20 & 1.17 \\
\hline
\end{tabular}

\subsection{SUBCRITICAL LOAD LIMITS FOR SINGLE CONTAINERS}

The safety of a single storage well may be examined by comparison with safe values provided in Ref. 8 and consistent with Ref. 9 for identical to Table 5 theoretical density materials as fully water reflected infinite cylinders. Safe values for the considered materials have been extracted from Ref. 8 and are provided in Table 6 . These values offer assurance for the safety of individual well loading and unloading operations of single units.

\section{INVESTIGATION OF HOPPER CALCULATIONS}

The calculations reported in Sect. 4 were performed in 1985 as part of a criticality safety question brought by Chemical Technology Division. The benchmark calculations in Appendix A were intended to support the calculations of Sect. 4 but due to changes in computer hardware, software, and updates to nuclear data libraries from 1985 to the present, it was felt that confirmation of some of the Sect. 4 calculations was needed. Consequently, a new model o: the Intercell Storage Wells 2 and 3 was prepared.

\subsection{COMPUTATIONAL MOUEL}

The programs and cross-section libraries are the same as those mentioned in Sect. 3.1. The waste material was assumed to be either plutonium metal (PLUTONIUMALP in the SCALE library) or plutonium oxide $\left(\mathrm{PuO}_{2}\right)$, as appropriate. Water was added to the waste material to provide the desired $\mathrm{H} / \mathrm{Pu}$ ratios. The SCALE entry CARBON-STEEL was used for the cross-section data for the steel liners of the storage wells. The lead liners were modeled as shown in Fig. 2; SCALE entry was full-density PB. The lead shot was assumed to have a packing fraction of 0.7402 , corresponding to a hexagonal close-packed lattice. Again, the SCALE library entry PB was used. The SCALE library entry ORCONCRETE was used for the cross section data for the intercell walls. The calculations were perfermed on the IBM 3090 using the NCSS procedure.

For the vaste material expected to be loaded into the storage wells (see Sect. 2.3) a maximum H/Pu ratio of 0.3 is expected. As noted in Sect. 2, the radius of the individual storage wells is $5.08 \mathrm{~cm}$. Based on the well radius and Hopper's data in Table 5, eight cases were selected for recalculation. Note that the $\mathrm{H} / \mathrm{Pu}$ ratios of zero and 1 bracket the current waste material. A comparison of the current calculated values to those from Sect. 4 is shown in Table 7. Even though many nuclides in the Hansen-Roach library were updated in 1989, agreement is excellent. 
Table 5. Intercell 2 and $3{ }^{239} \mathrm{Pu}$ results

\begin{tabular}{|c|c|c|c|c|c|}
\hline $\begin{array}{l}\text { Material } \\
\text { form }\end{array}$ & $\begin{array}{c}\mathrm{H} / \mathrm{Pu} \\
\text { atom/ratio }\end{array}$ & $\begin{array}{c}{ }^{239} \mathrm{Pu} \text { density } \\
(\mathrm{g} / \mathrm{cc})\end{array}$ & $\begin{array}{l}\text { Radius } \\
(\mathrm{cm})\end{array}$ & $k$-eff & $\boldsymbol{\sigma}$ \\
\hline \multirow[t]{16}{*}{ Metal } & 0 & 19.700 & 3.1 & 1.287 & 0.006 \\
\hline & & 5.910 & 3.1 & 0.659 & 0.004 \\
\hline & & 12.214 & 3.1 & 0.985 & 0.005 \\
\hline & & 11.623 & 3.1 & 0.958 & 0.006 \\
\hline & & 11.426 & 4.2 & 1.229 & 0.606 \\
\hline & & 3.349 & 4.2 & 0.667 & 0.004 \\
\hline & & 7.486 & 4.2 & 0.991 & 0.006 \\
\hline & & 6.698 & 4.2 & 0.950 & 0.005 \\
\hline & & 8.274 & 4.8 & 1.173 & 0.005 \\
\hline & & 2.561 & 4.8 & 0.640 & 0.005 \\
\hline & & 5.910 & 4.8 & 0.975 & 0.006 \\
\hline & & 5.516 & 4.8 & 0.954 & 0.005 \\
\hline & & 7.289 & 5.08 & 1.160 & 0.006 \\
\hline & & 2.187 & 5.08 & 0.630 & 0.004 \\
\hline & & 5.267 & 5.08 & 0.974 & 0.005 \\
\hline & & 5.012 & 5.08 & 0.953 & 0.005 \\
\hline \multirow[t]{12}{*}{ Dioxides } & 1 & $12.950^{\mathrm{a}}$ & 4.2 & 1.435 & 0.006 \\
\hline & & 3.922 & 4.2 & 0.749 & 0.005 \\
\hline & & 6.512 & 4.2 & 1.001 & 0.004 \\
\hline & & 5.994 & 4.2 & 0.958 & 0.005 \\
\hline & & $9.250^{\mathrm{a}}$ & 4.8 & 1.315 & 0.005 \\
\hline & & 2.812 & 4.8 & 0.716 & 0.004 \\
\hline & & 5.328 & 4.8 & 1.001 & 0.005 \\
\hline & & 4.884 & 4.8 & 0.961 & 0.005 \\
\hline & & $7.992^{\mathrm{a}}$ & 5.08 & 1.296 & 0.005 \\
\hline & & 2.397 & 5.08 & 0.705 & 0.005 \\
\hline & & 4.712 & 5.08 & 0.986 & 0.005 \\
\hline & & 4.418 & 5.08 & 0.963 & 0.005 \\
\hline
\end{tabular}

${ }^{2}$ Value exceeds theoreical density. 
Table 5. (continued)

\begin{tabular}{|c|c|c|c|c|c|}
\hline $\begin{array}{c}\text { Material } \\
\text { form }\end{array}$ & $\begin{array}{c}\mathrm{H} / \mathrm{Pu} \\
\text { atom/ratio }\end{array}$ & $\begin{array}{c}{ }^{239} \mathrm{Pu} \text { density } \\
(\mathrm{g} / \mathrm{cc})\end{array}$ & $\begin{array}{l}\text { Radius } \\
\text { (cm) }\end{array}$ & k-eff & $\boldsymbol{\sigma}$ \\
\hline \multirow[t]{12}{*}{ Dioxides } & 3 & $8.3 i 9^{2}$ & 4.2 & 1.301 & 0.005 \\
\hline & & $2.49_{i}$ & 4.2 & 0.657 & 0.004 \\
\hline & & $5.170^{4}$ & 4.2 & 0.993 & 0.005 \\
\hline & & $4.794^{\circ}$ & 4.2 & 0.967 & 0.005 \\
\hline & & $5.828^{2}$ & 4.8 & 1.200 & 0.005 \\
\hline & & 1.739 & 4.8 & 0.629 & 0.005 \\
\hline & & 4.042 & 4.8 & 1.000 & 0.005 \\
\hline & & 3.572 & 4.8 & 0.932 & 0.005 \\
\hline & & $4.940^{\mathrm{a}}$ & 5.08 & 1.154 & 0.005 \\
\hline & & 1.482 & 5.08 & 0.616 & 0.004 \\
\hline & & 3.630 & 5.08 & 0.986 & 0.004 \\
\hline & & 3.348 & 5.08 & 0.943 & 0.004 \\
\hline \multirow[t]{12}{*}{ Dioxides } & 10 & $3.423^{2}$ & 4.2 & 1.102 & 0.006 \\
\hline & & 1.029 & 4.2 & 0.540 & 0.004 \\
\hline & & $2.772^{\mathrm{a}}$ & 4.2 & 0.980 & 0.005 \\
\hline & & $2.604^{a}$ & 4.2 & 0.947 & 0.005 \\
\hline & & $2.415^{\mathrm{a}}$ & 4.8 & 1.023 & 0.005 \\
\hline & & 0.735 & 4.8 & 0.512 & 0.004 \\
\hline & & $2.184^{u}$ & 4.8 & 0.959 & 0.005 \\
\hline & & $2.142^{\mathrm{a}}$ & 4.8 & 0.954 & 0.005 \\
\hline & & 2.080 & 5.08 & 0.994 & 0.005 \\
\hline & & 0.624 & 5.08 & 0.504 & 0.004 \\
\hline & & 1.949 & 5.08 & 0.960 & 0.005 \\
\hline & & 1.909 & 5.08 & 0.950 & 0.005 \\
\hline
\end{tabular}

'Value exceeds theoretical density. 
Table 5. (continued)

\begin{tabular}{|c|c|c|c|c|c|}
\hline $\begin{array}{l}\text { Material } \\
\text { form }\end{array}$ & $\begin{array}{c}\mathbf{H} / \mathbf{P u} \\
\text { atom/ratio }\end{array}$ & $\begin{array}{l}{ }^{239} \text { Pu density } \\
\text { (g/cc) }\end{array}$ & $\begin{array}{c}\text { Radius } \\
\text { (cm) }\end{array}$ & $k$-eff & $\sigma$ \\
\hline \multirow[t]{15}{*}{ Dioxides } & 20 & $2.363 *$ & 3.1 & 0.909 & 0.004 \\
\hline & & $4.025 *$ & 3.1 & 1.233 & 0.005 \\
\hline & & $2.574^{*}$ & 3.1 & 0.956 & 0.006 \\
\hline & & $2.551 *$ & 3.1 & 0.944 & 0.005 \\
\hline & & $1.322^{*}$ & 4.2 & 0.831 & 0.005 \\
\hline & & $2.258 *$ & 4.2 & 1.139 & 0.005 \\
\hline & & $1.685^{*}$ & 4.2 & 0.967 & 0.005 \\
\hline & & $1.638 *$ & 4.2 & 0.947 & 0.005 \\
\hline & & 0.948 & 4.8 & 0.791 & 0.005 \\
\hline & & $1.615^{*}$ & 4.8 & 1.059 & 0.005 \\
\hline & & $1.346^{*}$ & 4.8 & 0.972 & 0.005 \\
\hline & & $1.275^{*}$ & 4.8 & 0.934 & 0.005 \\
\hline & & 0.808 & 5.08 & 0.759 & 0.005 \\
\hline & & $1.373^{*}$ & 5.08 & 1.040 & 0.005 \\
\hline & & $1.190 *$ & 5.08 & 0.949 & 0.005 \\
\hline
\end{tabular}

*Value exceeds theoretical density.

Table 6. Maximum subcritical fully water reflected single infinite cylinders of ${ }^{239} \mathrm{Pu}$ metal

\begin{tabular}{|c|c|c|c|}
\hline H to Pu & $\begin{array}{c}\text { Pu density } \\
(\mathbf{g} / \mathbf{c c})\end{array}$ & $\begin{array}{c}\text { Diameter } \\
(\mathbf{c m})\end{array}$ & $\begin{array}{c}\text { Pu loading } \\
(\mathbf{k g} / \mathbf{f t})\end{array}$ \\
\hline 0 & 19.70 & 4.19 & 8.32 \\
\hline 1 & 7.4 & 7.29 & 9.44 \\
\hline 3 & 4.7 & 8.89 & 8.91 \\
\hline 10 & 2.1 & 11.00 & 6.08 \\
\hline 20 & 1.27 & 11.81 & 3.90 \\
\hline
\end{tabular}


Table 7. Comparison of Intercell 2 and 3 calculations for ${ }^{239} \mathrm{Pu}$

\begin{tabular}{|c|c|c|c|c|c|c|}
\hline \multirow{3}{*}{$\begin{array}{c}\text { Material } \\
\text { form }\end{array}$} & \multirow{3}{*}{$\begin{array}{r}\mathrm{H} \text { to } \mathrm{Pu} \\
\text { atom ratio }\end{array}$} & \multirow{3}{*}{$\begin{array}{c}{ }^{239} \mathrm{Pu} \text { density } \\
(\mathrm{g} / \mathrm{cc})\end{array}$} & \multicolumn{4}{|c|}{ Calculated k-eff } \\
\hline & & & \multicolumn{2}{|c|}{ Hopper (85) } & \multicolumn{2}{|c|}{ Current } \\
\hline & & & $k$-eff & Std. dev. & $k$-eff & Std. dev. \\
\hline Metal & 0 & 2.187 & 0.630 & 0.004 & 0.645 & 0.003 \\
\hline Metal & 0 & 5.012 & 0.953 & 0.005 & 0.961 & 0.003 \\
\hline Oxide & 1 & 4.418 & 0.963 & 0.005 & 0.966 & 0.003 \\
\hline Oxide & 3 & 1.482 & 0.616 & 0.004 & 0.615 & 0.002 \\
\hline Oxide & 3 & 3.348 & 0.943 & 0.004 & 0.958 & 0.003 \\
\hline Oxide & 10 & 0.624 & 0.504 & 0.004 & 0.505 & 0.002 \\
\hline Oxide & 10 & 1.909 & 0.950 & 0.005 & 0.959 & 0.003 \\
\hline Oxide & 20 & 0.808 & 0.759 & 0.005 & 0.767 & 0.003 \\
\hline
\end{tabular}

\subsection{VERIFICATION OF ASSUMPTIONS FOR SECTION \& CALCULATIONS}

Table 7 provides certification that the Sect. 4 calculations were reproducible. Investigations were conducted to determine if what was intended to be calculated (safety limits) was calculated.

Curious as to the existence of interaction between the wells, a calculation was performed in which all but one of the storage wells was replaced with concrete to estimate the amount of interaction between the wells. The waste material was the same as that listed in the first entry of Table 7 . The calculated $\mathrm{k}$-effective was $0.536 \pm 0.003$. Thus, there is some interaction between loaded storage wells and it is necessary to model all wells (requiring KENO-Va and CSAS25) rather than model a single well. Had this not been the case, a less expensive and equally as accurate calculation (for an isolated, single well) could have been performed using a one-dimensional, discrete-ordinates model (XSDRNPM, CSAS1x).

Upon examination of the input for the cases listed in Table 7, one minor difference was found. The packing fraction for the lead shot in the older, Hopper models was assumed to be 0.5 . The value for the current model was 0.7405 . Even though the worth of this zone was believed to be small, the first case in Table 7 was recalculated with a lead shot packing fraction of 0.5 . The calculated value of $k$-effective was $0.643 \pm 0.003$. Thus the difference between $k$-effectives for the two packing fractions is statistically insignificant.

It was noted earlier that the concrete walls in the KENO-Va model were assumed to be $10 \mathrm{ft}$ thick to account for room return of neutrons. Since the actual walls are $5 \mathrm{ft}$ thick, a calculation was performed with that concrete thickness to determine the impact of the additional $5 \mathrm{ft}$ of concrete on k-effective. The same CSAS25 model was used for these calculations as was used for the calculations reported in Table 7; however, the fuel was assumed to be a mixture of $\mathrm{PuO}_{2}$ at $20 \%$ of theoretical density and $\mathrm{UO}_{2}$ at $80 \%$ of theoretical density. The water content of the fuel was zero. The value of $\mathrm{k}$-effective for a 5 -ft-thick wall was $0.673 \pm 0.002$. The value for a 10 -ft-thick wall was $0.672 \pm 0.002$. One can conclude that the number of neutrons leaking from the 5-ft system is small and one can ignore the possibility of interactions with other materials that might be stored in either cell 2 or 3 . 
Even though the actual uranium-to-plutonium ratio of the waste to be received in Building 3019 is not known, the data supplied in Table 1 imply that the ratio of $\mathrm{Pu} /(\mathrm{Pu}+\mathrm{U})$ will be less than or equal to 0.20. Since all of Hopper's calculations had been for pure plutonium systems, an investigation of the effect of uranium on calculated k-effective was conducted. The 5-ft-thick wall case described in the previous paragraph was rerun with the uranium (natural uranium isotopics) removed. The calculated value of $k$-effective decreased to $0.618 \pm 0.002$.

The $8 \%$ decrease in k-effective due to the removal of natural uranium implied that material was contributing in a significant manner to the reactivity of the system. Investigation of the number of fissions per energy group revealed that $27 \%$ of the fissions were occurring at neutron energies above 1.4 $\mathrm{MeV}$, an energy range where the ${ }^{238} \mathrm{U}$ fission cross section is about 1 barn. Investigation of the ${ }^{235} \mathrm{U}$, ${ }^{238} \mathrm{U}$, and ${ }^{239} \mathrm{Pu}$ atom densities and fast cross sections revealed that in this energy range, ${ }^{239} \mathrm{Pu}$ accounted for about $55 \%$ of the total fissions, and ${ }^{238} \mathrm{U}$ accounted for $45 \%$.

The finding that ${ }^{238} \mathrm{U}$ has a significant reactivity impact for dry systems-when the H/Pu ratio rises to 20 , the percentage of fissions occurring above $1.4 \mathrm{MeV}$ drops to $5 \%$-instigated an extension of Hopper's work. The input for second entry in Table $7\left({ }^{39} \mathrm{Pu}\right.$ density $\left.=5.012\right)$ was modified via the addition of natural uranium dioxide. With a plutonium metal density of $19.84 \mathrm{~g} / \mathrm{cc}$, the maximum theoretical uranium dioxide density is $0.74 \% 4 \times 10.95=8.184 \mathrm{~g} / \mathrm{cc}$. This quantity of uranium was added to the input for the second entry, and k-effective was calculated to be $1.005 \pm 0.003$. In this case, the addition of natural uranium has driven a subcritical system critical. Establishing the limiting plutonium concentration based on calculations that only include plutonium oxide would be nonconservative.

The third entry in Table $7\left({ }^{239} \mathrm{Pu}\right.$ density $\left.=4.418\right)$ was also recalculated with added uranium. The voided region (39.6\% of the waste volume) was replaced with natural uranium dioxide. The calculated $k$-effective was $0.991 \pm 0.003$. This is a statistically significant increase over the case with no uranium present, albeit less of an increase than for the case where $\mathrm{H} / \mathrm{Pu}=0$.

A third examination of the effect of added uranium was conducted using the dataset corresponding to the fifth entry in Table 7 (plutonium density of $3.348 \mathrm{~g} / \mathrm{cc}$ ). A review of the atom densities showed that there was $25 \%$ void in this waste material. Uranium dioxide at $25 \%$ of theoretical density was added to the CSAS2 model, and $k$-effective was calculated to be $0.943 \pm 0.002$. Statistically, this value is not greater than the case in Table 7 (no uranium present). Consequently, an H/Pu ratio of at least 3 removes the positive worth.

The purpose of the uranium study relates to the assumptions regarding the material that fills the void when the plutonium loading is less than theoretical density. If the void is assumed to be filled with water, then the $\mathrm{H} / \mathrm{Pu}$ ratio will be sufficiently high such that the increase in reactivity due to the assumed increase in moderation will outweigh the fast fission effect due to any ${ }^{238} \mathrm{U}$ which may be present. However, if the analyst accepts the certified water content as input to the k-effective calculation, then the uranium content of the waste MUST be included in the computational model because it may have a positive reactivity effect. If the uranium is not accurately known, then all of the remaining "void" region in the waste should be assumed to be uranium.

An alternative, simpler, but much more conservative procedure is to treat all fissionable materials as if they were ${ }^{239} \mathrm{Pu}$ when the water content is below $\mathrm{H} / \mathrm{Pu}=3$. Since the expected well loadings from the waste described in Tables 1 and 2 are quite small, about $0.5 \mathrm{~kg}$ per linear foot, this practice could be adopted were it not for the results of concrete induced reactivity studies described subsequently. 
For the specific waste being addressed in this report, the presence of uranium in the waste is not a problem. Because the $\mathrm{Pu} /(\mathrm{Pu}+\mathrm{U})$ ratio will always be less than or equal to 0.20 , the maximum possible plutonium content is $2.209 \mathrm{~g} / \mathrm{cc}$. Given that the water content of the waste is less than $0.2 \mathrm{wt}$ $\%$, examination of relevant cases from Table $5(\mathrm{H} / \mathrm{Pu}$ ratios of 0 and 1$)$ reveal that this configuration is far subcritical (k-effectives of about 0.70 ). The added reactivity due to the presence of uranium in a dry system will be far less than the amount needed to violate a safety limit.

As noted previously, the 1985 Hopper calculational models had assumed the cell wall concrete to be the composition specified as ORCONCRETE in the SCALE System. At the start of this study it was speculated that the 3019 cell walls were probably composed of Barytes concrete. An investigation into the reactivity effect of substituting Barytes for ORCONCRETE and varying the water content in the concrete was conducted. Atom densities were calculated using Ref. 10 and are reported in Table 8.

Table 8. Atom densities in Barytes concrete

\begin{tabular}{|c|c|c|}
\hline \multirow{2}{*}{ Element } & \multicolumn{2}{|c|}{ Atom Density (atoms/bn $\cdot \mathrm{cm}^{\mathrm{a}}$} \\
\cline { 2 - 3 } & With Rebar & No Rebar \\
\hline $\mathrm{H}$ & $1.40844 \mathrm{E}-2^{\mathrm{b}}$ & $1.45200 \mathrm{E}-2^{\mathrm{c}}$ \\
\hline $\mathrm{O}$ & $4.16247 \mathrm{E}-2^{\mathrm{b}}$ & $4.29121 \mathrm{E}-2^{\mathrm{c}}$ \\
\hline $\mathrm{Mg}$ & $9.51809 \mathrm{E}-5$ & $9.81246 \mathrm{E}-5$ \\
\hline $\mathrm{Al}$ & $3.00953 \mathrm{E}-4$ & $3.10261 \mathrm{E}-4$ \\
\hline $\mathrm{Si}$ & $7.32168 \mathrm{E}-4$ & $7.54812 \mathrm{E}-4$ \\
\hline $\mathrm{S}$ & $6.57595 \mathrm{E}-3$ & $6.77933 \mathrm{E}-3$ \\
\hline $\mathrm{Ca}$ & $2.45317 \mathrm{E}-3$ & $2.52904 \mathrm{E}-3$ \\
\hline $\mathrm{Fe}$ & $4.16972 \mathrm{E}-3$ & $1.71648 \mathrm{E}-3$ \\
\hline $\mathrm{Ba}$ & $6.59790 \mathrm{E}-3$ & $6.80196 \mathrm{E}-3$ \\
\hline
\end{tabular}

'E-2 should be read as $\times 10^{2}$.

bValues shown are for $100 \%$ water retention. Using ANSI/ANS Standard 6.4-1977, the mil.imum bound water content would be $0.064 \mathrm{~g} / \mathrm{cm}^{3}$, yielding $\mathrm{H}$ atom density of $4.15055 \mathrm{E}-3$ and $\mathrm{O}$ atom density of $3.66152 \mathrm{E}-2$ (some $\mathrm{O}$ is from concrete mix).

'Values shown are for $100 \%$ water retention. Using ANSI/ANS Standard 6.4-1977, the minimum bound water content would be $0.064 \mathrm{~g} / \mathrm{cm}^{3}$, yielding $\mathrm{H}$ atom density of $4.27892 \mathrm{E}-3$ and $\mathrm{O}$ atom density of $3.77476 \mathrm{E}-2$ (some $\mathrm{O}$ is from concrete mix).

The second and seventh entries from Table 7 were recalculated using atom densities from Table 8 . Those results, along with calculated k-eftectives for other types of concrete, are shown in Table 9. The final entries in the table are for the actual concrete composition as determined in June 1992 and reported in Appendix C.

It is apparent that the drier the concrete, the more reactive the system. If the intercell 2 and 3 concrete could have been certified as Barytes with 3\% rebar, then Hopper's previous calculations would have been referable by comparison to the verified, validated calculations presented in this memorandum.

With the provision of the rneasured concrete data given in Appendix C, the 1985 calculations are shown to be nonconservative. Consequently, the derived fits to these data - presented in Appendix $\mathrm{E}$ for instructive purposes only, not for use - cannot provide assurance of subcriticality for the storage of the NFS waste material. 
Table 9. Impact of concrete composition on calculated k-effective

\begin{tabular}{|c|c|c|}
\hline \multirow[b]{2}{*}{ Concrete types } & \multicolumn{2}{|c|}{ k-effectives } \\
\hline & Table 7, Case $2^{a}$ & Table 7, Case $7^{b}$ \\
\hline Oak Ridge $^{c}$ & $0.961 \pm 0.003$ & $0.959 \pm 0.003$ \\
\hline Magnuson (very dry) d,e & $1.05052 \pm 0.00311$ & $1.02408 \pm 0.00287$ \\
\hline Barytes, No Rebar; All $\mathrm{H}_{2} \mathrm{O}^{\circ}$ & $0.86293 \pm 0.00291$ & $0.87591 \pm 0.00283$ \\
\hline Barytes, No Rebar; Bound $\mathrm{H}_{2} \mathrm{O}^{\circ}$ & $0.98607 \pm 0.00291$ & $0.97262 \pm 0.00304$ \\
\hline Barytes, Rebar; All $\mathrm{H}_{2} \mathrm{O}^{\circ}$ & $0.84555 \pm 0.00300$ & $0.86241 \pm 0.00286$ \\
\hline Barytes, Rebar; Bound $\mathrm{H}_{2} \mathrm{O}^{\circ}$ & $0.96068 \pm 0.00321$ & $0.96275 \pm 0.00281$ \\
\hline Appendix C Concrete $(0.5$ wt $\% \mathrm{H})$ & $1.04725 \pm 0.00312$ & $1.01862 \pm 0.00292$ \\
\hline
\end{tabular}

${ }^{2}$ Metal, $\mathrm{H} / \mathrm{Pu}=0, \mathrm{Pu}-239$ den. $=5.012 \mathrm{~g} / \mathrm{cc}$.

bOxide, $\mathrm{H} / \mathrm{Pu}=10$, Pu-239 den. $=1.909 \mathrm{~g} / \mathrm{cc}$.

'Hopper assumption, SCALE id is ORCONCRETE.

${ }^{\mathrm{d} A}$ A SCALE composition, id is MGCONCRETE.

'Calculation performed with unverified version of SCALE4 on the ucray, Spring 1992.

\section{COMPUTATIONS AND SAFETY ANALYSES SPECIFIC TO NFS WASTE}

The discussions in Sects. 4 and 5 provide support for the conclusion that NFS waste can be safely stored in the proposed fashion. However, uncertainty exists in the safety margin due to the recently determined cell wall composition. In an attempt to provide further assurance that the proposed storage configuration is safely subcritical, a set of calculations was performed for the Intercell 2 and3 storage array under "normal" and abnormal NFS storage conditions.

\subsection{METHODOLOGY}

The CSAS25 module of the SCALE system ${ }^{5}$ was used to compute k-effectives for several storage configurations. The analyses were performed with the same code system and cross section library as were used in the validation calculations, which were discussed in Appendix A. All of the datasets for the cases presented in this section are stored on the floppy disk attached to the back cover of this report. They are in the subdirectory named section6.dir.

\subsection{COMPUTATIONAL MODELS}

The dimensions and positions in Figs. 1 and 2 were used to create the Monte Carlo (KENO) model. Unlike the models used to generate the calculations reported in Sect. 4, these models incorporated the actual concrete thickness ( $5 \mathrm{ft}$ ) and composition as given in Appendix C.

The steel bottles that contain the waste were not included in the KENO model, and the waste material was assumed to occupy the entire volume of the storage well. Calculations in Sect. 4 showed that spreading the fissile material over the entire volume was conservative.

The normal configuration was defined to be a fuel loading of $260 / \mathrm{g}{ }^{239} \mathrm{Pu}$ per canister. The water content was set at $0.2 \mathrm{wt} \%$. Full-density graphite was added to the waste region to simulate the reactivity impact of unknown waste constituents. A listing of the normal case input is given in Appendix F. 
Ten abnormal configurations were considered. In all cases, the fuel density was set at $1.2 \mathrm{~kg}{ }^{239} \mathrm{Pu}$ per foot ( 2.5 times the expected value). This is the current maximum fissile loading limit for intercell storage in Building 3019.

For the first abnormal case, the $\mathrm{Pu} /(\mathrm{Pu}+\mathrm{U})$ ratio was 0.2 . The fuel form was oxide. The water content of the fuel was $0.1 \mathrm{wt} \%$-the value specified in Ref. 2 for pellets. The carbon steel liner in each well was modeled, but the waste containers were not modeled. Unlike the normal case, no graphite was mixed with the waste. A second case was executed with the water content increased to 0.2 wt \%-the value specified in Ref. 2 for all forms of mixed oxide other than pellets. To examine the effect of miscellaneous and/or unknown materials mixed with the waste material, full-density graphite was added to the model that contained 0.2 wt \% water. Note that this third configuration is physically impossible to obtain, but is conservative. To protect against uncertainty in the water content of the waste material, two cases were examined in which the water content was increased to $0.4 \mathrm{wt} \%$ (Case 4 , a doubling of expected water content) and $1.0 \mathrm{wt} \%$ (Case 5, a conservative water content as identified in Appendix D).

A sixth abnormal case was considered in which a centrally located storage well was assumed to be flooded. Based on the dimensions of the waste storage canister as contained in Ref. 2, the free volume in the storage well was computed. The waste container was assumed to be water-tight, but all free volume in the storage well was assumed to be flooder? (see Appendix D). The water content of the waste was $0.2 \mathrm{wt} \%$ and full density graphite was mixed with the fuel. In the seventh case, the water content of the cell wall concrete was set to zero. This case was considered due to the fact that the concrete analysis presented in Appendix $\mathrm{C}$ did not provide a lower bound for the water content.

In Case 8, two adjacent storage wells were flooded. This case corresponds to the maximum number of storage welis which might be open at anytime during the waste loading or unloading procedures.

In Cases 9 and 10 (1.0 and 0.2 wt \% water, respectively), all of the storage wells are assumed to be flooded. While it is uncertain if this is a credible abnormal configuration, it is considered in order to relieve concern regarding possible, unidentified water ingress pathways.

\subsection{RESULTS}

Calculated $k$-effective for the normal case was $0.34795 \pm .00171$. The average fission group value was 13.2, within the validated range as shown in Appendix A. K-effectives for the ten abnormal cases are shown in Table 10. Average fission group (avg) values are also shown. Note that all configurations are far subcritical and all average values are within the validated range. Note that, contrary to trends derived from Table 9, when all water is removed from actual cell wall concrete, $k$-effective remains unchanged relative to the nominal concrete condition. Note also that flooding of ALL storage wells yields no significant reactivity increase compared with flooding a single well. 
Table 10. Reactivity parameters for abnormal intercell 2 and 3 storage configurations

\begin{tabular}{|c|c|c|c|c|c|c|}
\hline \multirow[b]{2}{*}{ ID No. } & \multicolumn{4}{|c|}{ Case } & \multirow[b]{2}{*}{ k-effective } & \multirow{2}{*}{$\begin{array}{c}\text { Average } \\
\text { fission grou }\end{array}$} \\
\hline & $\mathrm{gr}^{239} \mathrm{Pu} / \mathrm{ft}$ & $\mathrm{H}_{2} \mathrm{O}$ wt $\%$ & H/Pu ratio & C present & & \\
\hline 1 & 1200 & 0.1 & 0.283 & No & $0.420 \pm 0.002$ & 11.5 \\
\hline 2 & 1200 & 0.2 & 0.566 & No & $0.420 \pm 0.002$ & 11.5 \\
\hline 3 & 1200 & 0.2 & 0.566 & Yes & $0.450 \pm 0.002$ & 11.5 \\
\hline 4 & 1200 & 0.4 & 1.134 & No & $0.426 \pm 0.002$ & 11.5 \\
\hline 5 & 1200 & 1.0 & 2.854 & No & $0.436 \pm 0.002$ & 11.6 \\
\hline 6 & $1200^{2}$ & 0.2 & 0.566 & Yes & $0.451 \pm 0.002$ & 11.6 \\
\hline 7 & $1200^{a, b}$ & 0.2 & 0.566 & Yes & $0.450 \pm 0.002$ & 9.3 \\
\hline 8 & $1200^{c}$ & 0.2 & 0.566 & Yes & $0.447 \pm 0.002$ & 11.5 \\
\hline 9 & $1200^{d}$ & 1.0 & 2.854 & Yes & $0.446 \pm 0.002$ & 11.5 \\
\hline 10 & $1200^{d}$ & 0.2 & 0.566 & Yes & $0.446 \pm 0.002$ & 11.5 \\
\hline
\end{tabular}

'Central storage well flooded.

'Water content in cell wall concrete set to zero.

Two central storage wells flooded.

${ }^{\mathrm{d}}$ All storage wells flooded.

\section{CONDITIONS FOR STORAGE WELL USE AND ASSIGNMENT OF SAFE FISSILE MATERIAL LIMITS}

The following conditions must be met.

\subsection{INITIAL CONDITIONS}

Intercell 2 and 3 storage wells shall be confirmed as empty before loading waste canisters.

\subsection{MATERIAL DEFINITION AND CONTAINMENT}

The safe storage limits noted in Sects. 5 and 6 are predicated upon the specified hydrogen to fissile isotope atom ratios and material containment. Material definition and quality and material containment integrity should be controlled or limited such that unlikely, yet credible, changes in material form and/or containment will not exceed the safe load limits and respective hydrogen to fissile isotope atom ratios as set forth in Ref. 2. It should be noted that the Pu loading and hydrogen moderation parameters based upon the waste acceptance criteria are much lower than those used in the earlier, and more general, qualification of the facility (Section 4).

\subsection{FISSILE MATERIAL TRANSFERS TO, FROM, AND AMONG STORAGE WELLS}

The safe mass values in Sect. 6 are predicated on the assumption that the fissile material primary containment is leaktight to water in the event of accidental water flooding. Interim storage of fissile materials outside the wells during transfer to, from, and among storage wells may be accomplished near the storage wells in an authorizer manner with approved storage/transfer containers. An important administrative control in this procedure is the limit of an approved maximum number of waste canisters exterior to the storage containers or storage wells at any time. 


\section{CONCLUSIONS}

An adequate number of criticality computations were performed to permit the characterization of fissile materials interactions for storage in Building 3019 Intercell 2 and 3 Storage Wells. Verified and validated methods and libraries were used to evaluate subcriticality in Intercell 2 and 3 wells for NFS waste. Extension of the evaluation to other, undefined, fissile waste materials would require recalculation of parametric studies performed during the 1985 time frame. Results from the 1985 parametric studies of Intercell 2 and 3 are included in this report (1) to demonstrate the nonconservative effect of using the SCALE Oak Ridge concrete for inappropriately modeling the cell wall concrete composition, and (2) to review the adequacy of using an empirical model for interpreting the KENO Monte Carlo results. 


\section{REFERENCES}

1. R. T. Primm, III, Validation Studies for KENO-IV with Mixed Plutonium-Uranium Critical Experiments, ORNL/TM-9668, November 1985.

2. Oak Ridge National Laboratory Waste Acceptance Criteria for Transuranic Waste from Nuclear Fuel Services, Inc., WM-WMCO-202/R1, April 7, 1992.

3. Personal Communication from A. M. Krichinsky, Chemical Technology Division, Martin-Marietta Energy Systems, Inc., September 22, 1992.

4. Final Safery Analysis Report for the Radiochemical Processing Plant (RPP)," ORNL/CF-81/37, Draft version, cover letter from R. S. Wiltshire to J. A. Lenhard, August 30, 1984.

5. SCALE - A Modular Code System for Performing Standardized Computer Analyses for Licensing Evaluation, NUREG/CR-0200, Rev. 4 (ORNL/NUREG/CSD-2/R4), Vols. I, II, and III (draft February 1990). Available from Radiation Shielding Information Center, Oak Ridge National Laboratory, as CCC-545.

6. N. F. Landers, L. M. Petrie and J. C. Turner, "Martin Marietta Energy Systems Nuclear Criticality Safety Software Verification Plan SRR-0," December 31, 1991, contained in Martin Marietta Energy Systems Nuclear Criticality Safety Software Configuration Control Plan, K/ESH-3, December 18, 1991.

7. American National Standards Institute, Design Criteria for an Independent Spent Fuel Storage Installation (Water Pool Type), Standard Number ANSI/ANS-57.7-1981, 1981.

8. J. T. Thomas, Ed., Nuclear Safety Guide, TID-7016, Revision 2," NUREG/CR-0095, ORNL/NUREG/CSD-6, June 1978.

9. H. C. Paxton and N. L. Pruvost, Critical Dimensions of Systems Containing ${ }^{235} U,{ }^{239} \mathrm{Pu}$, and ${ }^{233} \mathrm{U}$, 1986 Revision, LA-15860-MS, UC-46, Los Alamos National Laboratory, July 1987.

10. E. P. Blizard and L. S. Abbott, Reactor Handbook, Oak Ridge National Laboratory, 1962. 
APPENDIX A

VALIDATION STUDIES WITH URANIUM AND PLUTONIUM OXIDE EXPERIMENTS 


\section{APPENDIX A}

\section{VALIDATION STUDIES WITH URANIUM AND PLUTONIUM OXIDE EXPERIMENTS}

\section{A.1 INTRODUCTION}

Four publicly available documents contain data for critical experiments that have been performed with mixed uranium and plutonium oxide.$^{1-4}$ All these experiments utilize plastic powder as a moderator, and all critical configurations are rectangular parallelepipes. This section includes a description of the $k$-effective calculations of these mixed-oxide critical experiments. A brief review of computational methods is also provided, along with a short discussion of each experimental series. This section is organized such that the calculated k-effectives are grouped according to the articles in which the data are provided. The datasets for all of the critical experiments are stored on the floppy disk attached to the inside of the back cover of this report.

\section{A.2 COMPUTATIONAL METHODS}

Calculations were performed with cross sections from the 16-group Hansen-Roach library. ${ }^{5}$ The SCALE module, CSAS25 was used to process cross-section data and generate k-effectives for the mixed-oxide critical experiments. Atom densities for input to these codes were provided in the articles that describe the critical configurations. All calculations were performed with the same configuration control software as was used to perform the calculations for Intercell Storage 2 and 3 wells of Building 3019.

\section{A.3 CALCULATION OF K-EFFECTIVE FOR MIXED URANIUM AND PLUTONIUM OXIDE EXPERIMENTS}

\section{A.3.1 Unpoisoned Experiments with Little Moderation}

References 1, 7, and 8 provide descriptions of several critical experiments conducted at the Battelle-Pacific Northwest Laboratories (PNL). These experiments were conducted with fuel mixtures containing depleted uranium $\left(0.2 \mathrm{wt} \%{ }^{235} \mathrm{U}\right)$ homogenized with plutonium oxide. The ${ }^{240} \mathrm{Pu}$ content of the plutonium was $11.5 \mathrm{wt} \%$. Three $\mathrm{Pu}:(\mathrm{Pu}+\mathrm{U})$ ratios were examined $(0.29,0.15$, and 0.08$)$. Atom densities for the three fuel mixtures are reported in Table A.1.

The mixed oxide was blended with polystyrene powder to achieve the lesired $\mathrm{H}:(\mathrm{U}+\mathrm{Pu})$ atom ratios. This fuel mixture was compressed to form two types of fuel compacts: some measured 5.1 by 5.1 by 5.1 $\mathrm{cm}$, and the remainder measured 5.1 by 5.1 by $1.3 \mathrm{~cm}$. Each compact was then clad in the $3 \mathrm{M}$ Company's 471 tape.

An approach to critical was performed by stacking the compacts in a rectang:lar parallelepiped configuration. Some configurations had no reflector; others were fully reflected with methacrylate plastic. Critical sizes are provided in Tables A.2 and A.3. 
Table A.1. Description of experimental fuel and reflector for experiments 1453-01 to 15 (Values are $10^{24}$ atoms per cubic centimeter)

\begin{tabular}{|c|c|c|c|}
\hline Material & $\begin{array}{c}29.3 \text { wi } \% \mathrm{Pu} \text { fuel; } \\
2.8 \mathrm{H:}(\mathrm{Pu}+\mathrm{U}) \\
\text { atomic ratio }\end{array}$ & $\begin{array}{c}15.0 \text { wt \% Pu fuel; } \\
2.86 \mathrm{H}:(\mathrm{Pu}+\mathrm{U}) \\
\text { atomic ratio }\end{array}$ & $\begin{array}{c}8.1 \mathrm{wt} \% \mathrm{Pu} \text { fuel; } \\
7.3 \mathrm{H:}(\mathrm{Pu}+\mathrm{U}) \\
\text { atomic ratio }\end{array}$ \\
\hline $\begin{array}{l}\text { Fuel }^{\mathbf{a}} \\
\qquad \begin{array}{l}{ }^{241} \mathrm{Am} \\
{ }^{238} \mathrm{Pu} \\
{ }^{239} \mathrm{Pu} \\
{ }^{240} \mathrm{Pu} \\
{ }^{241} \mathrm{Pu} \\
{ }^{242} \mathrm{Pu} \\
{ }^{235} \mathrm{U} \\
{ }^{238} \mathrm{U} \\
\mathrm{O} \\
\mathrm{C} \\
\mathrm{H}\end{array}\end{array}$ & $\begin{array}{l}1.019 \times 10^{-5} \\
1.833 \times 10^{-6} \\
2.203 \times 10^{-3} \\
2.931 \times 10^{-4} \\
4.934 \times 10^{-5} \\
5.636 \times 10^{-6} \\
9.401 \times 10^{-6} \\
6.172 \times 10^{-3} \\
1.869 \times 10^{-2} \\
2.666 \times 10^{-2} \\
2.417 \times 10^{-2}\end{array}$ & $\begin{array}{l}2.765 \times 10^{-5} \\
5.737 \times 10^{-7} \\
1.118 \times 10^{-3} \\
1.478 \times 10^{-4} \\
2.221 \times 10^{-5} \\
2.370 \times 10^{-6} \\
1.365 \times 10^{-5} \\
7.549 \times 10^{-3} \\
1.840 \times 10^{-2} \\
2.653 \times 10^{-2} \\
2.534 \times 10^{-2}\end{array}$ & $\begin{array}{l}3.132 \times 10^{-5} \\
3.809 \times 10^{-7} \\
3.490 \times 10^{-4} \\
4.678 \times 10^{-5} \\
7.745 \times 10^{-6} \\
1.116 \times 10^{-6} \\
9.116 \times 10^{-6} \\
4.606 \times 10^{-3} \\
1.178 \times 10^{-2} \\
3.567 \times 10^{-2} \\
3.680 \times 10^{-2}\end{array}$ \\
\hline $\begin{array}{c}\text { Cladding } \\
\mathrm{H} \\
\mathrm{C} \\
\mathrm{Cl} \\
\end{array}$ & $\begin{array}{l}4.489 \times 10^{-2} \\
3.111 \times 10^{-2} \\
7.240 \times 10^{-3} \\
\end{array}$ & $\begin{array}{l}4.489 \times 10^{-2} \\
3.111 \times 10^{-2} \\
7.240 \times 10^{-3}\end{array}$ & $\begin{array}{l}4.489 \times 10^{-2} \\
3.111 \times 10^{-2} \\
4.240 \times 10^{-3}\end{array}$ \\
\hline $\begin{array}{c}\text { Reflector } \\
\text { H } \\
\text { C } \\
\text { O }\end{array}$ & $\begin{array}{l}5.666 \times 10^{-2} \\
3.510 \times 10^{-2} \\
1.428 \times 10^{-2}\end{array}$ & $\begin{array}{l}5.666 \times 10^{2} \\
3.510 \times 10^{-2} \\
1.428 \times 10^{-2}\end{array}$ & $\begin{array}{l}5.666 \times 10^{-2} \\
3.519 \times 10^{-2} \\
1.428 \times 10^{-2}\end{array}$ \\
\hline
\end{tabular}

${ }^{2}$ Concentration at time of experiments.

According to Beirman and Clayton:

\begin{abstract}
To provide a more simplified geometry for use in calculations, the reactivity worth of the $1.3-\mathrm{cm}$-thick fuel compacts with respect to the full-sized fuel compacts was determined for each fuel mixture by replacement measurements. The critical height in terms of the full-sized compacts is presented in (Tables A.2 and A.3) for each of the experimental assemblies.
\end{abstract}

In the KENO-Va model of these experiments, each compact in the array was represented discretely. The fractional height was represented as a single, full layer with a thickness equal to the fraction times the height of the compact $(5.1 \mathrm{~cm})$.

Calculated $k$-effectives for the 11 described experiments are reported in Table A.4. The calculations show good agreement with the experimentally determined value of k-effective (1.0) for the $29 \mathrm{wt} \% \mathrm{Pu}$ experiments. 
Table A.2. Critical assembly configurations for $29.3 \mathrm{wt} \% \mathbf{P u}$, $2.8 \mathrm{H}:(\mathrm{Pu}+\mathrm{U}), \mathrm{PuO}_{2}-\mathrm{UO}_{2}$-polystryene fuel compacts

\begin{tabular}{|c|c|c|c|c||}
\hline \multirow{2}{*}{$\begin{array}{c}\text { Experiment } \\
\text { designation }\end{array}$} & Reflected & \multicolumn{3}{|c|}{ Critical number of compacts } \\
\cline { 2 - 5 } & Length & Width & Height $^{\mathrm{a}}$ \\
\hline \hline $1453-01$ & No & 10 & 10 & 8.888 \\
\hline $1453-02$ & Yes & 7 & 11 & 8.252 \\
\hline $1453-03$ & Yes & 8 & 7 & 7.060 \\
\hline $1453-04$ & Yes & 9 & 9 & 5.615 \\
\hline $1453-05$ & Yes & 10 & 10 & 4.316 \\
\hline $1453-06$ & Yes & 12 & 10 & 3.948 \\
\hline $1453-07$ & Yes & 12 & 12 & 3.668 \\
\hline $1453-08$ & Yes & 12 & 13 & 3.578 \\
\hline $1453-09$ & Yes & 14 & 13 & 3.487 \\
\hline $1453-10$ & & & & \\
\hline
\end{tabular}

"The 1.3-cm-thick fuel is expressed as 5.1 fuel by using its measured reactivity worth in terms of the full-size fuel.

Table A.3. Reflected critical assembly configuration for $15 \mathrm{wt} \% \mathbf{P u}$, $2.86 \mathrm{H}:(\mathrm{Pu}+\mathrm{U}), \mathrm{PuO}_{2}-\mathrm{UO}_{2}$-polystyrene fuel compacts

\begin{tabular}{||c|c|c|c|}
\hline \multirow{2}{*}{$\begin{array}{l}\text { Experiment } \\
\text { designation }\end{array}$} & \multicolumn{3}{|c|}{ Critical number of compacts } \\
\cline { 2 - 4 } & Length & Width & Height $^{\mathbf{a}}$ \\
\hline \hline $1453-11$ & 10 & 10 & 10.749 \\
\hline
\end{tabular}

"The 1.3-cm-thick fuel is expressed as 5.1 fuel by using its measured reactivity worth in terms of the full-size fuel.

\section{A.3.2 Poisoned Experiments with Little Moderation}

References 2 and 9 provide descriptions of series of experiments conducted with mixed-oxide and heterogeneously distributed neutron poison materials. The relative worths of plates of aluminum, copper, and copper containing $1 \mathrm{wt} \% \mathrm{Cd}$ were measured for two different mixed oxides. Both sets of fuel were homogeneous mixtures of $\mathrm{PuO}_{2}-\mathrm{UO}_{2}$-polystyrene in the form of $5-$ by $5-\mathrm{cm}$ compacts having varying thicknesses. ${ }^{2}$ 
One fuel had a $\mathrm{H}:(\mathrm{Pu}+\mathrm{U})$ atomic ratio of 2.8 ; the oxide mixture contained $30.3 \mathrm{wt} \% \mathrm{PuO}_{2}$. The plutonium in this fuel had a ${ }^{240} \mathrm{Pu}$-to-total-plutonium atomic ratio of 0.115 . The second fuel had a $\mathrm{H}:(\mathrm{Pu}+\mathrm{U})$ ratio of 30.6 , and the oxide mixture contain $\mathrm{d} 14.62 \mathrm{wt} \% \mathrm{PuO}_{2}$. The plutonium in this fuel contains 7.97 at. $\%{ }^{240} \mathrm{Pu}$. A complete description of each fuel, including cladding, is shown in Table A.5. Atom densities for the three poison plates are shown in Table A.6.

Table A.4. Calculated k-effectives for unpoisoned, low-moderation experiments

\begin{tabular}{|c|c|c|}
\hline Experiment designation & k-ffective $^{\mathbf{a}}$ & $\begin{array}{c}\text { Average energy group } \\
\text { for fissions }\end{array}$ \\
\hline \hline $1453-01$ & $0.99229 \pm 0.00223$ & 8.97497 \\
\hline $1453-02$ & $0.99076 \pm 0.00224$ & 8.97252 \\
\hline $1453-03$ & $0.99905 \pm 0.00223$ & 10.6919 \\
\hline $1453-04$ & $0.99827 \pm 0.00216$ & 10.6876 \\
\hline $1453-05$ & $1.00715 \pm 0.00227$ & 10.6908 \\
\hline $1453-06$ & $0.99958 \pm 0.00247$ & 10.7358 \\
\hline $1453-07$ & $0.99245 \pm 0.00248$ & 10.7985 \\
\hline $1453-08$ & $0.99343 \pm 0.00243$ & 10.8220 \\
\hline $1453-09$ & $0.99562 \pm 0.00230$ & 10.8093 \\
\hline $1453-10$ & $1.00106 \pm 0.00239$ & 10.8307 \\
\hline $1453-11$ & $0.98991 \pm 0.00241$ & 11.5014 \\
\hline
\end{tabular}

${ }^{2}$ Value shown is for KENO-Va using Hansen-Roach cross sections. Uncertainty reported is 1 standard deviation.

b16-energy group, Hansen-Roach structure, $1 \sigma$ uncertainty is approximately 0.003 .

\section{According to Bierman and Clayton, ${ }^{2}$}

\footnotetext{
The critical assemblies consisted of rectang' lar parallelepipeds of fuel fully reflected with $15 \mathrm{~cm}$ of a methacrylate plastic (Plexiglas). All assemblies had a base of nine fuel compacts on a side. The plates, having thicknesses up to approximately $21 / 2 \mathrm{~cm}$ and the same cross-section dimensions as the assemblies, were positioned horizontally in the assemblies. Except for one series of experiments to measure the worth of a plate as a function of position in the assembly, the position of the plates, relative to the bottom of the assembly, was constant for each fuel. This distance from the bottom was such that the plates were approximately centered in the fuel for all the experiments.

In addition to the measurements with copper or copper-cadmium plates, measurements were similarly made without any plates and with aluminum plates to provide a measure of the void effects relative to the poison effects caused by the plates being present in the assemblies.
}

Some critical configurations were achieved by using two poison plates in the assembly. These configurations were generally symmetric with one layer of oxide compacts between the two poison plates. 
A summary of the experimental data presented in Ref. 2 is provided in Tables A.7 and A.8. The fractional blocks were treated computationally as full layers of thinner fuel compacts having a thickness equal to the fractional layer times the full-sized compact. In the KENO-Va models of these experiments, each compact in the array was represented discretely.

Table A.5. Description of experimental fuel and reflector material (Values are atoms per barncentimeter ${ }^{2}$ )

\begin{tabular}{||c|c|c||}
\hline Material & $\begin{array}{c}\text { 2.8 H:(Pu+U) } \\
\text { Fueled experiments }\end{array}$ & $\begin{array}{c}\text { 30.6 H:(Pu+ U) } \\
\text { Fueled experiments }\end{array}$ \\
\hline \hline $\begin{array}{c}\text { Cladding } \\
\text { H }\end{array}$ & $4.489 \times 10^{-2}$ & $4.489 \times 10^{-2}$ \\
$\mathrm{C}$ & $3.110 \times 10^{-2}$ & $3.110 \times 10^{-2}$ \\
$\mathrm{Cl}$ & $0.724 \times 10^{-2}$ & $0.724 \times 10^{-2}$ \\
\hline Reflector & & \\
$\mathrm{H}$ & $5.712 \times 10^{-2}$ & $5.712 \times 10^{-2}$ \\
$\mathrm{C}$ & $3.570 \times 10^{-2}$ & $3.570 \times 10^{-2}$ \\
$\mathrm{O}$ & $1.428 \times 10^{-2}$ & $1.428 \times 10^{-2}$ \\
\hline Fuel ${ }_{\mathrm{Compacts}}{ }^{241} \mathrm{Am}$ & & $5.801 \times 10^{-7}$ \\
${ }^{239} \mathrm{Pu}$ & $1.472 \times 10^{-5}$ & $1.954 \times 10^{-4}$ \\
${ }^{238} \mathrm{Pu}$ & $2.186 \times 10^{-3}$ & 0.0 \\
${ }^{240} \mathrm{Pu}$ & $2.288 \times 10^{-6}$ & $1.702 \times 10^{-5}$ \\
${ }^{241} \mathrm{Pu}$ & $2.927 \times 10^{-4}$ & $1.034 \times 10^{-6}$ \\
${ }^{242} \mathrm{Pu}$ & $5.420 \times 10^{-5}$ & 0.0 \\
$\mathrm{O}$ & $6.751 \times 10^{-6}$ & $3.023 \times 10^{-3}$ \\
${ }^{238} \mathrm{U}$ & $1.864 \times 10^{-2}$ & $1.252 \times 10^{-3}$ \\
${ }^{235} \mathrm{U}$ & $6.162 \times 10^{-3}$ & $1.904 \times 10^{-5}$ \\
$\mathrm{H}$ & $9.269 \times 10^{-6}$ & $4.489 \times 10^{-2}$ \\
$\mathrm{C}$ & $2.432 \times 10^{-2}$ & $4.412 \times 10^{-2}$ \\
\hline \hline
\end{tabular}

${ }^{\mathrm{a}} 1$ barn $=10^{-24} \mathrm{~cm}$.

Table A.6. Composition of neutron poison plates

\begin{tabular}{||c|c|c|c|}
\hline \multirow{2}{*}{ Element } & \multicolumn{3}{|c|}{ Atom Density (atom/trcm) } \\
\cline { 2 - 4 } & Cu plate & Cu-Cd plate & Al plate \\
\hline $\mathrm{Cu}$ & $8.44384 \times 10^{-2}$ & $8.33333 \times 10^{-2}$ & \\
\hline $\mathrm{O}$ & $1.00651 \times 10^{-4}$ & & \\
\hline $\mathrm{C}$ & $1.78929 \times 10^{-5}$ & & \\
\hline $\mathrm{Cd}$ & & $4.71679 \times 10^{-4}$ & \\
\hline $\mathrm{Sn}$ & & $1.13027 \times 10^{-4}$ & \\
\hline $\mathrm{Al}$ & & & $5.88742 \times 10^{-2}$ \\
\hline $\mathrm{Fe}$ & & & $2.03213 \times 10^{-4}$ \\
\hline $\mathrm{Si}$ & & & $2.30900 \times 10^{-4}$ \\
\hline \hline
\end{tabular}

1 barn $=10^{-24} \mathrm{~cm}$ 
Table A.7. Critical assembly configurations of poisoned, plexiglas-reflf :ted 2.8 H: $(\mathbf{P u}+\mathrm{U})$ mixed-oxide compacts

\begin{tabular}{|c|c|c|c|c|}
\hline \multirow{2}{*}{$\begin{array}{c}\text { Experiment } \\
\text { designation }\end{array}$} & $\begin{array}{c}\text { Layers of fuel } \\
\text { below plate } \\
\mathbf{5 . 0 9} \mathbf{~ c m}\end{array}$ & $\begin{array}{c}\text { Type of } \\
\text { poison plate }\end{array}$ & $\mathbf{5 . 0 9} \mathbf{~ c m}$ & $\mathbf{1 . 3 3 9} \mathbf{~ c m}$ \\
\hline $1547-1$ & 3 & $1 / 8$ in $\mathrm{Cu}$ & 2 & 0.502 \\
\hline $1547-2$ & 3 & $3 / 8$ in. $\mathrm{Cu}$ & 2 & 1.321 \\
\hline $1547-3$ & 3 & $3 / 4$ in. $\mathrm{Cu}$ & 2 & 2.536 \\
\hline $1547-4$ & 3 & $1 / 8$ in. $\mathrm{Cu}-\mathrm{Cd}$ & 2 & 0.738 \\
\hline $1547-5$ & 3 & $3 / 8$ in. Cu-Cd & 2 & 1.827 \\
\hline $1547-6$ & 3 & $3 / 4$ in. Cu-Cd & 2 & 3.468 \\
\hline $1547-7$ & 3 & $1 / 8$ in. $\mathrm{Al}$ & 2 & 0.342 \\
\hline $1547-8$ & 3 & $3 / 8$ in. Al & 2 & 0.873 \\
\hline $1547-9$ & 3 & $3 / 4$ in. Al & 2 & 1.688 \\
\hline
\end{tabular}

Calculated $\mathrm{k}$-effectives for the nine experiments conducted with the $2.8 \mathrm{H}:(\mathrm{Pu}+\mathrm{U})$ oxide are shown in Table A.9. No trends in k-effective as a function of either type of poison or poison-plate thickness were observed. Thus, it appears that the fixed poisons examined in these experiments can be modeled accurately with this particular code and library combination.

Calculated $\mathrm{k}$-effectives for the 22 experiments conducted with $30.6 \mathrm{H}:(\mathrm{Pu}+\mathrm{U})$ oxide are shown in Table A.10. The results are somewhat higher than those reported in Table A.9.

Comparison of calculated k-effectives in Table A.10 with the physical data provided in Table A.8 reveals only one trend in $\mathrm{k}$-effectives. The presence of $\mathrm{Cu}$ plates seems to slightly lower calculated k-effective. Considering experiments 1547-10 through 1547-15 and 1547-25 through 1547-28, the value of k-effective decreases from 1.015 to 1.0 as the plate thickness increases. Generally, it appears that the fixed poisons examined in the $30.6 \mathrm{H}:(\mathrm{Pu}+\mathrm{U})$ ratio experiments can be modeled accurately with the code and library combination.

\section{A.3.3 Unpoisoned, High-Moderation Mixed-Oxide Critical Experiments}

Reference 3 contains data for low-moderation oxide critical experiments with high ${ }^{240} \mathrm{Pu}$ content $(23$ wt \%). However, these experiments were not calculated due to their low $\mathrm{Pu}:(\mathrm{Pu}+\mathrm{U})$ ratio (0.08).

References 4, 7, 10, and 11 provide information on three series of critical experiments. These experiments were conducted with mixed-oxide fuel having 30.0 and $14.62 \mathrm{wt} \% \mathrm{Pu}$ and $\mathrm{H}:(\mathrm{Pu}+\mathrm{U})$ ratios of 47.4 and 30.6 respectively. In all three fuels, the plutonium contained $8 \mathrm{wt} \%{ }^{240} \mathrm{Pu}$, and the uranium was depleted to $0.151 \mathrm{wt} \%{ }^{235} \mathrm{U}$. 


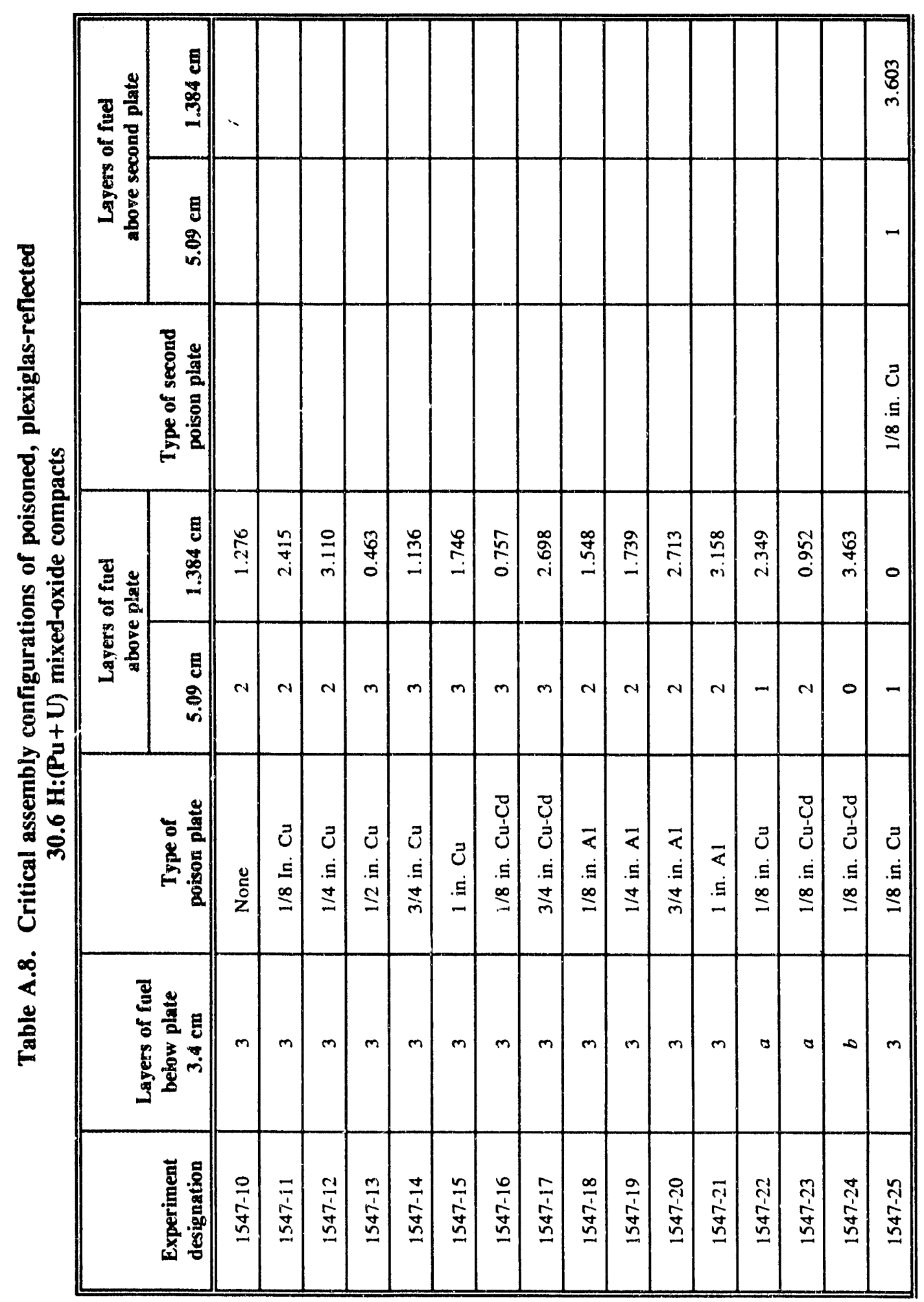




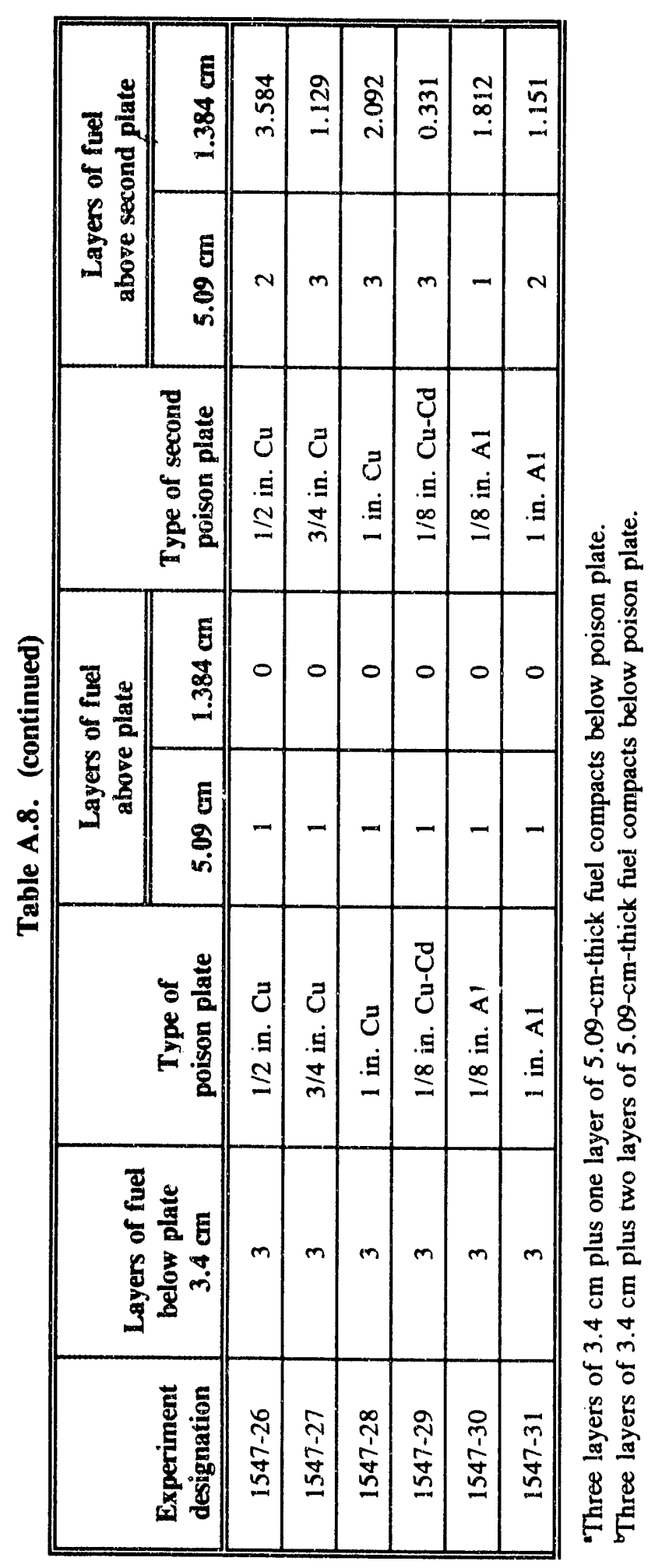


Table A.9. Calculated k-effectives for poisoned, low.moderation experiments with $\mathrm{H}:(\mathrm{Pu}+\mathrm{U})$ ratio $=2.8$

\begin{tabular}{|c|c|c|}
\hline Experiment designation & k-effective & $\begin{array}{l}\text { Average energy group } \\
\text { for fissions }\end{array}$ \\
\hline $1547-1$ & $0.99644 \pm 0.00239$ & 10.739 \\
\hline $1547-2$ & $0.99679 \pm 0.00236$ & 10.682 \\
\hline $1547-3$ & $0.99823 \pm 0.00226$ & 10.695 \\
\hline $1547-4$ & $1.00222 \pm 0.00244$ & 10.6997 \\
\hline $1547-5$ & $0.99371 \pm 0.00237$ & 10.6767 \\
\hline $1547-6$ & $0.99367 \pm 0.00234$ & 10.6108 \\
\hline $1547-7$ & $1.00391 \pm 0.00248$ & 10.7062 \\
\hline $1547-8$ & $1.00414 \pm 0.00228$ & 10.7083 \\
\hline $1547-9$ & $1.00300 \pm 0.00247$ & 10.7166 \\
\hline
\end{tabular}

"Value shown is for KENO-Va using Hansen-Roach cross-sections. Uncertainty reported is one standard deviation.

${ }^{b} 16$-energy-group, Hansen-Roach structure, $1 \sigma$ uncertainty is approximately 0.003 .

Bierman, Clayton, and Hansen ${ }^{4}$ report:

\begin{abstract}
Each of the fuels consisted of a homogeneous mixture of $\mathrm{PuO}_{2}-\mathrm{UO}_{2}$-polystyrene in the form of 2- X 2-in. compacts having thicknesses of 2-, $11 / 2$ - and $1 / 2$-in. Each compact was clad with 6-mil-thick tape (MM\&M \#471). Nuclide composition and densities are given in (Table A.11) for each of the three fuels and for the Plexiglas reflector used in the experiments.
\end{abstract}

The critical assemblies were formed by stacking the oxide compacts into rectangular parallelepiped configurations. The Plexiglas reflector had a thickness of $15 \mathrm{~cm}$. The measured critical assembly parameters are given in Tables A.12 and A.13. The critical sizes given in these two tables are for solid assemblies of fuel only. Experimentally determined corrections have been applied in each case to account for the effects of the cladding material and the presence of voids in the assembly of stacked blocks. Reference 10 provides the actual experimental data in terms of the number of polycubes in the length, width, and height of the assemblies. However, the computer calculations to be described in this section were based on the simpler, solid assembly data.

The calculated k-effectives are shown in Tahle A.14. To provide for easier comparison, the experiments were grouped according to fuel type and reflector, and the means of the calculated k-effectives were tabulated. These mean values are shown in Table A.15. It appears that the bare, $30 \mathrm{wt} \% \mathrm{Pu}$ experiments calculate somewhat lower than the Plexiglas-reflected $30 \mathrm{wt} \% \mathrm{Pu}$ experiments. This trend is not as pronounced in the $14.6 \mathrm{wt} \% \mathrm{Pu}$ experiments. 
Table A.10. Calculated k-effectives for poisoned, low-moderation experiments with $\mathrm{H}:(\mathrm{Pu}+\mathrm{U})$ ratio $=\mathbf{3 0 . 6}$

\begin{tabular}{|c|c|c|}
\hline Experinuent designation & k-effective ${ }^{a}$ & $\begin{array}{l}\text { Average energy group } \\
\text { for fissions }\end{array}$ \\
\hline $1547-10$ & $1.01640 \pm 0.00273$ & 15.0134 \\
\hline $1547-11$ & $1.01597 \pm 0.00251$ & 14.9997 \\
\hline $1547 \cdot 12$ & $1.00939 \pm 0.00256$ & 14.9959 \\
\hline $1547-13$ & $1.00513 \pm 0.00274$ & 14.9859 \\
\hline $1547-14$ & $1.00532 \pm 0.00271$ & 14.9899 \\
\hline $1547-15$ & $1.00365 \pm 0.00290$ & 14.9788 \\
\hline $1547-16$ & $1.01563 \pm 0.00235$ & 14.982 \\
\hline $1547-17$ & $1.00850 \pm 0.00261$ & 14.9715 \\
\hline $1547-18$ & $1.01557 \pm 0.0027 i$ & 15.0203 \\
\hline $1547-19$ & $1.01759 \pm 0.00264$ & 15.0106 \\
\hline $1547-20$ & $1.01486 \pm 0.00261$ & 15.0187 \\
\hline $1547-21$ & $1.02042 \pm 0.00263$ & 15.0193 \\
\hline $1547-22$ & $1.01625 \pm 0.00264$ & 15.0024 \\
\hline $1547-23$ & $1.01081 \pm 0.00257$ & 14.9833 \\
\hline $1547-24$ & $1.01480 \pm 0.00279$ & $14.984 \%$ \\
\hline $1547-25$ & $1.01074 \pm 0.00265$ & 14.9992 \\
\hline $1547-26$ & $1.00040 \pm 0.00249$ & 14.9688 \\
\hline $1547-27$ & $0.99617 \pm 0.00245$ & 14.9619 \\
\hline $1547-28$ & $1.00096 \pm 0.00244$ & 14.9507 \\
\hline $1547-29$ & $1.02132 \pm 0.00228$ & 14.9561 \\
\hline $1547-30$ & $1.01427 \pm 0.00258$ & 15.0171 \\
\hline $1547-31$ & $1.01583 \pm 0.00267$ & 15.0163 \\
\hline
\end{tabular}

-Value shown is for KENO-Va using Hansen-Roach cross sections. Uncertainty repcrted is 1 stanc ard deviation.

'16-energy-group, Hansen-Roach structure, $1 \sigma$ uncertainty is approximately 0.003 . 
Table A.11. Composition and atom densities of fuels and reflector for high-moderation, mixed-oxide critical experiments

\begin{tabular}{|c|c|c|c|c|}
\hline \multirow[b]{2}{*}{ Nuclide } & \multicolumn{4}{|c|}{ Atom density (atcom/brem)" } \\
\hline & $\begin{array}{c}426 \mathrm{~g} / \mathrm{L} \text { oxide; } \\
\text { atomic } \mathrm{H}:(\mathrm{U}+\mathrm{Pu})=47.4 ; \\
30.0 w \% \mathrm{Pu}\end{array}$ & $\begin{array}{c}660 \mathrm{~g} / \mathrm{L} \text { oxide; } \\
\text { atomic } \mathrm{H}:(\mathrm{U}+\mathrm{Pu})=30.6 ; \\
14.62 \text { wt } \% \mathrm{Pu}\end{array}$ & $\begin{array}{c}408 \mathrm{~g} / \mathrm{L} \text { oxide; } \\
\text { atomic } \mathrm{H}:(\mathrm{U}+\mathrm{Pu})=51.8 \\
7.89 \mathrm{wt} \% \mathrm{Pu}\end{array}$ & Reflector \\
\hline${ }^{211} \mathrm{Am}$ & $3.511 \times 10^{-7}$ & $4.036 \times 10^{-7}$ & $1.741 \times 10^{.7}$ & \\
\hline${ }^{29} \mathrm{Pu}$ & $2.578 \times 10^{4}$ & $1.954 \times 10^{4}$ & $6.528 \times 10^{-3}$ & \\
\hline${ }^{200} \mathrm{Pu}$ & $2.257 \times 10^{-5}$ & $1.702 \times 10^{-3}$ & $5.941 \times 10^{.6}$ & \\
\hline${ }^{241} \mathrm{Pu}$ & $1.756 \times 10^{-6}$ & $1.211 \times 10^{6}$ & $3.481 \times 10^{\prime}$ & \\
\hline 0 & $1.974 \times 10^{.3}$ & $3.023 \times 10^{-3}$ & $1.830 \times 10^{3}$ & $1.428 \times 10^{-2}$ \\
\hline${ }^{200} U$ & $6.604 \times 10^{4}$ & $1.252 \times 10^{.3}$ & $8.376 \times 10^{4}$ & \\
\hline${ }^{20 s} \mathrm{U}$ & $1.008 \times 10^{-5}$ & $1.904 \times 10^{.6}$ & $1.285 \times 10^{.6}$ & \\
\hline $\mathbf{H}$ & $4.468 \times 10^{-2}$ & $4.489 \times 10^{-2}$ & $4.719 \times 10^{.2}$ & $5.712 \times 10^{.2}$ \\
\hline $\mathbf{C}$ & $4.537 \times 10^{.2}$ & $4.412 \times 10^{.2}$ & $4.540 \times 10^{.2}$ & $3.570 \times 10^{-2}$ \\
\hline
\end{tabular}

1 barn $=10^{-24} \mathrm{~cm}$.

Table A.12. Criticality data for mixed-oxide assemblies containing 30 wt \% Pu with $\mathrm{H}:(\mathrm{Pu}+\mathrm{U})=47.4$

\begin{tabular}{|c|c|c|c|c||}
\hline \multirow{2}{*}{$\begin{array}{c}\text { Experiment } \\
\text { designation }\end{array}$} & Refiector & Length & Width & Height \\
\hline $1677-1$ & Plexiglas & 30.54 & 30.54 & 30.89 \\
\hline $1677-2$ & Plexiglas & 35.63 & 35.63 & 23.95 \\
\hline $1677-3$ & Plexiglas & 40.72 & 40.72 & 20.22 \\
\hline $1677-4$ & Plexiglas & 50.90 & 45.81 & 17.14 \\
\hline $1677-5$ & Plexiglas & 61.08 & 50.90 & 15.53 \\
\hline $1677-6$ & Plexiglas & 61.08 & 55.99 & 15.16 \\
\hline $1677-7$ & Plexiglas & 66.17 & 61.08 & 14.43 \\
\hline $1677-8$ & Plexiglas & 50.90 & 50.90 & 16.49 \\
\hline $1677-9$ & Bare & 45.81 & 40.72 & 37.98 \\
\hline $1677-10$ & Bare & 40.72 & 40.72 & 42.24 \\
\hline $1677-11$ & Bare & 45.81 & 50.90 & 32.49 \\
\hline
\end{tabular}


Table A.13. Criticality data for mixed-oxide assemblies containing 14.62 wt \% Pu with $\mathrm{H}:(\mathrm{Pu}+\mathrm{U})=30.6$

\begin{tabular}{||c|c|c|c|c|}
\hline \multirow{2}{*}{$\begin{array}{c}\text { Experiment } \\
\text { designation }\end{array}$} & Reflector & Length & Width & Height \\
\hline & Plexiglas & 30.54 & 40.72 & 29.81 \\
\hline $1677-12$ & Plexiglas & 40.72 & 40.72 & 23.84 \\
\hline $1677-13$ & Plexiglas & 45.81 & 50.90 & 19.82 \\
\hline $1677-14$ & Plexiglas & 50.90 & 50.90 & 18.92 \\
\hline $1677-15$ & Plexiglas & 61.08 & 50.90 & 17.72 \\
\hline $1677-16$ & Plexiglas & 61.08 & 61.08 & 16.63 \\
\hline $1677-17$ & Bare & 40.72 & 40.76 & 52.39 \\
\hline $1677-18$ & Bare & 40.72 & 45.86 & 45.10 \\
\hline $1677-19$ & Bare & 50.90 & 45.86 & 36.99 \\
\hline $1677-20$ & & & & \\
\hline
\end{tabular}

Table A.14. Calculated k-effectives for high-moderation, mixed-oxide critical experiments

\begin{tabular}{|c|c|c|}
\hline Experiment designation & k-effective & $\begin{array}{l}\text { Average energy group } \\
\text { for fissions }\end{array}$ \\
\hline $1677-01$ & $1.02477 \pm 0.00278$ & 14.9263 \\
\hline $1677-02$ & $1.01451 \pm 0.00299$ & 14.9141 \\
\hline $1677-03$ & $1.01987 \pm 0.00279$ & 14.9227 \\
\hline $1677-0.4$ & $1.01802 \pm 0.00284$ & 14.9362 \\
\hline $1677-05$ & $1.01897 \pm 0.00295$ & 14.9428 \\
\hline $1677-06$ & $1.01956 \pm 0.00305$ & 14.9474 \\
\hline $1677-07$ & $1.01923 \pm 0.00256$ & 14.9460 \\
\hline $1677-08$ & $1.01606 \pm 0.00286$ & 14.9359 \\
\hline $1677-09$ & $1.00541 \pm 0.00307$ & 14.6429 \\
\hline $1677-10$ & $1.00453 \pm 0.00298$ & 14.6434 \\
\hline $1677-11$ & $1.00126 \pm 0.00319$ & 14.6395 \\
\hline $1677-12$ & $1.02493 \pm 0.00291$ & 15.0215 \\
\hline $1677-13$ & $1.02348 \pm 0.00290$ & 15.0122 \\
\hline $1677-14$ & $1.02111 \pm 0.00282$ & 15.0246 \\
\hline $1677-15$ & $1.01779 \pm 0.00273$ & 15.0212 \\
\hline $1677-16$ & $1.02193 \pm 0.00282$ & 15.0300 \\
\hline $1677-17$ & $1.02112 \pm 0.00279$ & 15.0370 \\
\hline $1677-18$ & $1.02008 \pm 0.00283$ & 14.8003 \\
\hline $1677-19$ & $1.01874 \pm 0.00293$ & 14.7966 \\
\hline $1677-20$ & $1.01335 \pm 0.00290$ & 14.7958 \\
\hline
\end{tabular}

${ }^{2}$ Value shown is for KENO-Va using Hansen-Roach cross sections. Uncertainty reported is one standard deviation.

b16-energy-group, Hansen Roach structure, $1 \sigma$ uncertainty is approximately 0.003 . 
Table A.15. Average calculated k-effectives for high-moderation mixed-oxide critical experiments

\begin{tabular}{|c|l|c|}
\hline Fuel type & Reflector & Average k-effective \\
\hline $30 \mathrm{wt} \% \mathrm{Pu}$ & Plexiglas & 1.019 \\
\hline $30 \mathrm{wt} \% \mathrm{Pu}$ & Bare & 1.004 \\
\hline $14.6 \mathrm{wt} \% \mathrm{Pu}$ & Plexiglas & 1.022 \\
\hline $14.6 \mathrm{wt} \% \mathrm{Pu}$ & Bare & 1.017 \\
\hline
\end{tabular}

\section{A.4 INTERACTING ARRAY EXPERIMENTS}

Few array experiments were found which would be applicable to this problem. The most applicable data are documented in Ref. 12. An investigation of these experiments revealed that the uncertainty in the fuel distribution was so large as to make these data unusable.

\section{A.5 CONCRETE-REFLECTED EXPERIMENTS}

Appendix $\mathrm{C}$ contains a description of the composition of the cell wall concrete. The most applicable data are believed to be a series of experiments conducted with Fast Flux Test Reactor (FTR) pins immersed in water and reflected with concrete (Ref. 13) and a second series conducted with a water reflector. Critical experiment data for nine experiments are shown in Table A.16. The composition of the concrete reflector is shown in Table A.17. Also shown is the cell wall concrete composition from Appendix C. Even though the densities of the two mixtures are quite differe:t, the relative abundances of various elements are similar. Thus, a significant error in cross-section data for any of the constituents of the 3019 cell wall concrete might appear in the $k$-effective calculations for the critical experiments provided similar neutron spectra exist in both configurations. Any bias due to the presence of concrete can be isolated by comparing equivalent pitches for water and concrete reflected experiments. Calculated $\mathbf{k}$ effectives are reported in Table A.18.

Table A.16. Experimental criticality data for concrete reflected type 3.2 FTR fuel pins in water

\begin{tabular}{|c|c|c|c|c|c|c|}
\hline $\begin{array}{c}\text { Koponen } \\
\text { Citation ID }\end{array}$ & $\begin{array}{c}\text { PNL } \\
\text { Experiment } \\
\text { reference no. }\end{array}$ & $\begin{array}{c}\text { Square lattice } \\
\text { pitch }^{2} \text { (mm) }\end{array}$ & $\begin{array}{l}\text { Lattice width } \\
\text { (fuel pins) }\end{array}$ & $\begin{array}{l}\text { Critical } \\
\text { number of } \\
\text { fuel pins }\end{array}$ & $\begin{array}{l}\text { Critical } \\
\text { rows of } \\
\text { fuel pins }\end{array}$ & Reflector \\
\hline $2116-1$ & 010 & $9.53 \pm 0.13$ & 28 & $554 \pm 1$ & 19.79 & Concrete \\
\hline $2116-2$ & 007 & $12.64 \pm 0.13$ & 18 & $260 \pm 1$ & 14.44 & Concrete \\
\hline $2116-3$ & 012 & $15.41 \pm 0.13$ & 18 & $191 \pm 1$ & 10.61 & Concrete \\
\hline $2116-4$ & 011 & $19.06 \pm 0.18$ & 14 & $152 \pm 1$ & 10.86 & Concrete \\
\hline $2117-1$ & 021 & $0.968 \pm 0.001$ & 25 & $571.9 \pm 0.2$ & 22.88 & Water \\
\hline $2117-9$ & 043 & $1.242 \pm 0.001$ & 20 & $293.9 \pm 0.1$ & 14.70 & Water \\
\hline $2117-17$ & 013 & $1.537 \pm 0.001$ & 15 & $196.7 \pm 0.2$ & 13.11 & Water \\
\hline$\cdots$ & $068 \mathrm{R}$ & $1.537 \pm 0.001$ & 15 & $199.7 \pm 0.3$ & 13.31 & Water \\
\hline $2117-25$ & 032 & $1.935 \pm 0.002$ & 15 & $165.1 \pm 0.4$ & 11.01 & Water \\
\hline
\end{tabular}

'Error limits shown are standard deviations and are for the indicated measured parameter only. 
Table A.17. Comparison of concrete compositions

\begin{tabular}{|c|c|c|}
\hline \multirow{2}{*}{ Chemical element } & \multicolumn{2}{|c|}{ Wt \% in concrete } \\
\cline { 2 - 3 } & Critical experiments & 3019 cell walls \\
\hline $\mathrm{Al}$ & $2.32 \pm 0.01$ & $2.26 \pm 0.15$ \\
\hline $\mathrm{Ca}$ & $7.27 \pm 0.28$ & $7.51 \pm 0.28$ \\
\hline $\mathrm{Fe}$ & $0.28 \pm 0.02$ & $1.40 \pm 0.03$ \\
\hline $\mathrm{Si}$ & $34.68 \pm 0.39$ & $38.19 \pm 1.21$ \\
\hline $\mathrm{Mg}$ & $1.45 \pm 0.05$ & $0.31 \pm 0.03$ \\
\hline $\mathrm{K}$ & $0.75 \pm 0.15$ & $0.92 \pm 0.26$ \\
\hline $\mathrm{Na}$ & $0.17 \pm 0.01$ & $0.24 \pm 0.03$ \\
\hline $\mathrm{O}$ & $52.26 \pm 0.58$ & $48.01 \pm 1.56$ \\
\hline $\mathrm{H}$ & $0.82 \pm 0.07$ & $0.50^{\mathrm{d}}$ \\
\hline $\mathrm{C}$ & $-\cdots$ & $0.50^{\mathrm{d}}$ \\
\hline $\mathrm{S}$ & $\cdots-$ & $0.08 \pm 0.02$ \\
\hline
\end{tabular}

"Errors are $1 \sigma$ standard deviations based on three analyses.

bensity of conrete immersed in water $=2.452 \mathrm{~g} / \mathrm{cm}^{3}$.

'Density of cell wall concrete $=1.523 \pm 0.036 \mathrm{~g} / \mathrm{cm}^{3}$.

${ }^{\mathrm{D}}$ Maximum value assumed from Appendix $\mathrm{C}$.

Table A.18. Calculated parameters for arrays of FTR pins

\begin{tabular}{|c|c|c|c|c|}
\hline Koponen Citation ID & Pitch $(\mathbf{c m})$ & Reflector & K-effective & Avg. fission group \\
\hline $2117-1$ & 0.968 & water & $0.98491 \pm 0.00286$ & 13.61 \\
\hline $2117-9$ & 1.242 & water & $0.99373 \pm 0.00339$ & 14.48 \\
\hline $2117-7$ & $1.537^{a}$ & water & $0.99217 \pm 0.00318$ & 14.89 \\
\hline- b $^{\mathrm{b}}$ & $1.537^{\mathrm{c}, \mathrm{d}}$ & water & $0.99522 \pm 0.00303$ & 14.88 \\
\hline $2117-25$ & 1.935 & water & $1.00712 \pm 0.00304$ & 15.18 \\
\hline $2116-1$ & 0.953 & concrete & $0.99199 \pm 0.00267$ & 13.53 \\
\hline $2116-2$ & 1.264 & concrete & $1.00091 \pm 0.00327$ & 14.52 \\
\hline $2116-3$ & 1.541 & concrete & $1.00409 \pm 0.00306$ & 14.90 \\
\hline $2116-4$ & 1.906 & concrete & $1.01019 \pm 0.00303$ & 15.16 \\
\hline
\end{tabular}

'PNL experiment number 013.

${ }^{b}$ Computer input dataset designated 2117.X.

${ }^{\circ}$ PNL experiment number 068r.

${ }^{\mathrm{d}}$ Average k-effective for $1.537 \mathrm{~cm}$ pitch is $0.993769 \pm 0.002194$. 
For comparable pitches, average fission group values are in excellent (with $1 \%$ ) agreement. While the calculated k-effectives for concrete reflected experiments are slightly higher than comparable water reflected cases, comparison of the differences using student's $t$ test reveals that the differences are not significant.

Considering the range of average fission group values, the presence of concrete as a moderator and reflector in intercell 2 and 3 configurations should not lead to any bias in k-effective under nominal conditions. Applicable data do not exist for credible abnormal conditions but extrapolation from existing data does not yield any trends.

\section{A.6 STATISTICAL ANALYSES OF CRITICAL EXPERIMENTS}

The data presented in Sect. A.3 were grouped into various categories and tested for trends and biases. The first procedure was to simply calculate the means of the various data sets and visually inspect them for trends. Table A.19 shows the calculated mean value of $k$-effective for the various series of experiments.

Table A.19. Categorized mean calculated k-effectives

\begin{tabular}{||c|c|}
\hline \multicolumn{1}{|c|}{ Category } & Mean value of k-effective \\
\hline All experiments & 1.009 \\
\hline All 1453 experiments & 0.996 \\
$\mathrm{Pu} \%=29.3, \mathrm{H} / \mathrm{X}=2.8, \mathrm{Pu}-240=11.5 \%$ & 0.997 \\
$\mathrm{Pu} \%=15, \mathrm{H} / \mathrm{X}=2.86, \mathrm{Pu}-240=11.5 \%$ & 0.990 \\
\hline All 1.547 experiments & 1.008 \\
$\mathrm{Pu} \%=30.3, \mathrm{H} / \mathrm{X}=2.8, \mathrm{Pu}-240=11.5 \%$ & 0.999 \\
$\mathrm{Pu} \%=14.6, \mathrm{H} / \mathrm{X}=30.6, \mathrm{Pu}-240=7.97 \%$ & 1.011 \\
\hline All 1677 experiments & 1.017 \\
$\mathrm{Pu} \%=30.0, \mathrm{H} / \mathrm{X}=47.4, \mathrm{Pu}-240=8 \%$ & 1.015 \\
$\mathrm{Pu} \%=14.62, \mathrm{H} / \mathrm{X}=30.6, \mathrm{Pu}-240=8 \%$ & 1.020 \\
\hline All Bare & 1.004 \\
\hline All Plexiglas Ref. & 1.010 \\
\hline
\end{tabular}

Considering all the data as a group, a $1 \%$ bias exists in calculated $k$-effective. In order to quantitatively examine the calculations for trends, some statistical analyses were performed with the SAS procedure CORR. ${ }^{14}$ A search for a linear relationship between a given variable and calculated k-effective was performed by calculating the Pearson product moment correlation and its level of significance. If a variable, $x$, can be expressed exactly as a linear function of another variable, $y$, then the correlation is 1 or -1 depending on whether the two variables are directly related or inversely related. The lower the value of the significance level, the higher the degree of confidence that the computed correlation value represents a true phenomena. Calculated product moments for the critical experiment parameters are presented in Table A.20. All of the values in Table A.20 have a high degree of confidence.

It should be noted that there is no physical reason to suspect that k-effective would be correlated in any way with any of the parameters listed in Table A.16. The justification for selecting the product moment formulation is simply observation of the trends summarized in Table. A.19. 
Considering the first four entries of Table A.20, it appears that k-effective is directly correlated with $\mathrm{H} /(\mathrm{Pu}+\mathrm{U})$ ratio and average fission group and inversely correlated with the quantity of $\mathrm{Pu}-240$ in the plutonium. Note, however, that average fission group and $\mathrm{H} /(\mathrm{Pu}+\mathrm{U})$ ratio are strongly correlated. Intuitively, it is obvious that both of these correlations represent the same physical phenomena - degree of moderation in the system.

The strong negative correlation between $\mathrm{H} /(\mathrm{Pu}+\mathrm{U})$ ratio and ${ }^{240} \mathrm{Pu}$ content reveals a need for additional experimental data if one is to discern whether $k$-effective is correlated to either a degree-of-moderation parameter or to ${ }^{240} \mathrm{Pu}$ content or both. Note that examination of plutonium oxide critical experiments and/or low plutonium content mixed mixed oxide experiments might resolve this situation.

For this study, it was decided to correlate k-effective with average fission group. Among the correlations to k-effective, the value for average fission group was largest. Perhaps more importantly, in all the criticality safety calculations for Intercell 2 and 3 storage wells, the ${ }^{240} \mathrm{Pu}$ content was assumed to be zero. This assumption is conservative since maximum reactivity is derived from assuming that all plutonium is present as ${ }^{239} \mathrm{Pu}$ but the safety limit, derived subsequently, is based on critical experiments which have been conducted with fuels ranging in ${ }^{200} \mathrm{Pu}$ content from $8-11.5 \%$. Note in Table 2 , that most of the NFS waste contains $8.3 \mathrm{wt} \%{ }^{240} \mathrm{Pu}$ in the plutonium.

Table A.20. Calculated Pearson product moment correlation coefficients for KENO-Va, Hansen-Roach calculations

\begin{tabular}{||l|c|c|}
\hline \multicolumn{1}{|c|}{ Correlated variables } & Correlation coefficient & Significance level \\
\hline \hline Average fission group, k-eff & .765 & .0001 \\
\hline${ }^{200} \mathrm{Pu} / \mathrm{Total} \mathrm{Pu}, \mathrm{k}$-eff & -.753 & .0001 \\
\hline $\mathrm{Pu} /(\mathrm{Pu}+\mathrm{U}), \mathrm{k}$-eff & -.421 & .0007 \\
\hline $\mathrm{H} /(\mathrm{Pu}+\mathrm{U}), \mathrm{k}$-eff & .699 & .0001 \\
\hline $\mathrm{H} /(\mathrm{Pu}+\mathrm{U})$, average fission group & .898 & .0001 \\
\hline $\mathrm{H} /(\mathrm{Pu}+\mathrm{U}),{ }^{200} \mathrm{Pu}$ & -.917 & .0001 \\
\hline
\end{tabular}

From Table A.16, reflectors appear to add a positive bias to calculated k-effectives. Note, however, that the 3019 Intercell 2 and 3 wells have large concrete reflectors.

Correlating with average fission group allows the moderation provided by interstitial concrete in Intercell Storage 2 and 3 to be compared to the polystyrene moderated and reflected oxide critical experiments. A plot of k-effective versus average fission group is given in Fig. A.1. Note that the expected average fission group value for the NFS waste under "normal" conditions would be 12-13, within the range spanned by the critical experiment data. The average fission group values for all credible abnormal conditions considered also are within the range of the data.

A linear regression of $k$-effective to average fission group, AFG, was performed and the resulting linear function was

$$
\text { k-effective }=0.957397+0.003797 \text { (average Hansen-Roach fission group) }
$$

The $\mathbf{R}^{2}$ value (goodness-of-fit) was 0.601 . This equation is plotted as a solid line in Fig. A.1. Inclusion of all of the other variables noted in Tables A.19 and A.20 into the correlation yielded an insignificant increase in the $R^{2}$ value to 0.680 . 


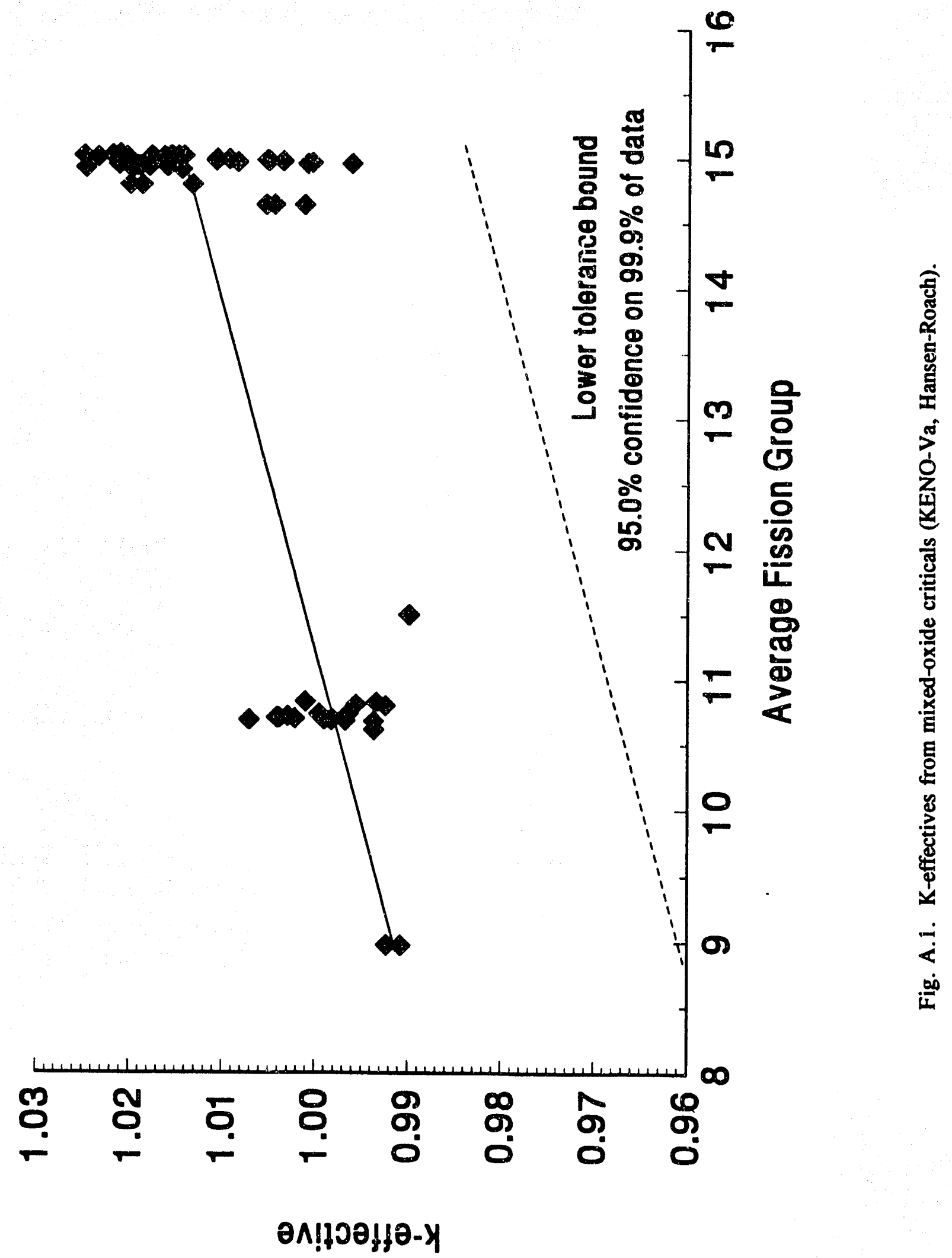


Note that correlating k-effective to powers of the AFG values - specifically the cube of these values yielded correlations with the same $R^{2}$ values but with significantly higher y intercepts ( $k$-eff $=0.988$ at average fission group of 1 ). This finding would be important if it were necessary to extrapolate beyond the range of the critical experiment data.

Also shown in Fig. A.1 is a dashed line representing the lower tolerance bound for inclusion of $99.9 \%$ of the calculated $k$-effectives at the $95 \%$ confidence level. The equation of this line is $k$-effective $=$ $0.92674+0.003797$ (average Hansen-Roach fission group). The derivation of the tolerance bound is based on the treatment presented in Refs. 15-17. Note that for nominal NFS conditions, a k-effective of 0.97 yields a tolerance bound of at least $99.9 / 95$.

Earlier in the report it was noted that possible negative biases exist regarding the presence of copper plates in critical experiments or the absence of a reflector. Nevertheless, these experiments have been retained in the database shown in Fig. A.1 because their impact is conservative (leads to a lower tolerance bound).

\section{A.7 CORRECTIONS TO DERIVED SUBCRICALITY LIMITS TO ACCOUNT FOR UNCERTATNTIES IN EXPERIMENTAL MEASUREMENTS}

The critical experiments parameters that are input to the SCALE calculations have associated uncertainties. The impact of these uncertainties must be accommodaied in the margin of subcriticality. Yet, it would be untractable to examine the impact of every experimental uncertainty on each of the critical experiments examined in this study. Consequently, two experiments were selected for study.

Experiment $1453-10$ is the !ow-moderation-oxide experiment with the minimum critical height. Uncertainty in the critical height should have the greatest impact in the minimum height configuration. Likewise, experiment 1677-7 has the minimum critical height for the high-moderation experiments. Selecting these two experiments allowed for observation of impact of uncertainties over the range of moderation available. An assessment of possible experimental errors and comments are provided in Table A.21.

Table A.21. Sources of experimental uncertainties

\begin{tabular}{||l|l||}
\hline \multicolumn{1}{|c|}{ Source } & \multicolumn{1}{|c|}{ Remarks } \\
\hline Measured size of oxide blocks & Uncertainties provided by experimenters \\
\hline Extrapolation of critical thickness of final row & Uncertainties provided by experimenters \\
\hline Density of fuel & Uncertainties provided by experimenters \\
\hline Isotopic ratios & $\begin{array}{l}\text { Uncertainties provided by experimenters, } \\
\text { Appendix B. }\end{array}$ \\
\hline Impurities in fuel & $\begin{array}{l}\text { Spark source check performed by experimenters, } \\
\text { but no data available for calculations. }\end{array}$ \\
\hline Moderator density in fuel & Uncertainties provided by experimenters \\
\hline Reflector impurities & $\begin{array}{l}1960 \text { 's plexiglas, no fire-retarding agents present, } \\
\text { spark source check performed but no data available } \\
\text { for calculations }\end{array}$ \\
\hline
\end{tabular}


Most of the experimental uncertainty data were reported in the references containing the critical experiment data. However, some data regarding uncertainty in the plutonium concentration were obtained from the log books for the experiments. A letter proyides reference for these data and is included as Appendix B.

Where possible, the uncertainties noted in Table A.21 were investigated. Because of cost considerations, these investigations were not performed with verified software. However, since only perturbations from a reference case were being investigated, this is not believed to be a problem, especially in light of the results which are presented in Table A.21.

If the experimental uncertainties have no impact on calculated $k$-effectives, all the differtnces reported on the right-hand side of Table A.22 should be zero. One can use student's $t$ distribution ${ }^{18}$ to determine whether the calculated differences are significantly different from zero. Defining the $t$ statistic to be

$$
t=\frac{\text { difference }_{\mathrm{i}}-0}{\sigma_{i}},
$$

and assuming one degree of freedom then for the "worst case," in Tab!e A.22, $t=0.00403 / 0.00215=$ 1.874. The probability of $t>1.874$ is 0.19 . Thus, it is unlikely that, taken independently, the experimental uncertainties have any statistically significant impact on calculated $k$-effectives. Considering that not all experimental uncertainties were well-known (see Table A.20), a reactivity bias of 0.01 to account for these unknowns should be quite conservative.

\section{A.8 COMMENTS ON APPLICABILITY OF CRITICAL EXPERIMENTS AND MARGIN OF SUBCRITICALITY}

It has been stated previously that the actinide conient, moderator content, and physical form of the materials in the critical experiments are representative of the waste expected to be stored in the Intercell 2 and 3 wells. It has also been noted that the span of the values of the average fission group (afg) for the critical experiments includes the range expected to exist for normal and credible abnormal configurations in the storage wells. It seemed possible, however, for two configurations to have the same afgs but have different neutron spectra. Consequently, qualitative comparisons of spectra were made and are shown in Figs. A.2 and A.3.

As noted in Sect. 6.3, the "normal" storage configuration has an afg of 13.2. The two critical experiments whose afg values are closest to the normai configuration are 1453-11 $(\mathrm{afg}=11.5)$ and $1677-11$ (afg =14.64). Note that $1453-11$ is a methacrylate-plastic-reflected experiment and $1677-11$ is a "bare" experiment.

For all the fast and epithermal groups, shown in Fig. A.2, the fission fraction for the storage configuration lies between the two experiments. The storage configuration appears to have a more thermalized spectra than either of the critical experiments, but the overall spectral shape is similar.

Spectra for the abnormal configuration corresponding to Case 6 in Table 10 is shown in Fig. A.3. The afg value for this case, 9.2 , is the lowest of all calculated abnormal configurations. Experiment 1453-01 has an almost identica! afg - 9.0.

The shapes of the two spectra in Fig. A.3 are quite similar. All significant peaks in groupwise fission fraction for the storage case are matched in the critical experiment spectra. 
The spectral comparisons in Figs. A.2 and A.3, taken with previous comparisons of fuel composition and moderator content, provide support for the conclusion that the storage configurations which have been evaluated are within the range of applicability defined by the critical experiments. Given the relatively large number of experiments, the small variability among calculated k-effectives for the experiments, and the well-defined storage configuration being considered, there seems to be no need to apply an additional subcritical margin to the corrected (for experimental uncertainties) tolerance bound derived in Sect. A.6. Note that other, undefined, mixed-oxide storage configurations might not satisfy these criteria and would require an additional subcritical margin applied to the corrected tolerance bound.

During safety reviews, it is sometimes questioned as to the degree of subcriticality to which a particular configuration is designed. Using results $\mathrm{fl} \cdot \mathrm{m}$ Sects. 6.6, 6.7 and Table 10 , the degree of subcriticality for Intercell 2 and 3 storage wells for NFS waste is at least $0.447(0.96-0.01-0.453=0.447)$. 


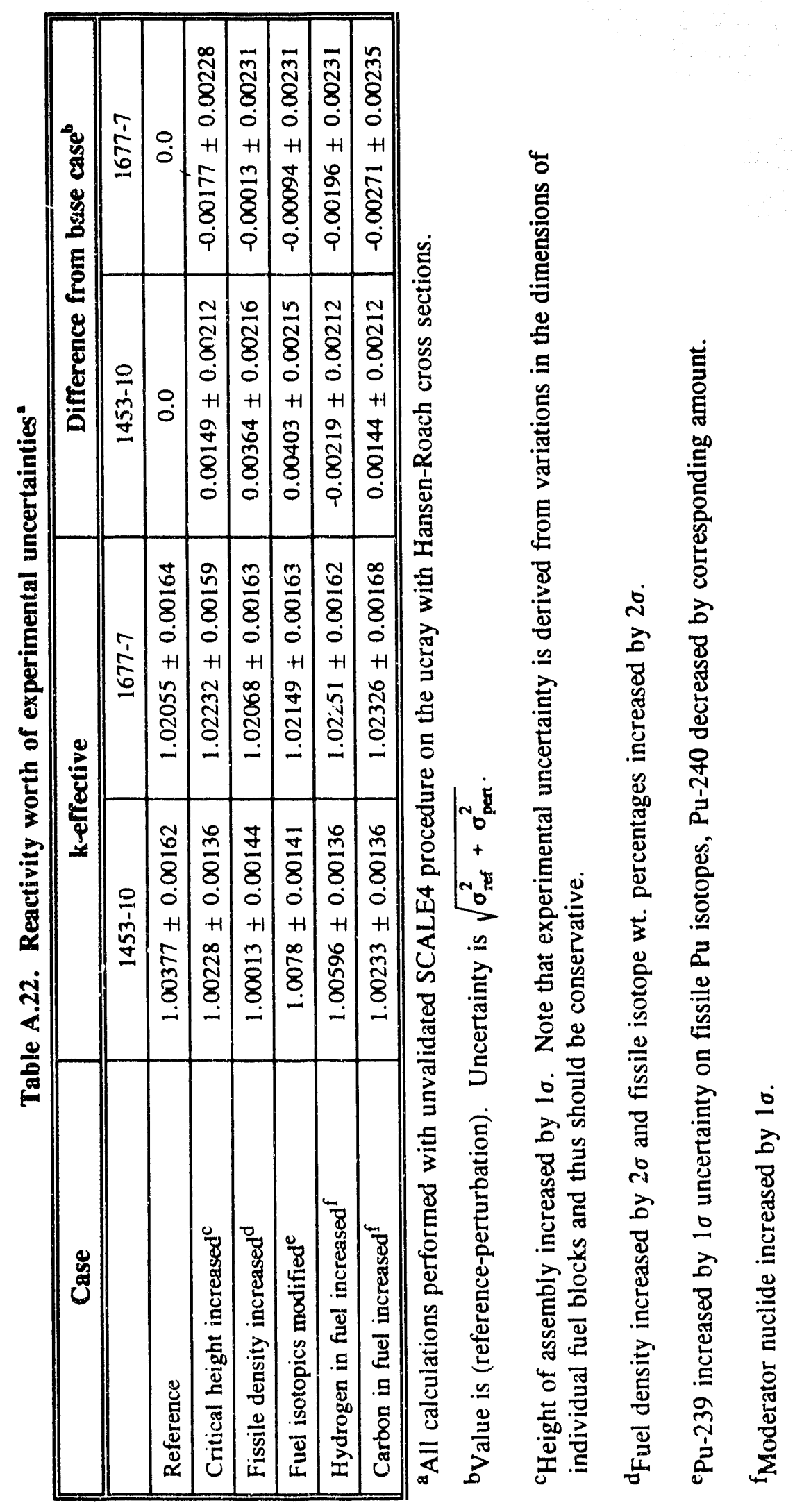




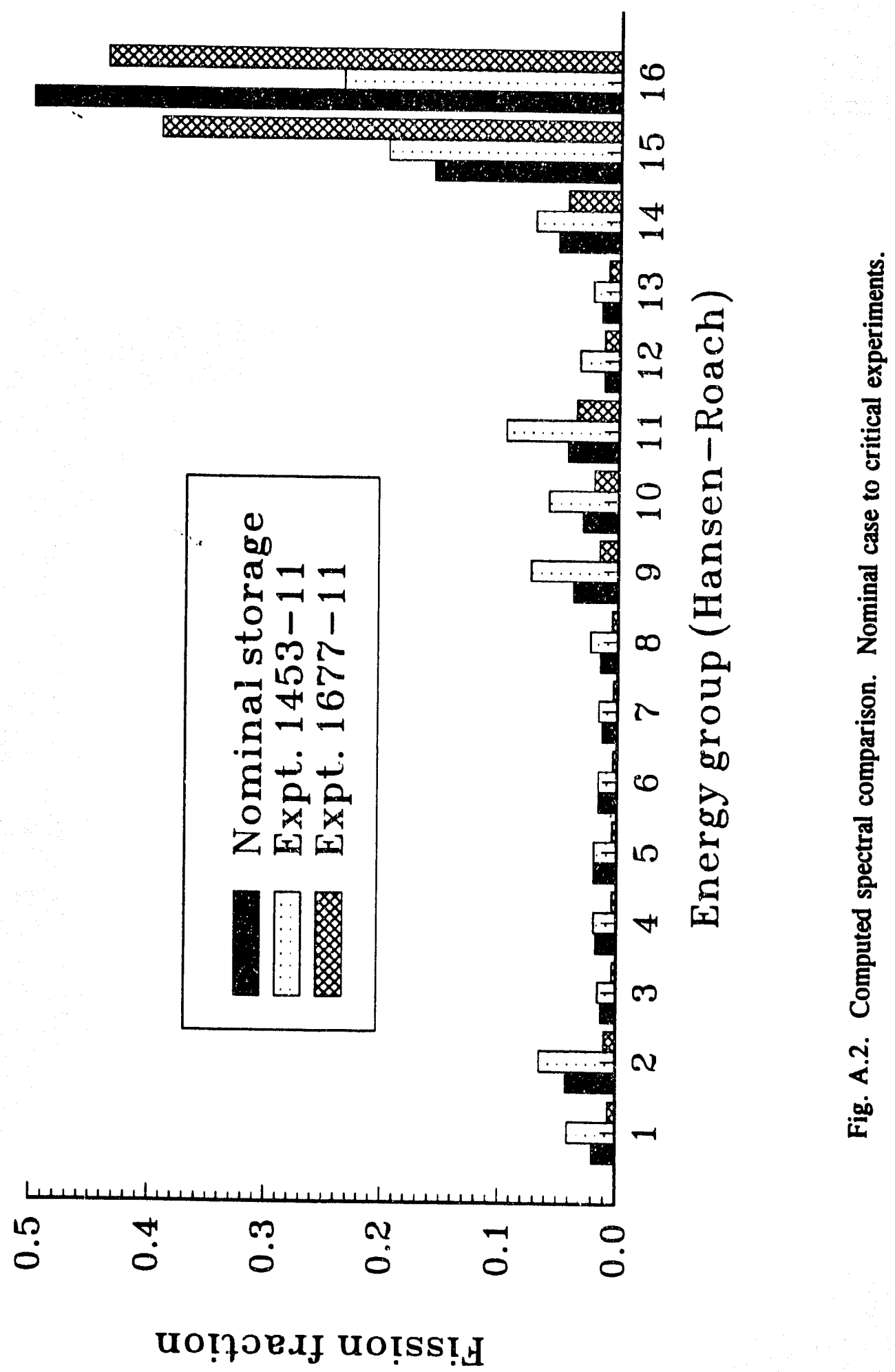




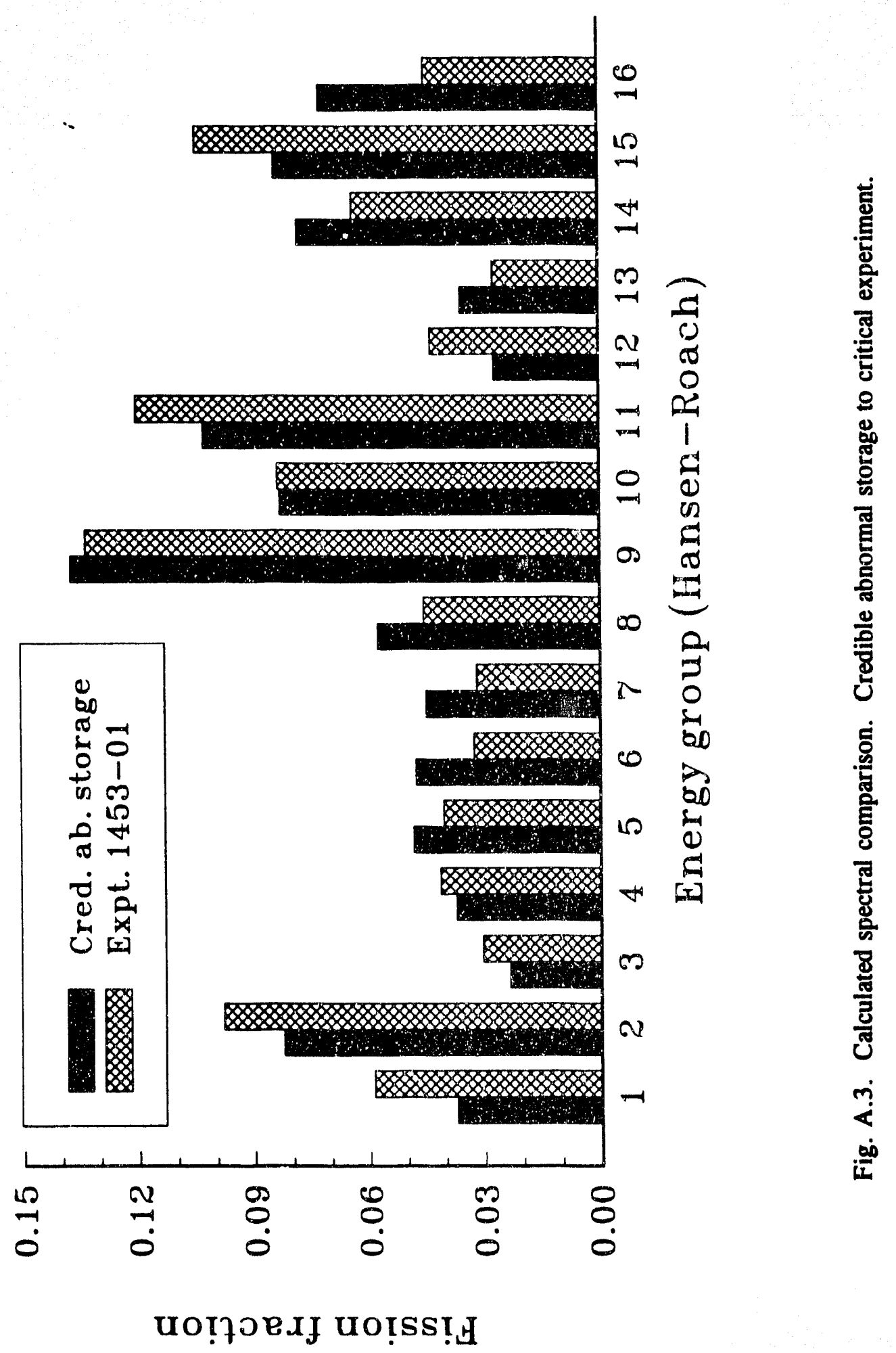




\section{REFERENCES FOR APPENDIX A}

1. S. R. Bierman and E. D. Clayton, "Critical Experiments with Low-Moderated Homogeneous Mixtures of Plutonium and Uranium Oxides Containing 8, 15, and 30 wt \% Plutonium," Nucl. Sci. Eng. 61, 370-76 (1976).

2. S. R. Bierman and E. D. Clayton, "Critical Experiments to Measure the Neutron Poisoning Effects of Copper and Copper-Cadmium Plates," Nucl. Sci. Eng. 55, 58-66 (1974).

3. R. C. Lloyd, S. R. Bierman, and E. D. Clayton, "Criticality of Plutonium-Uranium Mixtures Containing 5 to 8 wt \% Plutonium," Nucl. Sci. Eng. 55, 51-57 (1974).

4. S. R. Bierman, E. D. Clayton, and L. E. Hansen, "Critical Experiments with Homogeneous Mixtures of Plutonium and Uranium Oxides Containing 8, 15, and $30 \mathrm{~W} \%$ Plutonium," Nucl. Sci. Eng. 50, 115-26 (1973).

5. G. E. Hansen and W. H. Roach, Six and Sixteen Group Cross Sections for Fast and Intermediate Critical Systems, LAMS-2543, December 1961.

6. SCALE - A Modular Code System for Performing Stundardized Computer Analyses for Licensing Evaluation, NUREG/CR-0200, Rev. 4 (ORNL/NUREG/CSD-2/R4), Vols. I, II and III (draft February 1990). Available from Radiation Shielding Information Center, Oak Ridge National Laboratory, as CCC-545.

7. S. R. Bierman and E. D. Clayton, "Critical Experiments with Mixed Oxides of Pu and U Containing 8 and 30 wt \% Plutonium," Trans. Am. Nucl. Soc. 15, 307-309 (1972).

8. S. R. Bierman and E. D. Clayton, "Critical Experiments with Low Moderated Homogeneous Mixtures of Plutonium and Uranium Containing 8 and $15 \mathrm{Wt} \%$ Plutonium," Trans. Am. Nucl. Soc. 23, 235-37 (November 1976).

9. S. R. Bierman, R. C. Lloyd, and E. D. Clayton, "Critical Experiments to Measure the Neutron Poisoning Effects of $\mathrm{Cu}$ and Cu-Cd Plates," Trans. Am. Nucl. Soc. 17, 265 (1973).

10. S. R. Bierman, "Critical Experiments-Benchmarks (Pu + U Systems)," Nucl. Technol. 26, 35281 (July 1975).

11. S. R. Bierman and E. D. Clayton, "Critical Experiments with Mixed Oxides of Pu and U Containing 15 and $30 \mathrm{Wt} \%$ Pu," Trans. Am. Nucl. Soc. 14, 40-41 (June 1971).

12. J. T. Thomas, "Critical Experiments with UF 6 Cylinder Model 8A Containers," Y-DR-128 (September 1974).

13. B. M. Durst, et al., "Summary of Experimental Data for Critical Arrays of Water Moderated Fast Test Reactor Fuel," PNL-3313, ORNL/Sub-81/97731/7, May 1981. 


\section{REFERENCES (continued)}

14. J. P. Sall and D. M. Delong, "The CORR Procedure," SAS User's Guide: Basics 1982 Edition, 501-512, SAS Institute, Inc. (1982).

15. H. R. Dyer, W. C. Jordan, and V. R. Cain, "A Technique for Code Validation for Criticality Safety Calculations," Trans. Am. Nucl. Soc., 63, pg. 238-239 (June 1991).

16. D. C. Bowden and F. A. Graybill, "Confiderce Bands of Uniform and Proportional Width for Linear Models," Am. Stat. Assoc. J., 61, 182 (March 1966).

17. D. C. Bowden, "Query, Tolerance Interval in Regression," Technometrics 10, 207-209 (February 1968).

18. G. E. P. Box, W. G. Hunter, and J. S. Hunter, Statistics for Experimenters (1978). 


\section{APPENDIX B}

UNCERTAINTIES IN ACTINIDE CONTENT FOR LOW-MODERATED OXIDE CRITICAL EXPERIMENTS 
June 29, 1992

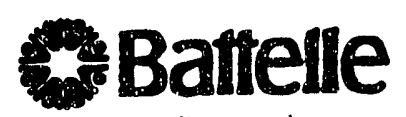

Pacific Northwest Laboratories Resrette Boulonard

P.O. Box 990

Rlchland. Wushimaton 99352

Tatephont foten

$376-9589$

Facsimile:

Verification:

(509) 376-9200

(509) 376-9589

Mr. Trent Prim

ORNL

MS-0363

P.0. Box 2008

Oak Ridge, TH 37831-6370

Dear Trent:

As we discussed by phone today, I have enclosed the Pu isotopic analyses for the three batches of oxides used in the 11.5-30-3 mixed oxide fuel. As coupacts ware made from each batch of oxide a composfte sampie was accumiated. The onelosed analyses are the results obrained on ach composite sariple.

Although the wighted aymrge one sigwa deyiatfon quated in the report reflects the spread in the compositfon between batches, the experimental axsenbly was hougeneous aix of these batehes. Therefore, I agree with you that the error ifmits should be based on those quoted in the three analyses. Fortuniately these are casential the same for all three batchins.

I have also enclosed copies of the uranium isotopic analyses obtained from two samples. However, there should not be a similar probiem since all of the uraniu came from the same source.

Sincerely Yours.

S.R. Bierman

Staff Scientist

Reactor Systems Analyses 
WADCO

Corporatioǹ

\section{$1453 \exp 15$}

From: Applifed Chemistry and Analysis

Dowe: Noventer 29, 1977

ISOTOPIC ARALYSIS OF PLUTONIUM

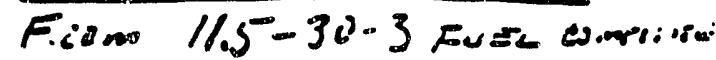

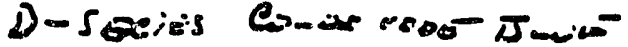

TO: R. R. King, Jr. Sidf Summan

C6: Moheen

File

$$
45 \% \text { ce }=1.96 r
$$

H. S.

Lab. No.

Cust. I. 0. $127777 \quad P-3170$

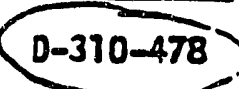

AR HCD
OXIDC ve. $8+\frac{1}{9}-i s .5$ $238=0.088+0.004 \quad 0.0885 .0$ int $239=85.67 \pm 0.06 \quad 85.76 / 8.08$ $240=11.53 \pm 0.06 \quad 11.5+25.01$ $261=2.32 \pm 0.01 \quad 2.5225 .01$ $242=\frac{0.286}{99.874} \pm 0.009 \frac{0.286 \pm .00^{\circ}}{49.997}$

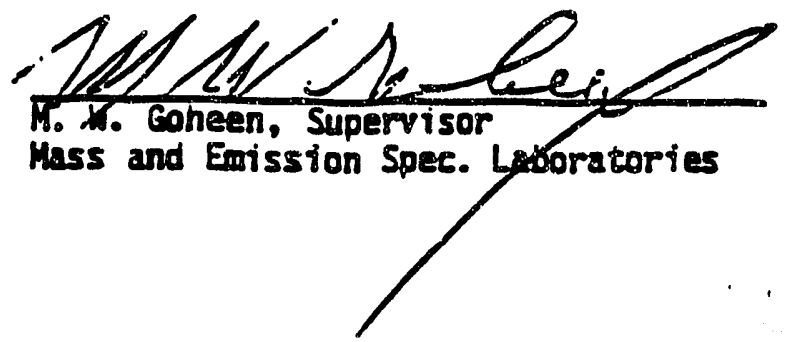




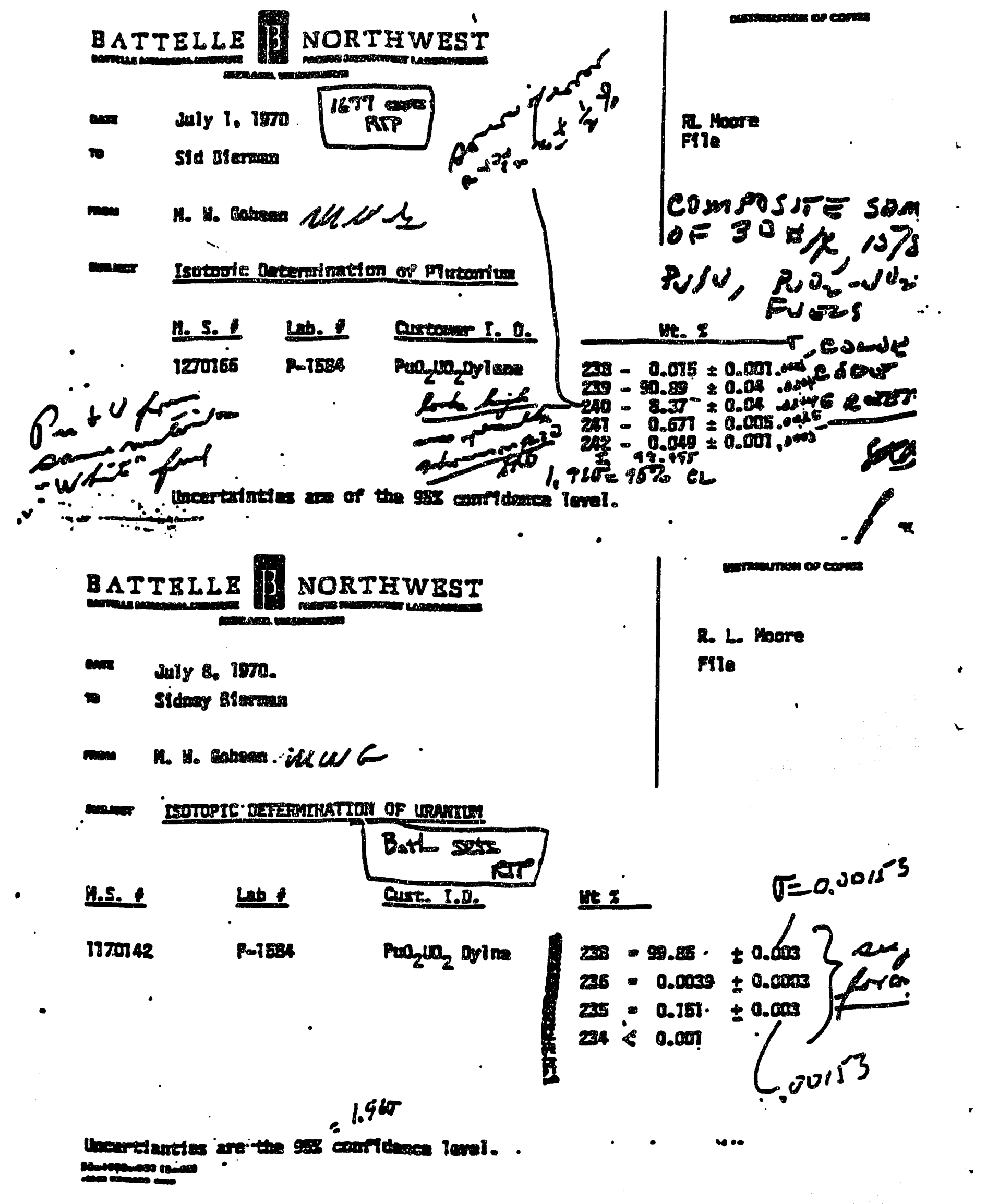


BAYTELLE PI NORTHWEST

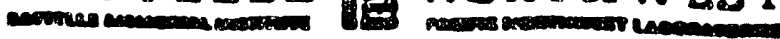

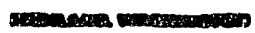

Noweromers 19. 9969

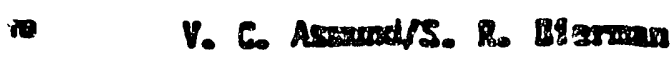

1677 exps.

IM Trathes

File

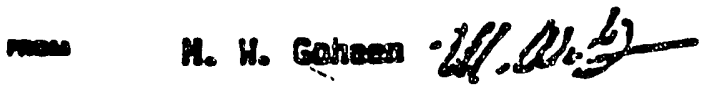

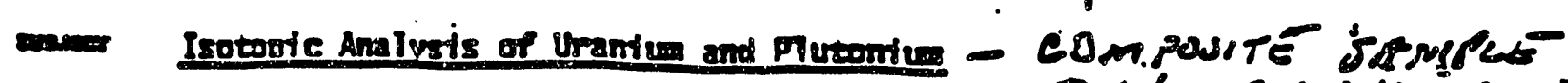

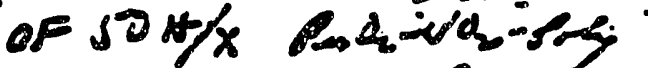

Putoriun

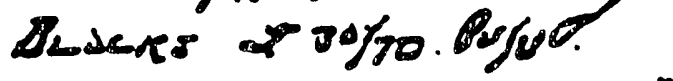

\begin{tabular}{|c|c|c|c|c|c|}
\hline AS: & Des 1 & Aretouser I. D. & Mointint & & \\
\hline 724.0245 & 3025 & $\begin{array}{l}221-21200 \text { E } \\
8-45317\end{array}$ & $\begin{array}{r}220=9.38 \\
-210=8.00\end{array}$ & $\begin{array}{l}+0.04 \\
00.04\end{array}$ & 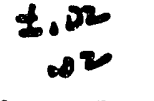 \\
\hline
\end{tabular}

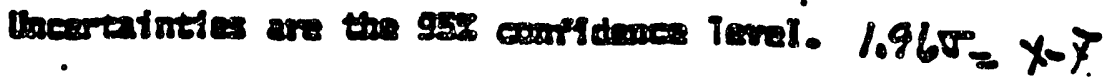

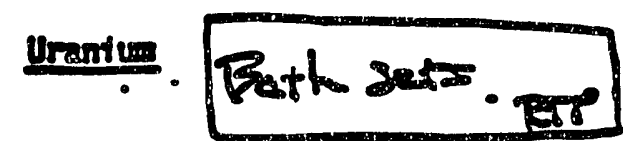

. 51 dite congener I. D.

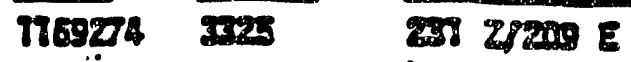

Peinter 8

r

$208=58.846 \pm 0.002 \pm 0,0010$.

P-43257

..$\quad \mathrm{PuO}_{2} \mathrm{OH}_{2}$

$2015=0.0042=0.0004+0.000^{2}$

$225=0.251$.

: . Bolyotortane

$20 \% 20.007$

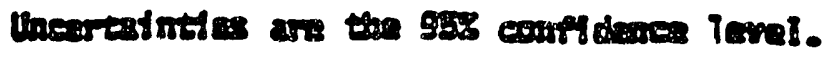<smiles>[CH+]1CC1</smiles>

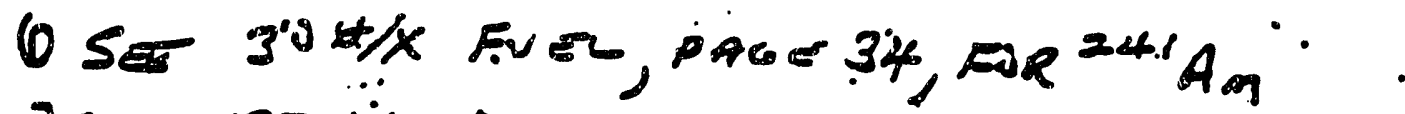

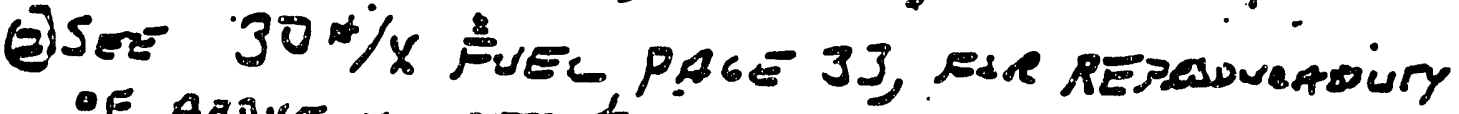

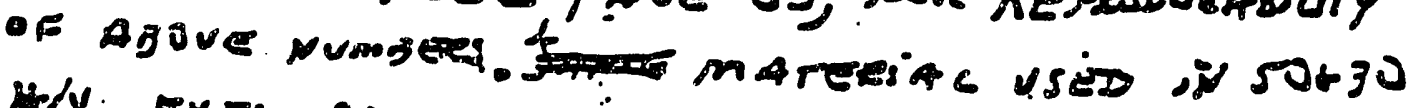

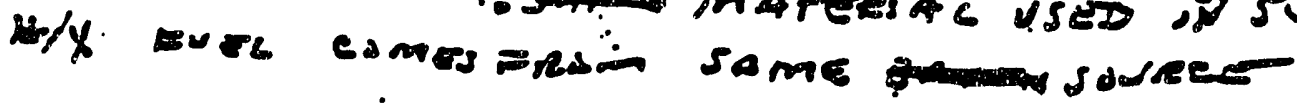

rimiono.

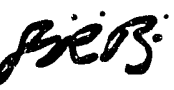

80mancon 


\section{APPENDIX C}

CONCRETE COMPOSITION IN CELL WALLS OF BUILDING 3019 


\section{APPENDIX C \\ CONCRETE COMPOSITION IN CELL WALLS OF BUILDING 3019}

Four samples were sent for analyses. Sample number P25 pit wall was sent as a standard and does not reflect the composition of 3019 cell walls. Data from the three RM samples were averaged to determine cell wall atom densities. Figure C. 1 is the report of the concrete analyses as supplied by Galbraith Laboratories.

Figure C. 2 shows the FORTRAN program used to calculate atom densities. Figures C. 3 and C.4 show the program input and output, respectively. Note that all percentages were confirmed by Galbraith Laboratories to be wt \% and that the unreported constituent of the concrete samples was confirmed by A. M. Krichinsky, ORNL. Chemical Technology Division, to be oxygen. Note that atom densities are in units of atoms $/(\mathrm{bn} \cdot \mathrm{cm})$.

From the data shown in Fig. C.1, it is apparent that sample 4 differs from the other RM samples. Inspection re ealed that the $\mathrm{Si}$ content of the third $\mathrm{RM}$ sample is much lower than that of the first two samples. Galbraith Laboratories was ssked to reevaluate Sample 4 and provide an update to A. M. Krichinsky. Sample 4 was reanalyzt: twice, and the silicon content was reported to be 37.48 and $36.27 \mathrm{wt} \%$ respectively (average $=36.875$ ). This average value was used along with the other weight percentages reported in Fig. C.1 to calculate atom densities shown in Fig. C.4.

Sensitivity studies showed that maximum reactivity was obtained with minimum water content. Because only an upper limit was provided for hydrogen, a second set of atom densities was generated with the hydrogen conients of all three samples set to zero. For the no hydrogen case, the atom density of oxygen increases from that shown in Fig. C. 4 to $2.78196 \times 10^{-2}$.

The bulk density measurement was performed using gravimetric techniques and has a reported accuracy of $0.001 \mathrm{~g} / \mathrm{ml}$ ( $1 \sigma$ value). The weight fractions were determined using an inductively coupled plasma analysis technique which has a $2 \sigma$ uncertainty of $5 \%$ of the analyzed value for higher weight percentage measurements ( $>$ a few weight percent) and $10 \%$ of the analyzed value for lower weight percentage measurements. Note that sampling differences usually exceed these uncertainties. 


\section{GAIBRAIITIII}

\section{Laforatories, Inic}

QUANTITATIVE MICROANALYSES

ORGANIC - INORGANIC

FHONE ELI/546-1335 FAX EE/546-7209

Vis. Marion Fergonow

Onk Rldge natiomi Iab 45005

Pant Orf1en Bex 2008

ork pldge, Tamaanea 37831-6131

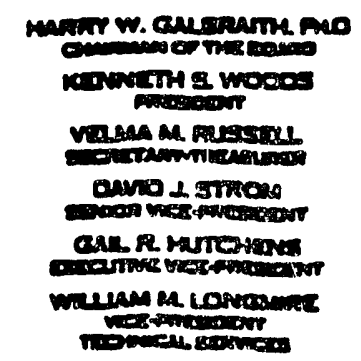

Stone 8, 1992

Recaived: Tune Ixt 808: 3658284

Denr Me. Fexgaros:

inalyeis of gorn comporend gavm the following zanitus:

Sowa ores $f$ andyeas,

Dine Eart mall $\$-3376$

- cacos

- Eydrogara

$<0.5$

8 silerer

sodirm

* Bagneasiom

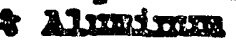

- silieara

- Potraneirm

- calcira

- Ires

- tisar

geris Dansity, $9 / m 1$

geronds/co. Et.

$<0.5$

0.10

0.21

0.31

2.33

39.26

1.18

7.29

1.28

$<0.077$

1.492

93.23

\begin{tabular}{|c|c|c|c|c|}
\hline 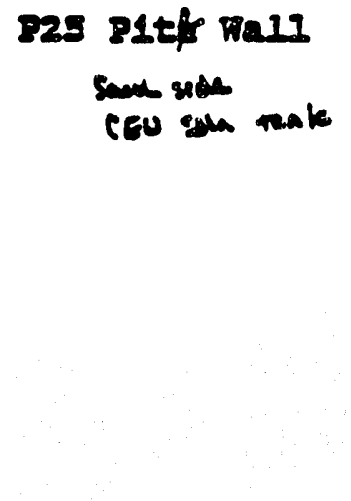 & $11-3377$ & 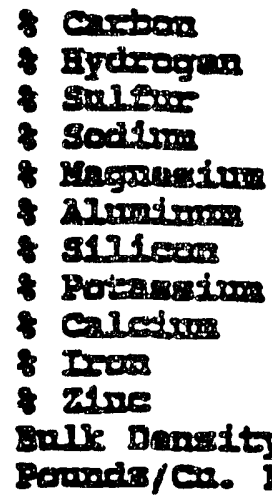 & 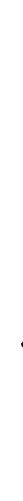 & $\begin{array}{l}<0.5 \\
<0.5 \\
10.08 \\
0.021 \\
0.27 \\
0.32 \\
4.45 \\
<0.054 \\
3.71 \\
0.70 \\
<0.06 \\
2.270 \\
141.72\end{array}$ \\
\hline
\end{tabular}

Fig. C.1. Analyses of concrete walls in Building 3019. 


\section{Mr. Marion Farguson \\ Page 2 \\ June 8, 1992}

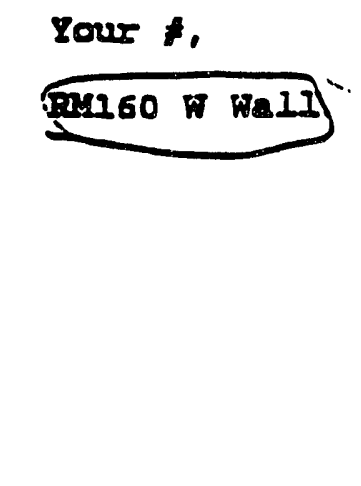

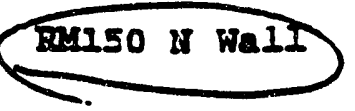

our $\$$

๓ -3378

w-3379
Analyser,

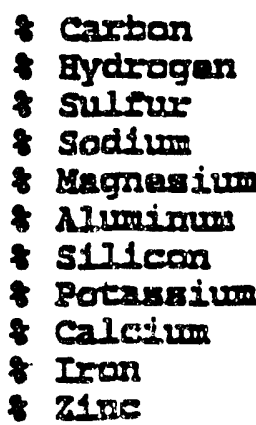

Bulk Dansity, $g / m l$ Pourads/Co. Ft.

$<0.5$

$<0.5$

0.10

0.27

0.34

2.37

38.46

0.90

7.65

1.70

$<0.074$

1.325

94.58

* Cacbar

- Eydragan

- sulfur

- Sodisim

- Magransium

* Alumimom

- 9111con

- Potansiura

* Calciam

- Iress

* Z150

Bulk Dansity, g/ml

Porosis/ Cas. Ft.
$<0.5$

$<0.5$

0.066

0.24

0.29

2.09

32.02

0.69

7.69

1.20

$<0.05$

1.562

97.52

sincaraly yours,

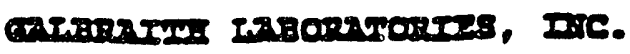

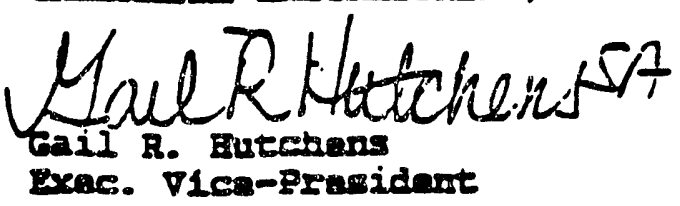

Gr:: 51 a

Fig. C.1 (continued). 


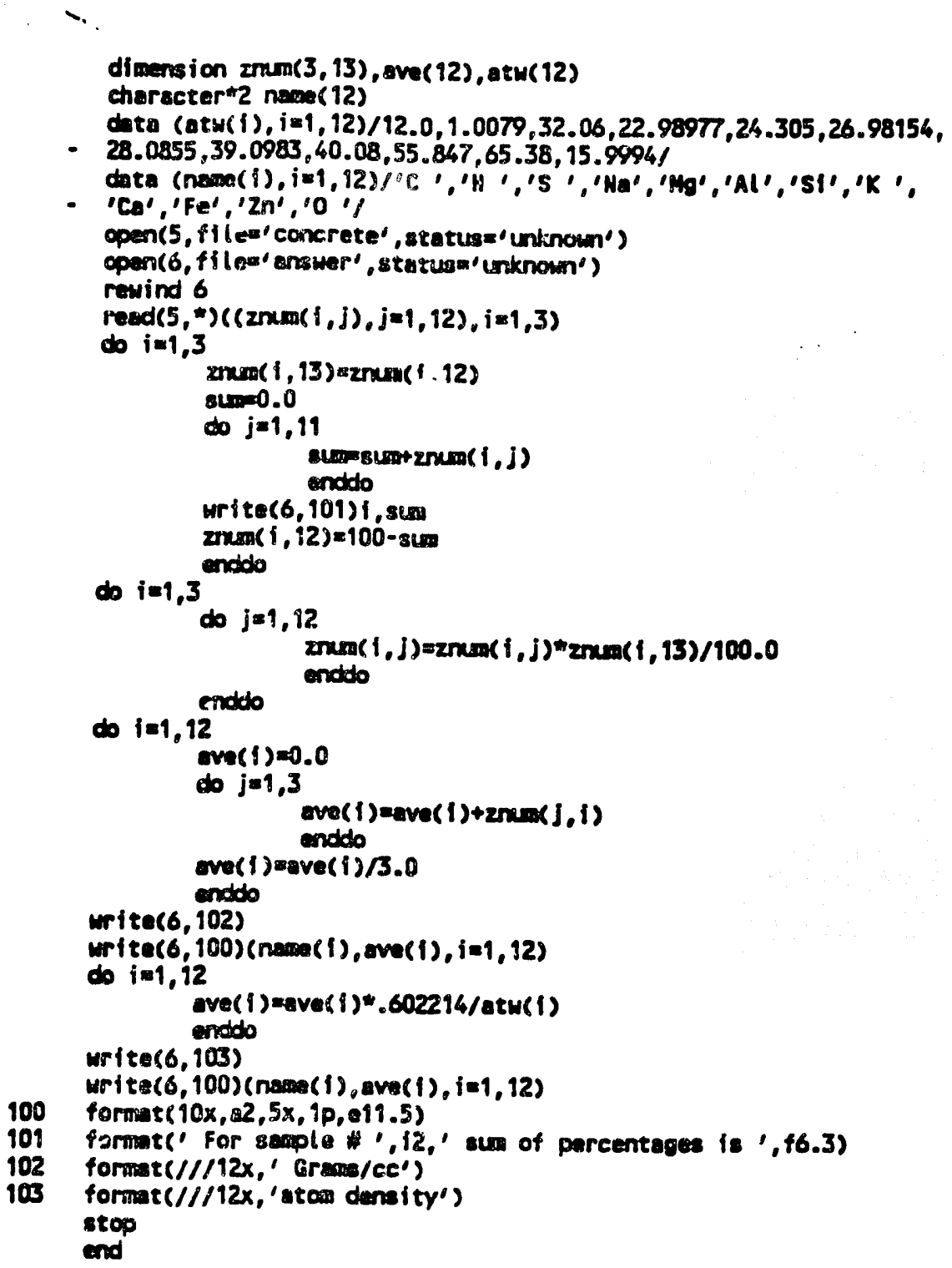

Fig. C.2. FORTRAN program to calculate atom densities for constituents of concrete. 
Fig. C.3. Input to FORTRAN program to calculate concrete atom densities.
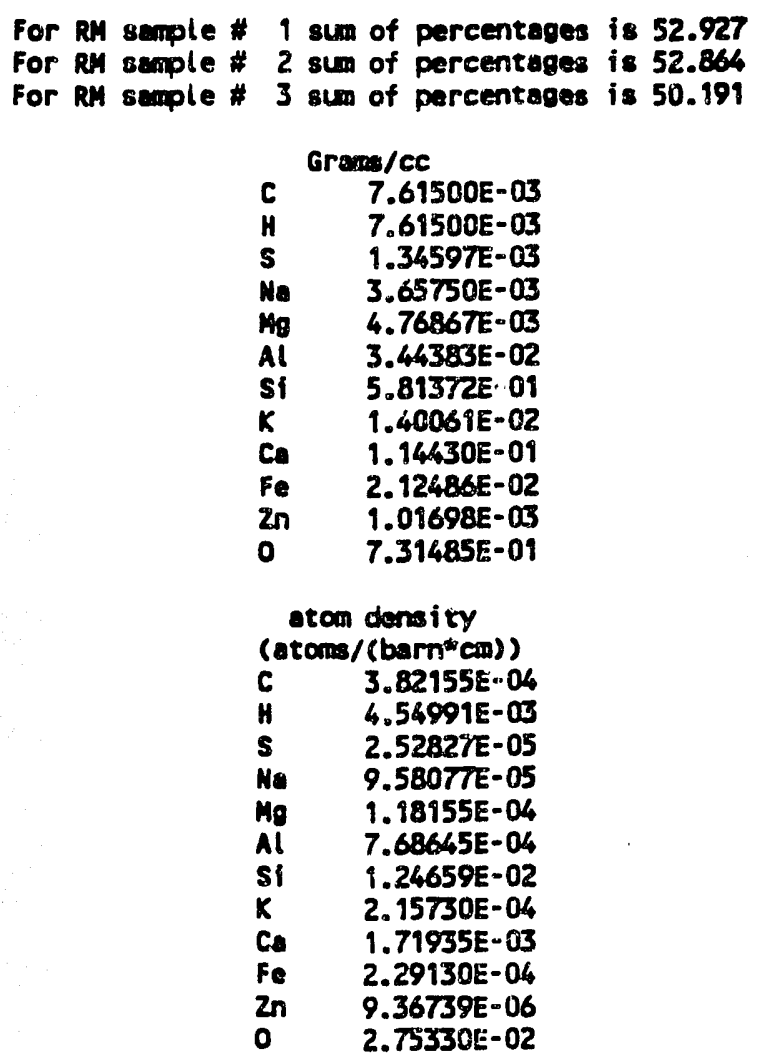

Fig. C.4. Output from FORTRAN program to calculate concrete atom densities. 


\section{APPENDIX D}

ASSUMPTIONS FOR SPECIFYING WATER CONTENT FOR MIXED OXIDE WASTE 
MARTIN MARIETTA ENERGY SYSTEMS, INC.

September 25, 1992

R.T. Primm, III

\section{Assumptions for specifying Water Content for NFS MOX Waste}

The following assumptions for water content in NFS MOX waste are appropriate for use in nuclear criticality safety evaluations for the indicated reasons:

1. Initial water content of material is less than $1 \%$. MOX waste will be subjected to heat treatment for the specific purpose of driving off moisture and volatile components. These treatments include heating to $600+/-25$ deg $C$ for 4 hours with cooldown and packaging in an inert atmosphere. The waste acceptance criteria for this material is actually $<0.2 \%$; however, the more conservative value $(<1 \%)$ may be assumed for these evaluations.

2. Water ingress into the primary container will be prevented during handling. Packaging will be performed within an inert atmosphere into a stainless steel container with a bolted, flanged closure. Bolts will be secured in a specified a sequence and to a specified torque ( $8 \mathrm{ft}-\mathrm{lbs})$ to ensure closure consistent with a 150 psig hydro-test procedure.

3. Water ingress into the primary container will be prevented during storage. Closed primary containers will be encased into a welded-shut overpack capsule prior to storage. Welding procedures and welders will be qualified and certified for use on this package. Welded closures will be visually inspected and subjected to dye penetrant testing to provide a quality control check of the weids.

Please call me if any additional information is needed on these assumptions.

Alan $m$ Kinch wisly

Alan M. Krichinsky, 3019 MS-6046 (4-6940) - RC

AMK:dsc

cC: B.D. Patton

C.E. Pepper

B.W. Starnes 
APPENDIX E

INTERPRETATIONS OF 1985 RESULTS 


\section{APPENDIX E}

\section{INTERPRETATIONS OF 1985 RESULTS}

Hopper has noted that the selected subcritical value of $k$-effective $<$ or $=0.93$ has little relevance to "margins of safety" without an understanding of the changes in k-effective with respect to changes in operational conditions. Consequently, a model was developed to relate operational values (material density, degree of moderation, geometry, etc.) to system reactivity. Thus operational parameters were related directly to safety limits.

Though the calculations reported in Table 5 are nonconservative, these analyses of them are presented as a model for future derivations. To interpret and interpolate from the computational results of Sect. 4 , an algorithm was used to relate fissile material density and cylinder radius to array reactivity for the considered materials. The behavior of the algorithm in predicting array reactivity was examined.

The following sections provide the development of the algorithm and interpolation of calculated results relevant to operational limits and variations for the storage wells.

\section{E.1 REACTIVITY AND PHYSICAL PARAMETERS OF THE WASTE MATERIAL}

It has been demonstrated (Refs. 1 and 2) that array reactivity can be related to array unit mass/reactivity for uniform arrays of fissile material even with the presence of interunit moderating and absorbing materials. That is to say, the array and unit reactivities are proportional to the unit mass (i.e., k-eff $\propto$ (Unit Mass) $^{1 / 3}$. For near-infinite-length cylindrical units of variable density and geometry, the mass per unit length or reactivity can be expressed as a relation with density:

$$
\text { Array k-eff }=(\mathrm{A} 1)^{*}(\text { Material Density })^{1 / 3}+\mathrm{B} 1 \text {, }
$$

or to geometry,

$$
\text { Array } k \text {-eff }=(\mathrm{A} 2)^{*}(\text { Material Radius })^{2 / 3}+\mathrm{B} 2 \text {, }
$$

where A and B are constants of proportionality. Where both the material density and geometry vary, the array reactivity may be expressed as

$$
\begin{aligned}
\mathrm{k} \text {-eff } & =(\mathrm{A} 3)^{*}\left[(\text { Material Density })^{1 / 3}\right] \\
+ & (\mathrm{B} 3)^{*}\left[(\text { Material Density })^{1 / 3}\right]^{*}\left[{\text { (Material Radius } \left.)^{2 / 3}\right]}\right. \\
+ & (\mathrm{C} 3)^{*}\left[{\text { (Material Radius } \left.)^{2 / 3}\right],}\right.
\end{aligned}
$$

where A3, B3, and C3 are combined constants of proportionality. 
This last relationship was used to interpret intermediate KENO V.a search results to interpolate variable loading conditions (material densities and radii) having equivalent array reactivities. A multiple linear regression fit of this relationship to the results of Table 5 reproduces the KENO calculated results between $k$-effs of 0.88 and 1.02 with a standard deviation of about $1 \%$ for the range of variables considered. Figure 5 is a scatter graph of the deviation between $k$-effs predicted by the above relationship and about 300 KENO calculated k-effs between the values of 0.88 and 1.02 . Note that the values which fall above and below the two standard deviation values are not unique to a specific material or storage configuration.

Combined constants of proportionality (multiple linear regression coefficients) for the considered materials are presented in Table D. 1 for Intercell 2 and 3.

Table E.1. Fitted constants of proportionality for ${ }^{239} \mathrm{Pu}$ in Intercell 2 and 3

\begin{tabular}{|c|c|c|c|c|}
\hline \multirow{2}{*}{ Material form } & \multirow{2}{*}{$\begin{array}{c}|c| \\
\text { atom ratio }\end{array}$} & $\mathbf{A 3}$ & $\mathbf{B 3}$ & $\mathbf{C 3}$ \\
\cline { 3 - 5 } & 0 & -0.10970477 & 0.32883389 & -0.17464236 \\
\hline Metal & 1 & -0.14458998 & 0.36506649 & -0.19289005 \\
\hline Oxides & 3 & -0.22096846 & 0.41614497 & -0.18779307 \\
\hline & 10 & -0.26247951 & 0.49957564 & -0.18691215 \\
\hline & 20 & -0.18640133 & 0.59263783 & -0.24259676 \\
\hline
\end{tabular}

\section{E.2 INTERPOLATIONS OF SUBCRITICAL FISSILE MATERIAL MASS LOADINGS}

The relationship in Sect. D.1, with the associated coefficients, predicts the calculated values with a , standard deviation of about $1 \%$ in $k$-eff for the range of intended application (i.e., k-effs between 0.90 and 0.96). It is judged from Appendix $A$ that a calculated $k$-eff plus 2 standard deviations which is less than 0.93 may be considered subcritical for the materials evaluated.

Figure 5 is a graph that was generated using the algorithm presented in Sect. D.1 such that the plotted loadings would have a predicted $\mathrm{k}$-eff of 0.93 . It depicts fissile material linear mass loadings vs fissile isotope density. Note that all the limiting values presented in Fig. 6 are significantly less than the single unit subcritical values provided in Table 6. If one ignores the cell wall concrete composition, then the predicted "safe" linear Pu density at 0.2 wt \% water ( $\mathrm{H} / \mathrm{Pu}$ ratio of 0.05$)$ - corresponding to NFS waste is $10 \mathrm{~kg} \mathrm{Pu} / \mathrm{ft}$. Furthermore, if one assumes, as recommended in Sect. 5, that $\mathrm{U}-238$ be treated as ${ }^{239} \mathrm{Pu}$, then the limit is $2 \mathrm{~kg} \mathrm{Pu} / \mathrm{ft}$. This is approximately 4 times larger than the expected value of $0.48 \mathrm{~kg}$ $\mathrm{Pu} / \mathrm{ft}$, allowing a sufficient margin for the more reactive, Appendix $\mathrm{C}$ concrete composition. 


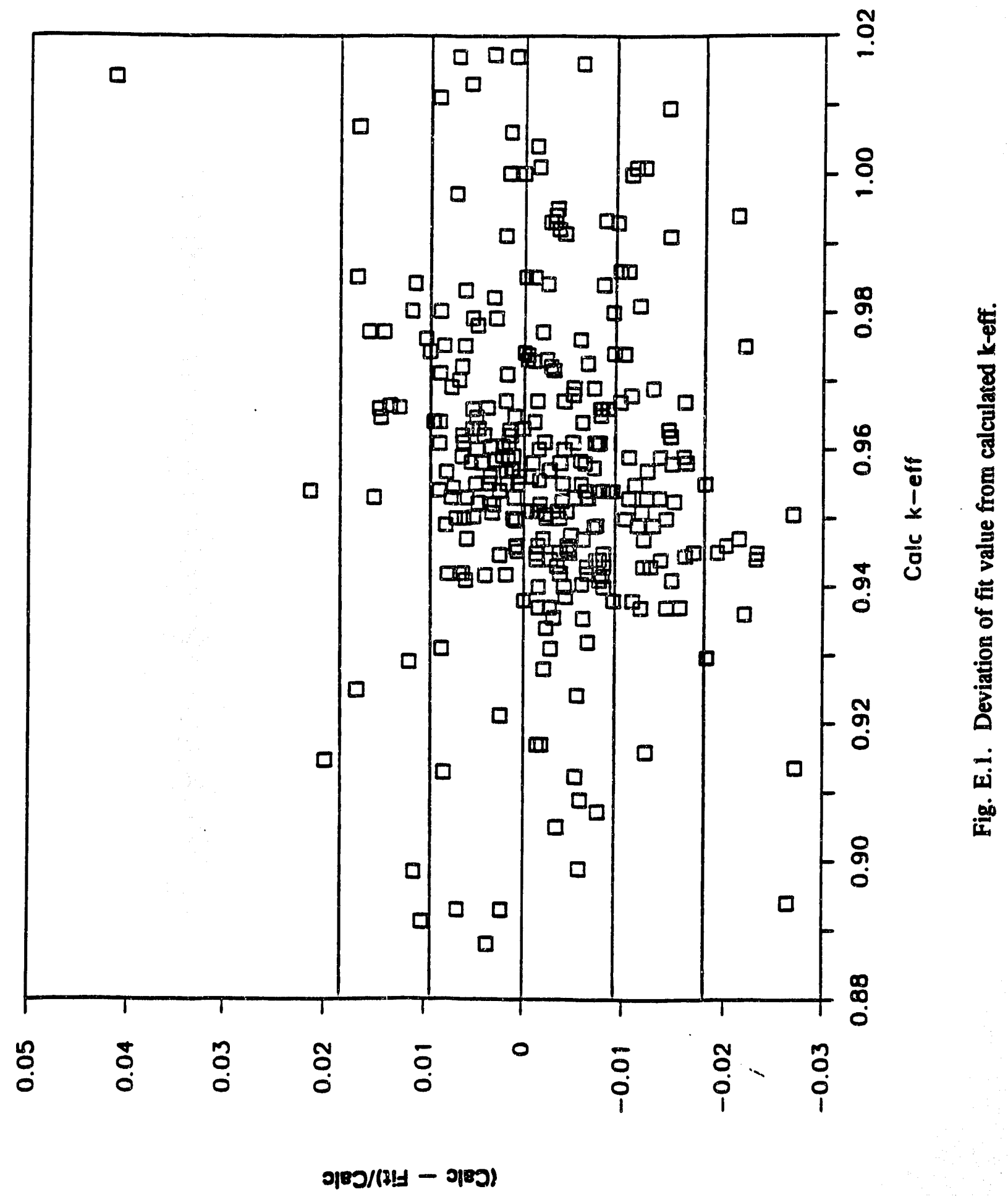




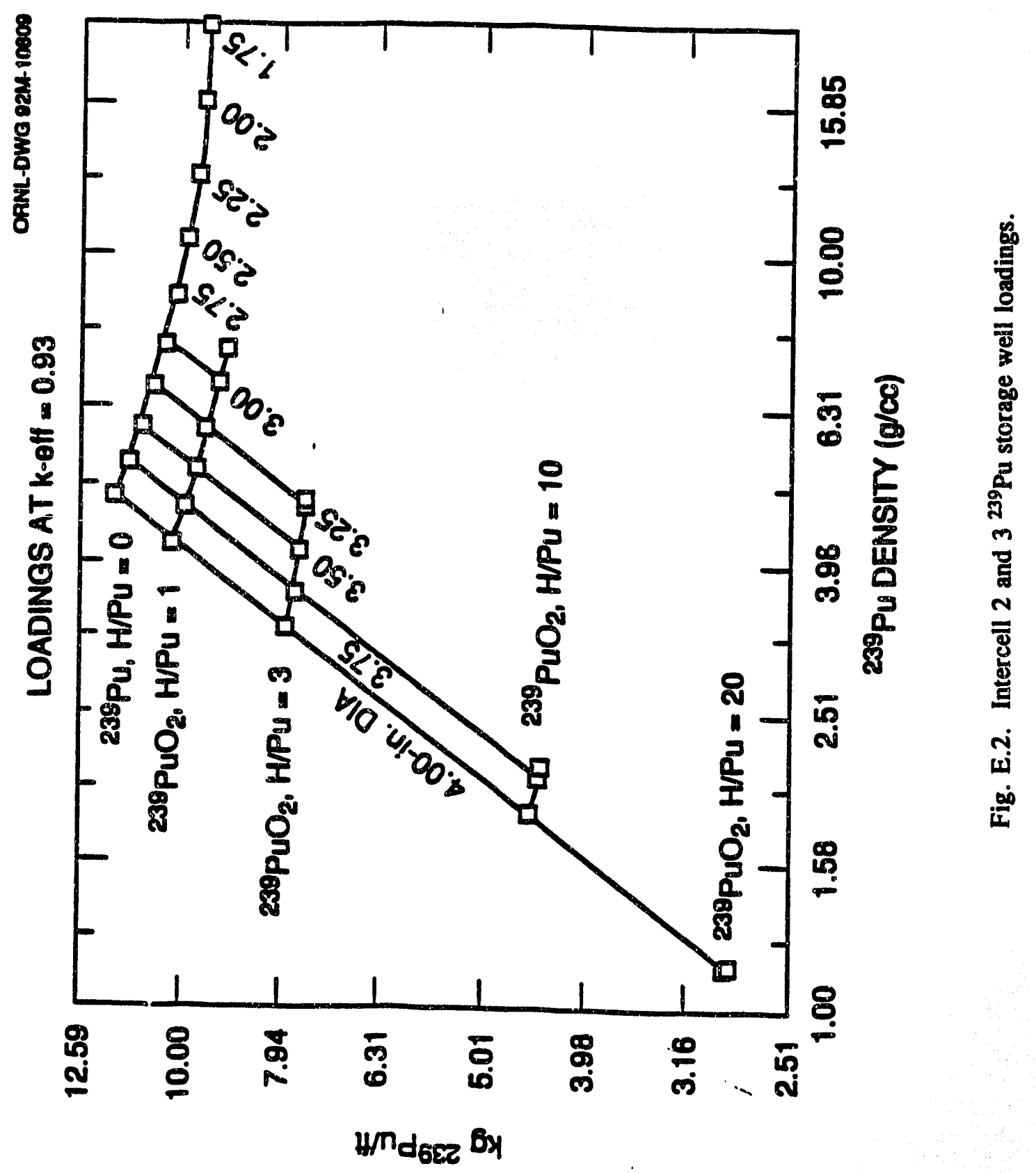




\section{REFERENCES FOR APPENDIX E}

1. J. T. Thomas, "Review of Criteria for Nuclear Criticality Safety Control in Transportation," in Proceedings of the Fifth International Symposium on Packaging and Transportation of Radioactive Materials, Las Vegas, Nevada, May 7-12, 1978.

2. J. T. Thomas, "Generic Array Criticality," Y-CDC-13, Union Carbide Corporation-Nuclear Division, Y-12 Plant, Oak Ridge, TN, August 1, 1973. 


\begin{abstract}
APPENDIX F
SCALE INPUT FOR "NORMAL" OPERATION OF NFS WASTE STORAGE IN INTERCELL 2 AND 3 WELLS
\end{abstract}




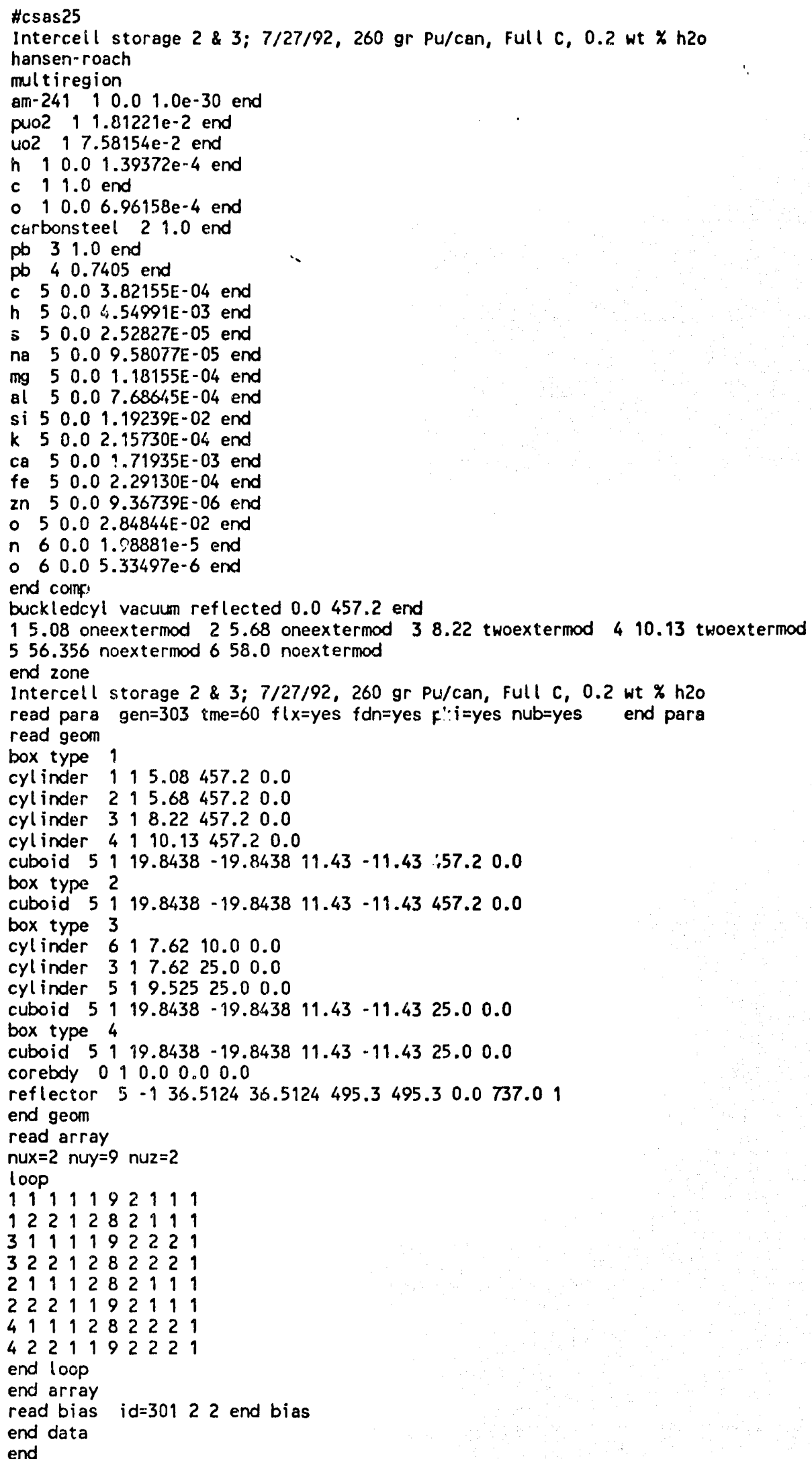




\section{INTERNAL DISTRIBUTION}

1. H. L Adair

2. J. E. Bigelow

3. S. D. Clinton

4. E. C. Crume, Jr.

5-6. H. L. Dodds

7. H. R. Dyer

8. P. B. Fox

9. R. K. Genung

10-14. C. H. Hopper

15. D. T. Ingersoll

16. W. C. Jordan

17. G. Q. Kirk

18-19. A. M. Krichinsky

20. N. F. Landers

21. R. D. Lawson

22. K. H. Lin

23. P. E. Mueller

24. C. V. Parks

25. B. D. Patton
26. W. H. Pechin

27-28. C. E. Pepper

29. L. M. Petrie

30-34. R. T. Primm, III

35-39. G. R. Smolen

40. S. G. Snow

41. B. W. Starnes

42. D. W. Turner

43. J. C. Turner

44. R. C. Ward

45. R. M. Westfall

46. G. E. Whitesides

47-51. B. A. Worley

52. EPMD Reports Office

53-54. Laboratory Records Dept.

55. Laboratory Records, ORNL-RC

56. Document Reference Section

57. Central Research Library

58. ORNL Patent Section

\section{EXTERNAL DISTRIBUTION}

59-60. Office of Scientific and Technical Information, P.O. Box 62, Oak Ridge, TN 37831.

61. Office of Assistant Manager for Energy Research and Development, Department of EnergyOak Ridge Field Office, P.O. Box 2008, Oak Ridge, TN 37831.

62. Professor Roger W. Brockett, Harvard University, Pierce Hall, 29 Oxford Street, Cambridge, MA 02138.

63. Dr. James E. Leiss, Rt. 2, Box 142C, Broadway, VA 22815.

64. Professor Neville Moray, Dept. of Mechanical and Industrial Engineering, University of Illinois, 1206 West Green Street, Urbana, IL 61801.

65. Professor Mary F. Wheeler, Department of Mathematics, Rice University, P.O. Box 1892, Houston, TX 77251. 

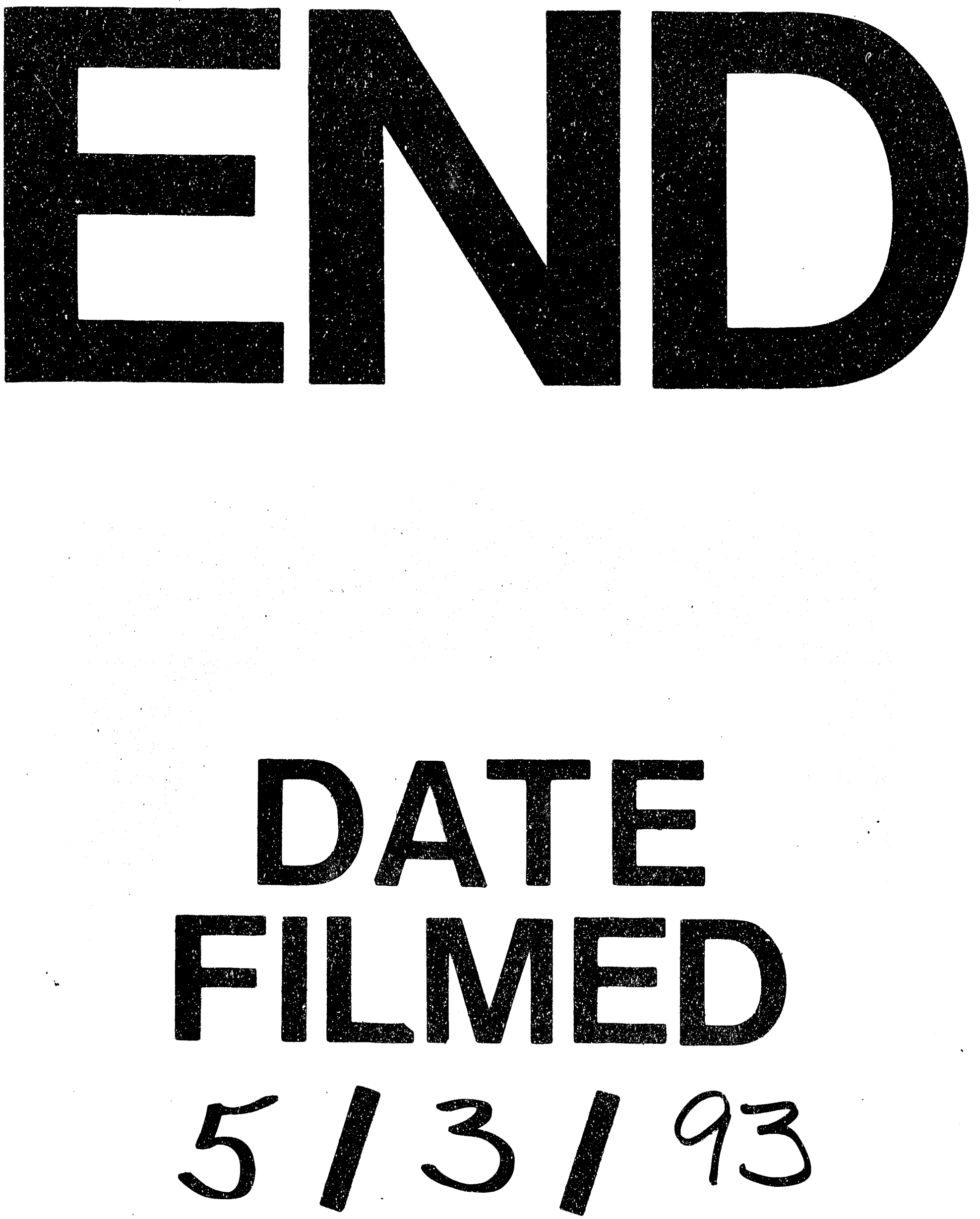
